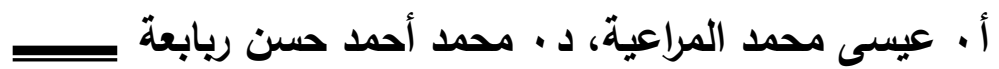
الصورة الذهنية للمعلم لاى الجمهور الأردني دراسة ميدانية

أ . عيسى محمد المراعية (")

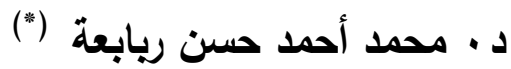

المقدمة :

الحمد لله رب العالمين، والصلاة والسلام على سبدنا محدد وعلى آله : وصحبه أجمعين، وبعد؛

فلا شكّ أنّ المعلم من أسمى القدوات في المجتمع وأرقاها، وعليه تتهض الته العمليّة التربوية والتعليمية؛ فعلى عاتقه تقع مهمة تتفيذ المنهاج وتهيئة البيئة التعليمية الني تجعل الطالب قادراً على اكتساب المعرفة، كما أن للمعلم دوراً كبيراً في تتمية مهارات الطلبة وإعدادهم للحياة. وعلى الرغم من علو مكانة المعلم فإن ثلك المكانة بدأت تتغير بفعل العديد

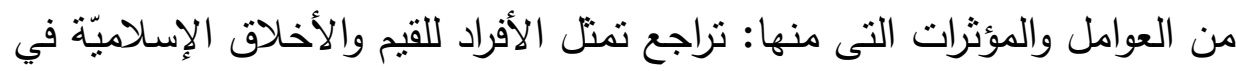

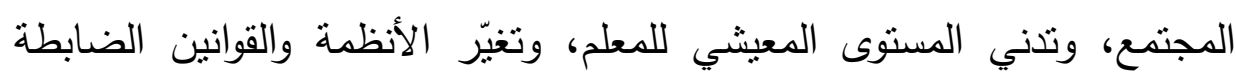

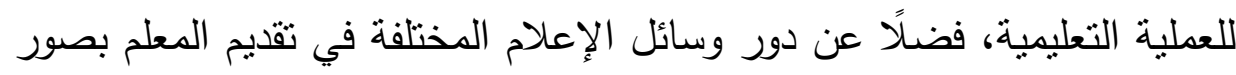
تقليدية أو صور منتقدة، وغير ذلك مما أسهم في تراجع هيبة المعلم وتغيّر

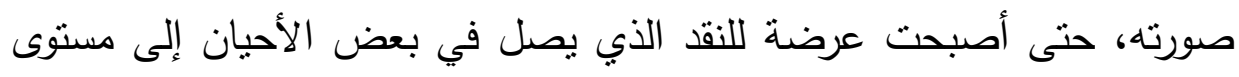

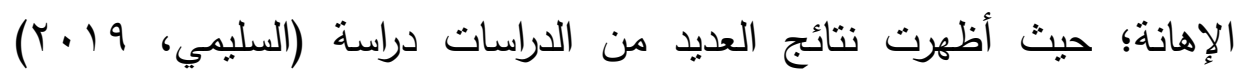

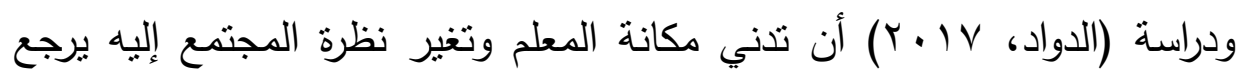

باحث في مرحلة الدكتوراه - التربية الإسلامية - قسم الدراسات الإسلامية -

$$
\text { جامعة اليرموك. }
$$$$
\text { (" أستاذ مشارك في الإعلام - الإعلام الإنسلامي - جامعة اليرموك - الأردن. }
$$ 


\section{الصورة الذهنية للمعلم}

بالأساس إلى ضعف الوضع المادي للمعلم، والصراع القيمي في المجتمع، وقلة

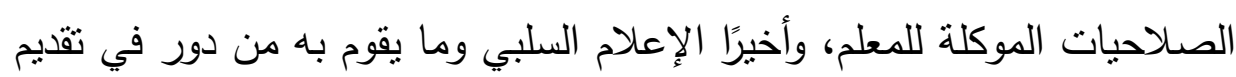

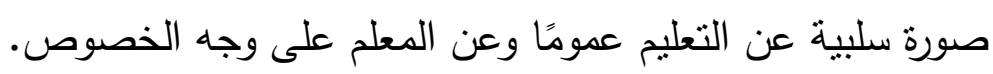

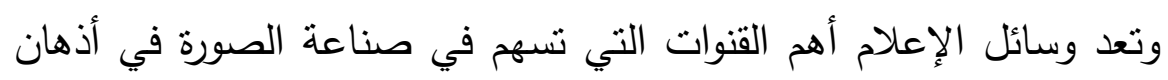

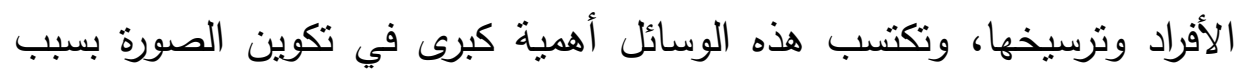

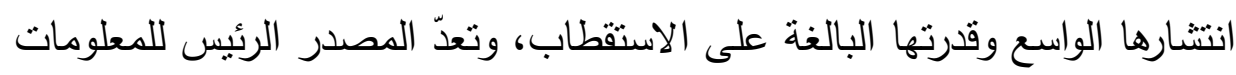

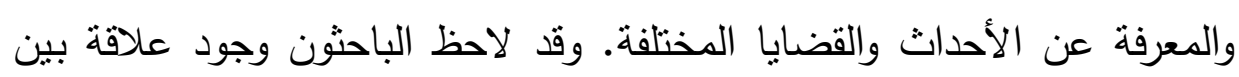
الصورة الذهنية والاتجاهات حين تتبلور وتكتمل بشكل تتتاسب فيه مع اتجاهات الأفراد تكاد حينها تفتقد خاصيتها الديناميكية وتكون صعبة التغير • (عجوة، .) (19人r

وتختلف الصورة الذهنية للمعلم باختلاف طبيعة المجتمعات، وإن كانت

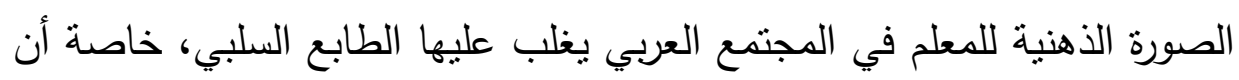

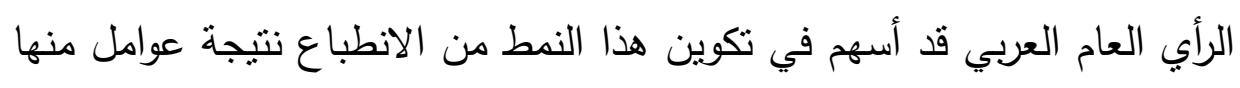

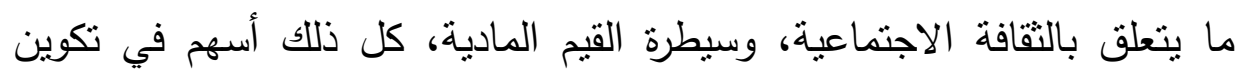

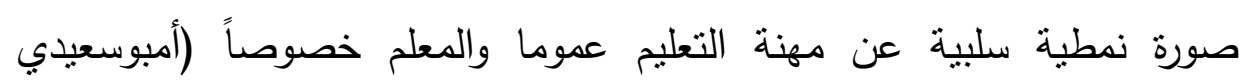

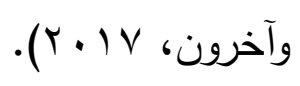

وقد شهر الفضاء الإعلامي في الأردن في الآونة الأخيرة في المواد والبرامج

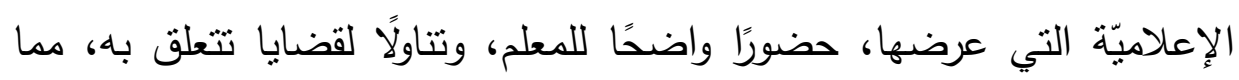

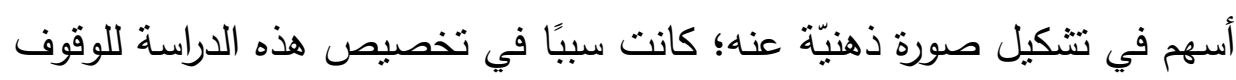

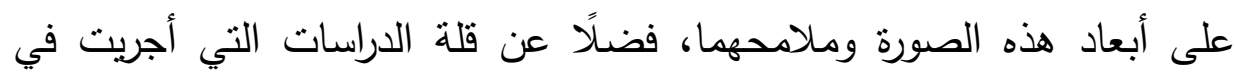

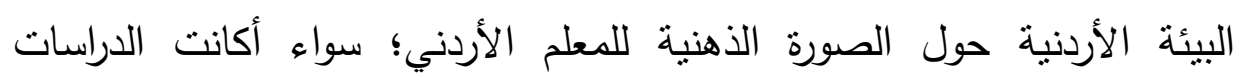

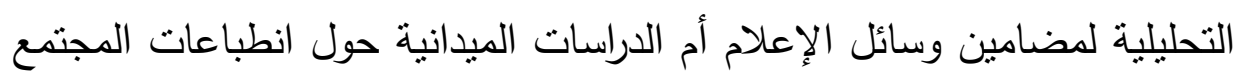
الأردني حول صورة المعلم، ولذا فقد جاءت هذه الدراسة لبيان الصورة الذهنية 


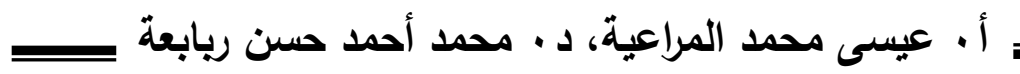

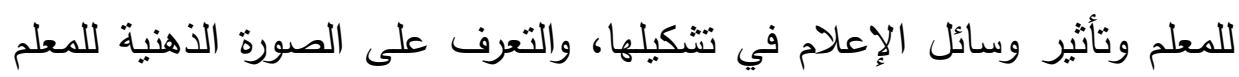
لاى أفراد المجتمع الأردني الواقعي.

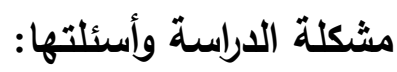

تتمحور المشكلة الرئيسة للدراسة في محاولة التعرف على الصورة الذهنيّة

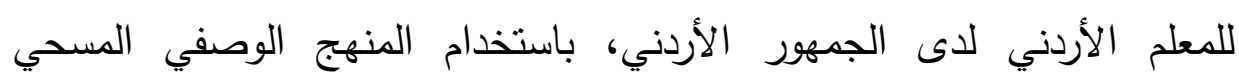

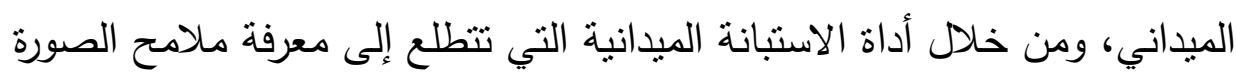
الذهنية المرتسمة لاى الجمهور الأردني عن المعلم. وتتلخص مشكلة الدراسة حول السؤال الرئيس التالي:

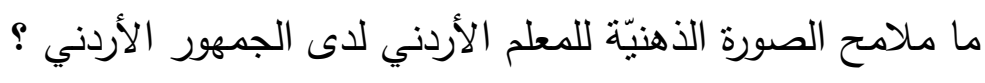

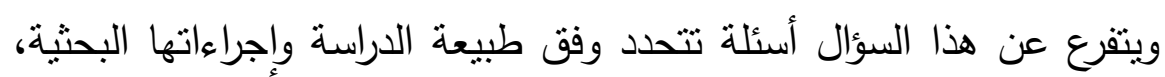
وفيما يلي أسئلة الدراسة المتفرعة عن هذا السؤال الرئيس:

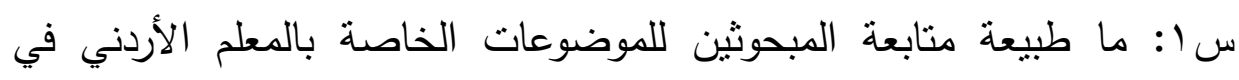

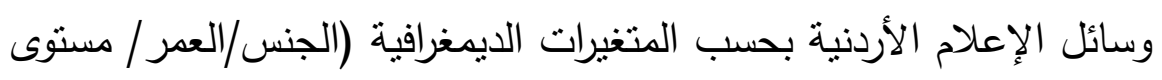

$$
\text { التعليم)؟ وسيأل }
$$

س r: ما ملامح الصورة الذهنية العامة عن المعلم الأردني لدى الجمهور الأردني بحسب المتغيرات الديمغرافية (الجنس/العمر / مستوى التعليم)؟

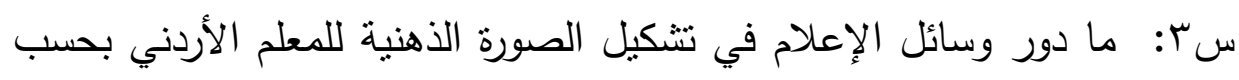
المتغيرات الديمغرافية (الجنس/العمر / مستوى التعليم)؟

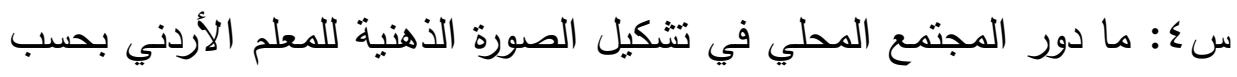
المتغيرات الديمغرافية (الجنس/العمر / مستوى التعليم)؟ 


\section{الصورة الذهنية للمعلم}

أهداف الدراسة:

تهذف هذه الدراسة في إطارها العام إلى بيان الصورة الذهنيّة للمعلم الأردني

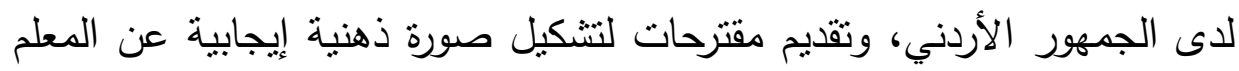

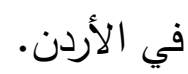

ويتفرع عن هذا الهدف العام جملة أهداف فرعية، وفيما يأتي بيان ذللك:

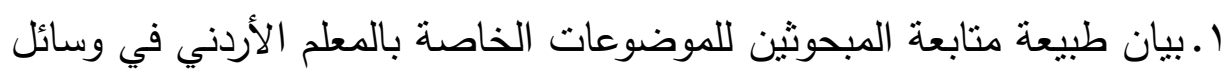
الإعلام الأردنية بحسب المتغيرات الديمغرافية (الجنس/العمر / مستوى التعليم).

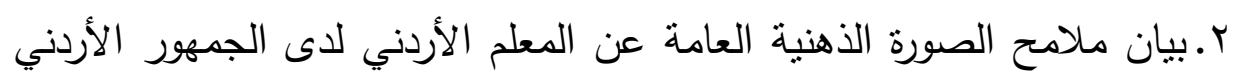
بحسب المتغيرات الديمغرافية (الجنس/العمر / مستوى التعليم).

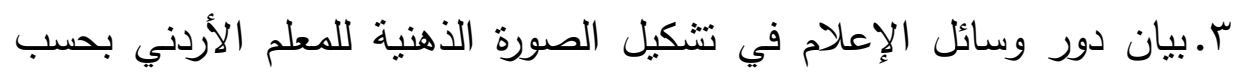
المتغيرات الديمغرافية (الجنس/العمر / مستوى التعليم).

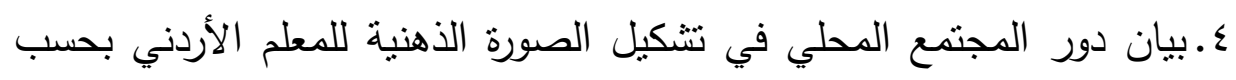
المتغيرات الديمغرافية (الجنس/العمر / مستوى التعليم).

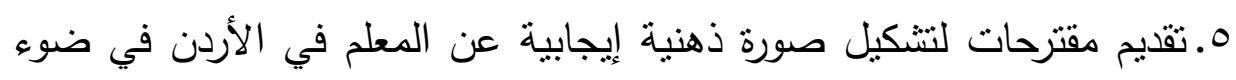
نتائج الدراسة.

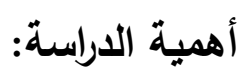
تتمنل أهمية الدراسة في بيان دور وسائل الإعلام في تكوين الصورة عن المعلم وملامح تلك الصورة وما لذلك من دور حيوي في التأثير على اتلى التاهات

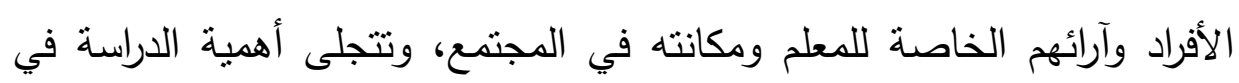
نقاط عدة، منها: 1.رفد المكتبة العلمية بدراسة نوعية غير مسبوقة في إطار إجرائها، وفي حدود

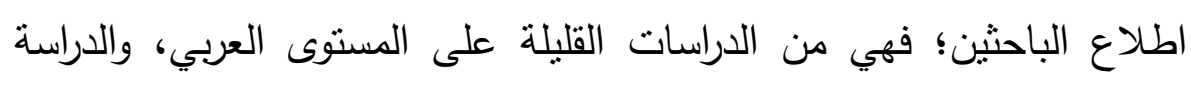

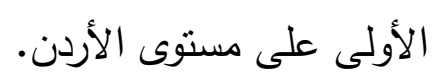




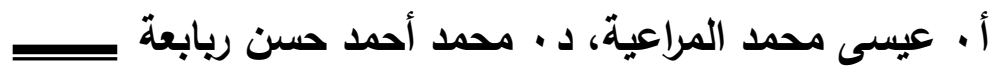

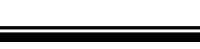

r.تقديم نتائج علمية تستقيد منها مؤسسات الدولة المعنية بتطوير التعليم ووضع سياساته العامة والخاصة بالمعلم، وبالأخص وزارة التربية والتعليم، وذلك من خلال ما تقدمه من نتائج حول ملامح الصورة الذهنية للمعلم لدى الجمهور الأردني.

r.تستقيد منها مؤسسات الإعلام الرسمي والخاص في تطوير خطابها الإعلامي الخاص بالمعلم وتقوبم خلله وتعزيز حسنه بما بخص تقديم صورة ذهنية

$$
\text { إيجابية عن المعلم. }
$$

التعريفات الإجرائية لمصطلحات الدراسة:

من أبرز المصطلحات التي اشتملت عليها الدراسة ما يلي: الصورة الأهنية: يُقصد بها في هذه الدراسة الانطباعات التي تتكون في أذهان أفراد المجتمع الأردني تُجاه المعلم الأردني، بناء على تصورات أو تجارب أو مواقف أو مضامين إعلامية ذات علاقة بالمعلم الأردني. وتقاس في هذه الدراسة من خلال الاستبانة التي تم إعدادها لهذا الغرض.

المعلم: الشخص الذي يتولى مهنة التربية والتعليم في أية مدرسة تتبع للبيئة

$$
\text { التربوبة التعليمية في الأردن، سواء أكانت مدارس خاصة أم حكومية. }
$$

وسائل الإعلام: هي الوسائل التي تتقل للجماهير المضامين والرسائل المختلفة، وقد تكون وسائل مقروءة أو مسموعة أو مرئية، على الصعيد المحلي

حدود الاراسة:

$$
\text { اقتصرت الدراسة الحالية على الحدود الآتية: }
$$

الحدود البثرية: تتحدد هذه الدراسة بالجمهور الأردني لبيان الصورة

$$
\text { الذهنية لديهم عن المعلم. }
$$

الحدود الزمانيّة: تتحدد هذه الدراسة بالفصل الدراسي الأول من العام

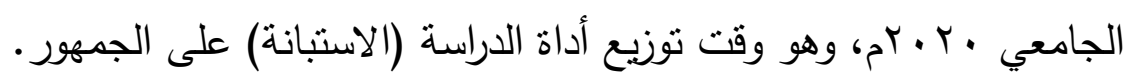




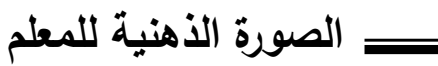

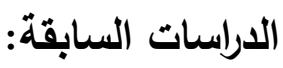

حرص الباحثان على مراجعة قواعد البيانات المحلية والعربية وتمكنا من

الحصول على بعض الدراسات ذات العلاقة بالدراسة الحالية، ومن تلك الدراسات:

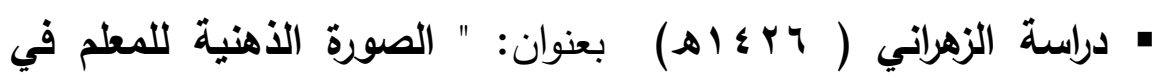

الصحافة السعودية دراسة تحليلية مقارنة خلال عثرين عاما"؛ حيث نت تحليل محتوى صحف الرياض وعكاظ وصحيفة اليوم، وقد خلصت الدراسة إلى جملة

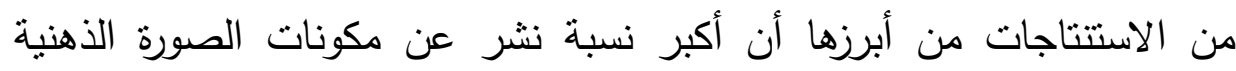

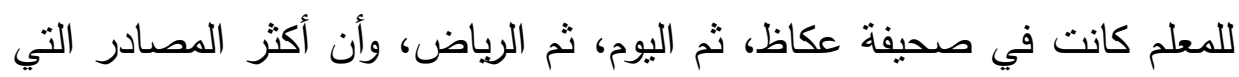

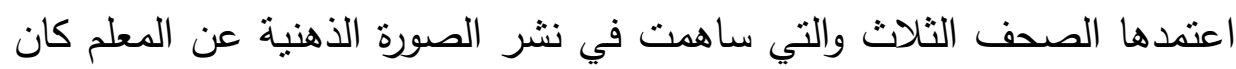
مصدرها المسؤول، ثم الدرر الصحفي، ثم كاتب الرأي، وأخيرا كان الاهتمام بحقوق المعلم المهنية وكذلك واجب المعلم تجاه الطالب. • دراسة سارة ( 10 ب ب) بعنوان: "صورة المعلم في المجتمع الجزائري":

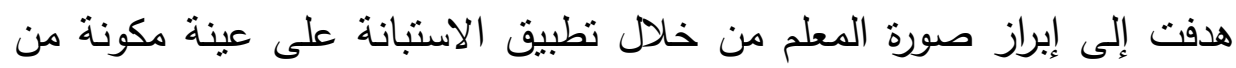

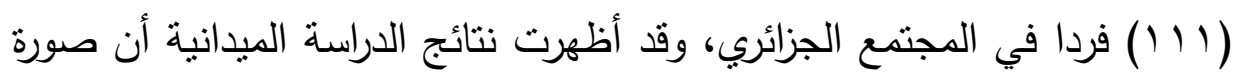
المعلم من وجهة نظر أفراد العينة كانت سلبية بسبب هندام المعلم وتكوينه المهني

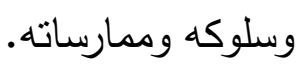

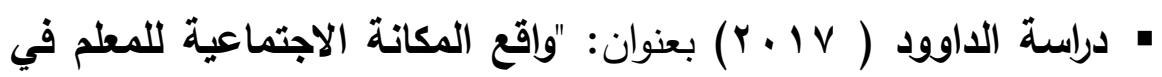
ثقافة المجتمع السوري من وجهة نظر المعلمين أنفسهم دراسة ميدانية في مدينة الحسكة": ولتحقيق هدف الدراسة تم اختيار عينة مكونة من (ع ؟Y) معلمًا ومعلمة صف، وتم تطبيق الاستبانة عليهم، وأظهرت النتائج أن المكانة

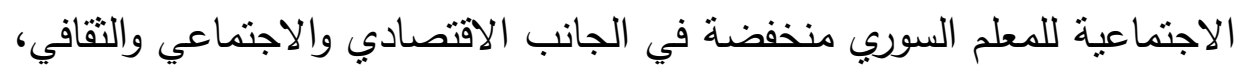
ومتوسطة في الجانب الثخصي. 


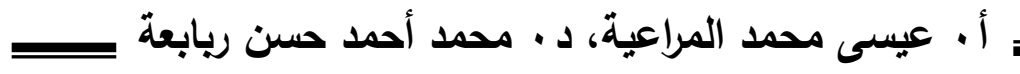

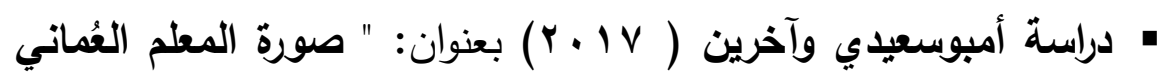

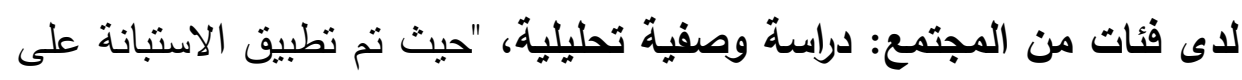

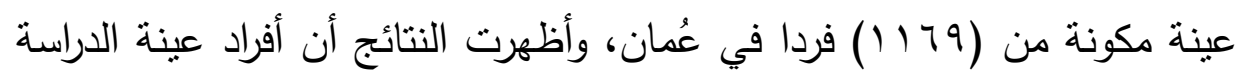

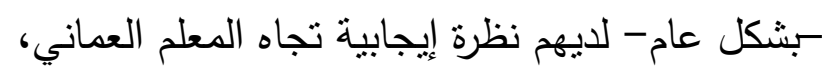

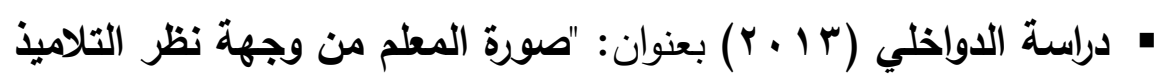

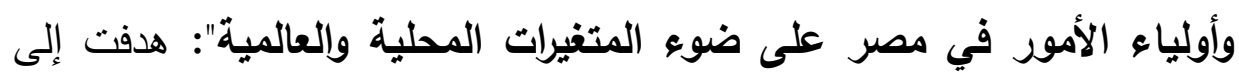

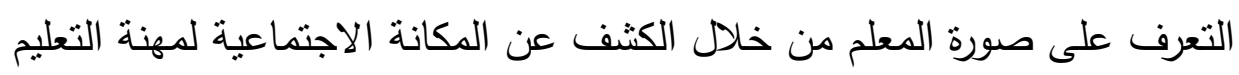

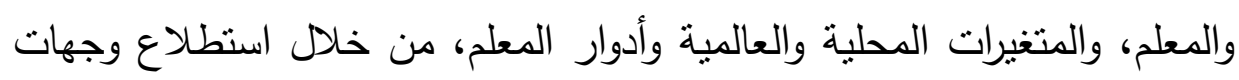

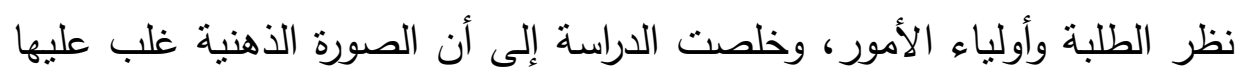

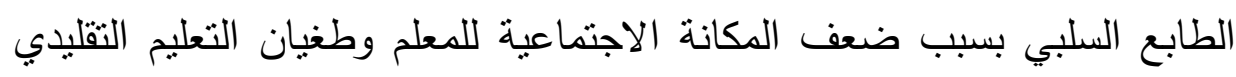
دون النظر إلى التغيرات العالمية التي حصلت على أدوار المعلم.

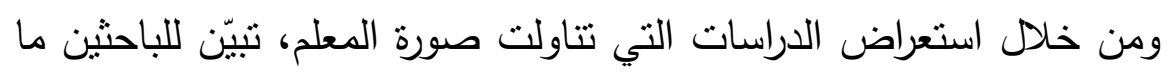

• إنّ الدراسات الميدانية الخاصة بصورة المعلم قد طُبقت في بيئات خارجية

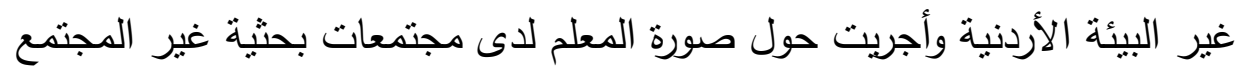

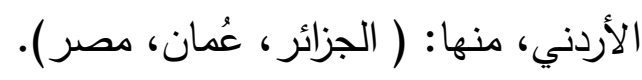

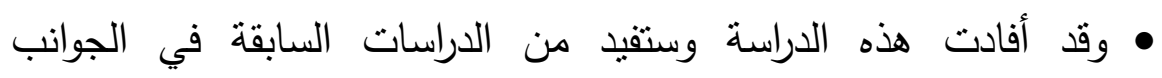

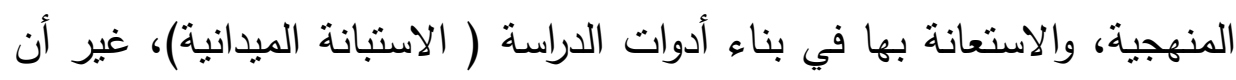

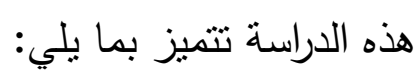
• تعد هذه الدراسة الأولى والسابقة في دراسة الصورة الذهنية عن المعلم

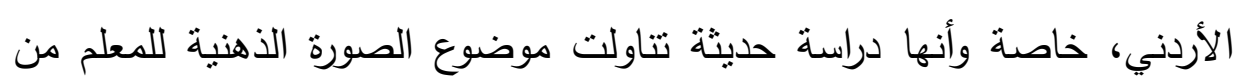

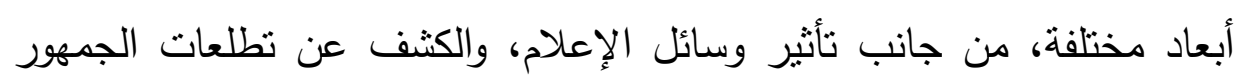
الأردني وما يحمله من صور ذهنية للمعلم الأردني.

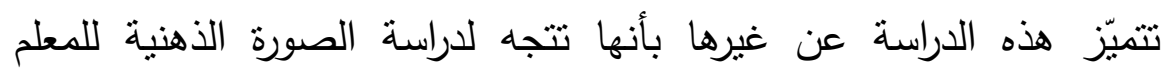
الأردني لاى الجمهور الأردني. 


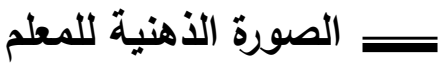

\section{الإطار النظري}

يتضمن هذا الجزء من الدراسة عرضا للمفاهيم النظرية التتعلقة بالصورة الذهنية، من حيث: مفهومها وأبرز خصائصها ومكوناتها ومراحل تكوينها، وإبرازًا

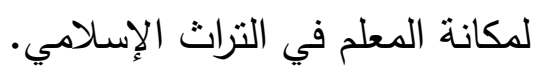

أولاً: الصورة الذهنية؛ مفهومها وخصائصها ومكوناتها ومراحلها:

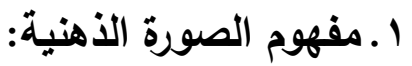

يُعد تحديد المفهوم أحد أهم مرتكزات البحث العلمي، ويعني هذا الاصطلاح

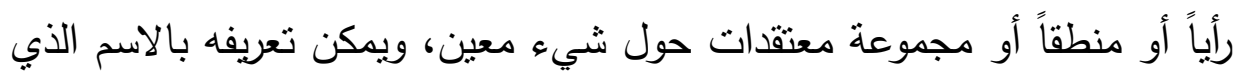
يطلق على الأثياء التي هي من صنف واحد، أو الذي يطلق على الصنف نفسهاء

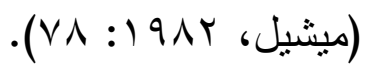

وتدور حول تحديد مفهوم الصورة الذهنية مناقثات فلسفية متعددة وكثيرة، وتحتل محوراً رئيساً في الفلسفة الحديثة بسبب كونها نقطة الانطلاق الفلسفي في تحديد مصادر الفكر البشري ومقاييسه، كما في نظريات الاستذكار الأفلاطونية

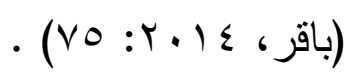

وتعرف الصورة الذهنية: بأنها تمثيل عقلي لثيء ما دون وجود لمؤثرات

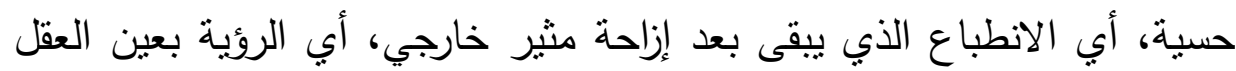

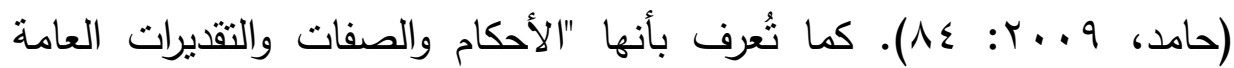

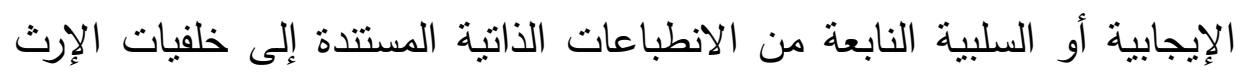

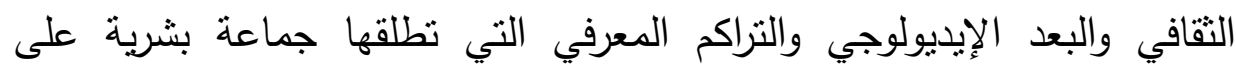
جماعة أخرى أو كيان جماعي نتيجة الأحكام المسبقة التي تحملها حولها، ولذلك الكئل

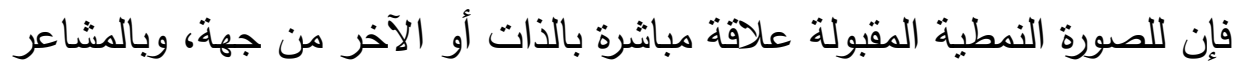
الكتاقضة: العنف والتسامح والاتصال والقطيعة والحب والبغض والتمويه والحقيقة

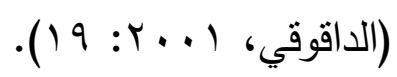




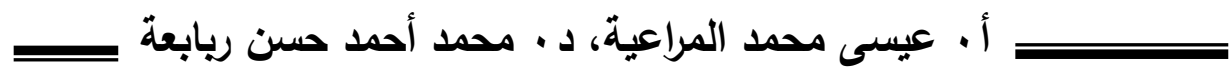
وتتميز الصورة الذهنية بخصائص عدّة، منها: عدم الدقة؛ لأنها لا تعبر

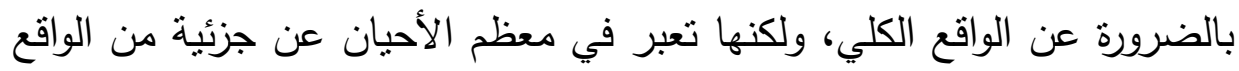

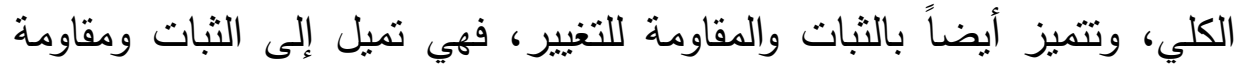

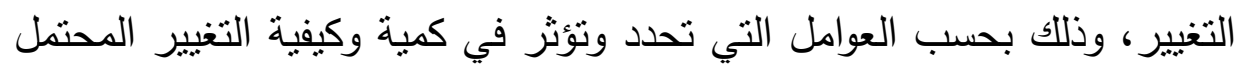

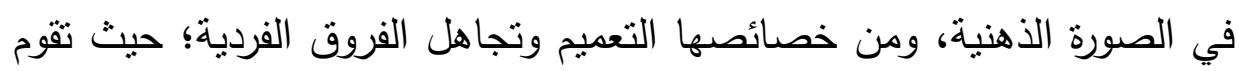

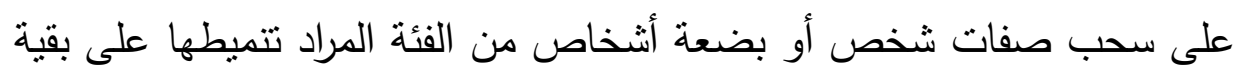

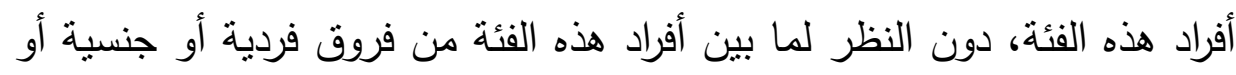

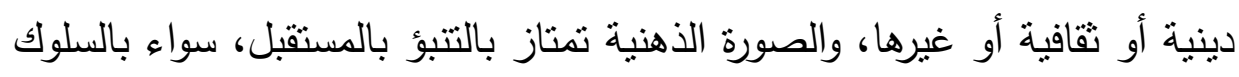

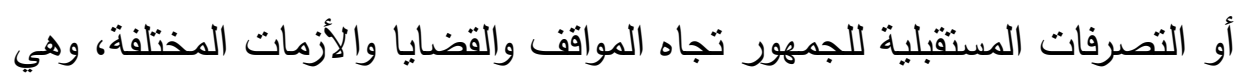

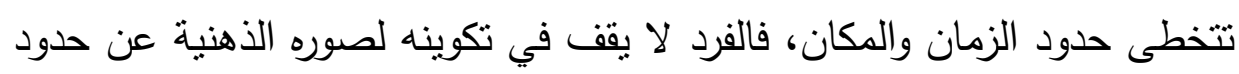

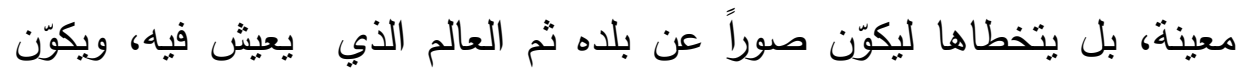

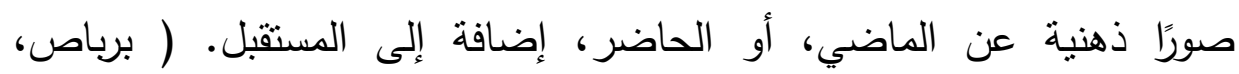
$(\varepsilon \cdot: r \cdot T$

وهناك ثمة علاقة بين الصورة الذهنية والصورة النمطية أو المقولبة؛ فبينهما

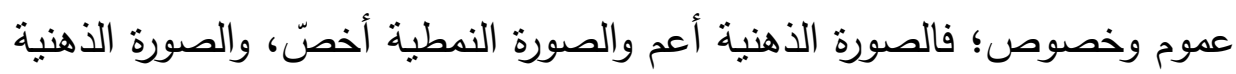

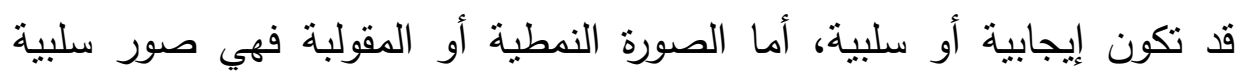

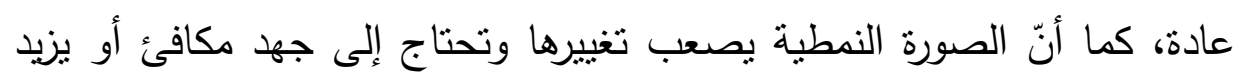

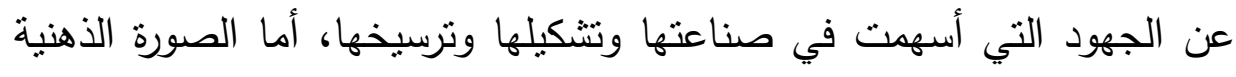

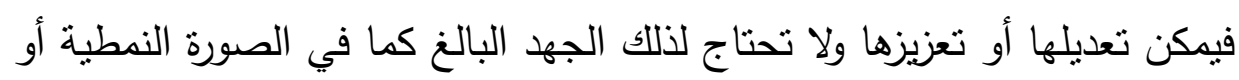

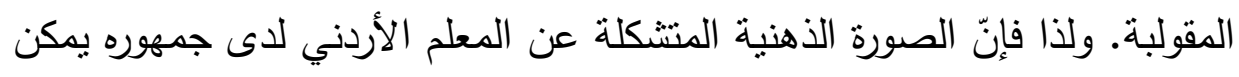

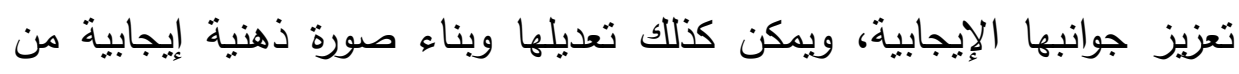

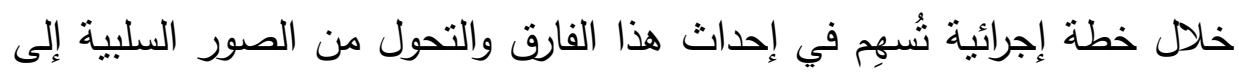

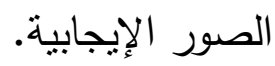




\section{=}

r. براحل تكون الصورة الذهنية:

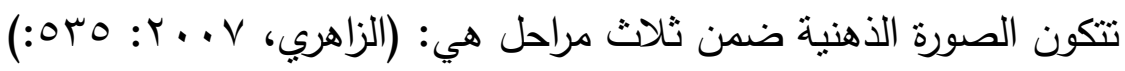

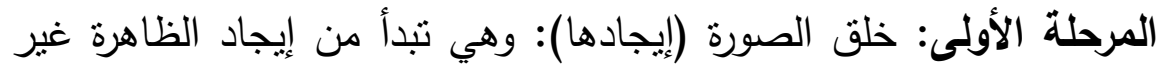

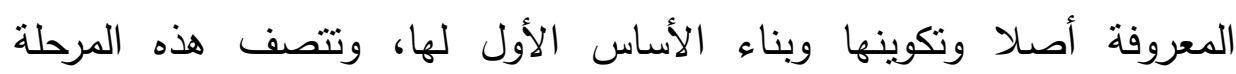

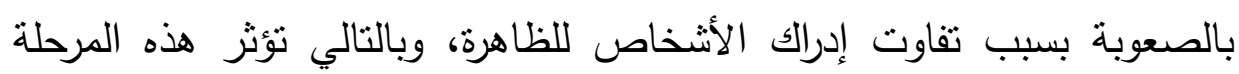
على طبيعة الصورة المتتكلة والمتأثزة بطبيعة الفرد ومستوى إدراكه.

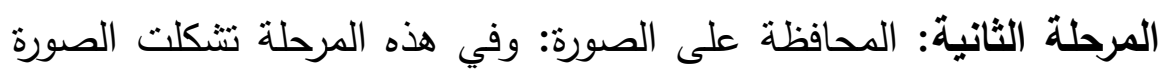

للى الأفراد عن الظاهرة، وأُخذت الانطباعات عنها ويكون لقنوات النوات التواصل وقناعات الفرد الدور الأكبر في الدحافظة على بقاء ثلك الصورة كما تشكلت في

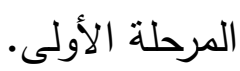

المرحلة الثالثة: استعادة الصورة: وتحدث هذه المرحلة عندما تتغير الصورة

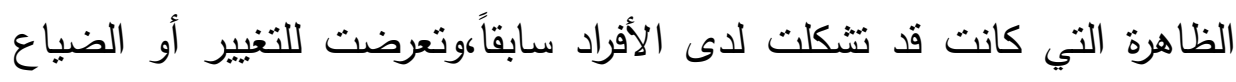

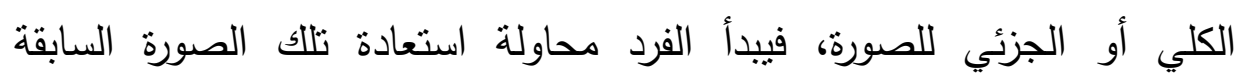
واسترجاعها.

وبناءً على ذلك فإن الصورة الذهنية تتثكل لاى الفرد عبر مراحل متعددة، ثم

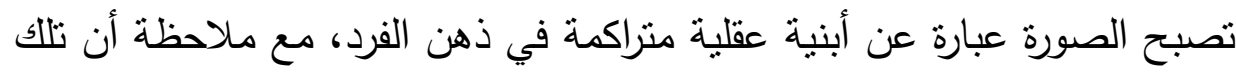

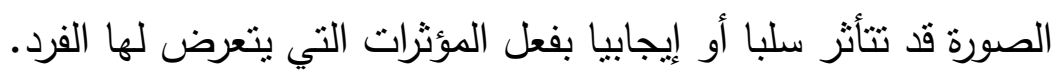
r. مكونات الصورة الذهنية:

تعد الصورة الذهنية بناءً متعدد الأبعاد؛ حيث تنتكل بواسطة انطباعات

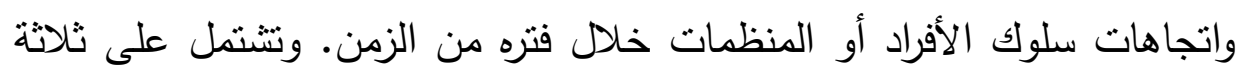
مكونات أو أبعاد أساسية تتمنل فيما يلي: الأراد المنظات • البعد أو المكون المعرفي (Cognitivecomponent): وهي المبلفي المعلومات

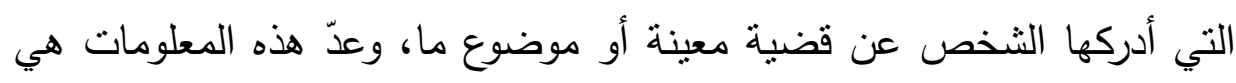




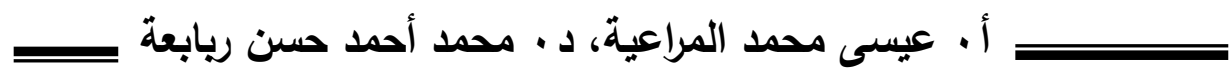

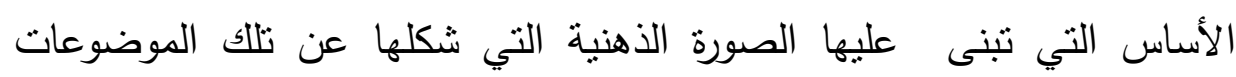

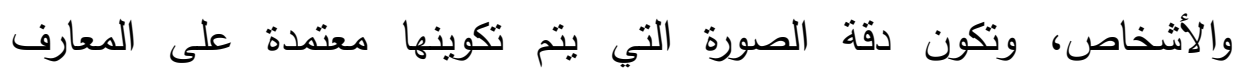
والمعلومات السابقة التي تنشكلت لدى الفرد عن الموضوعات والجهات. (الثيخ، $(\wedge: r \cdot 19$

• البعد أو المكون الوجداني (Affective component): يقصد بالبعد

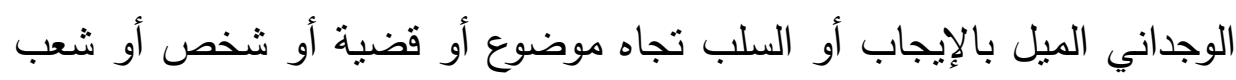

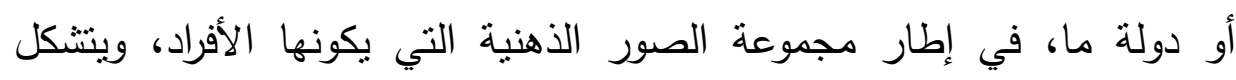

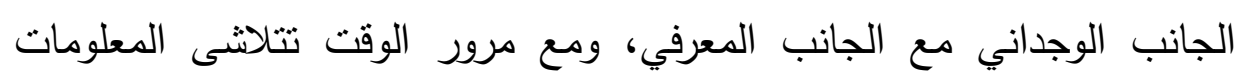

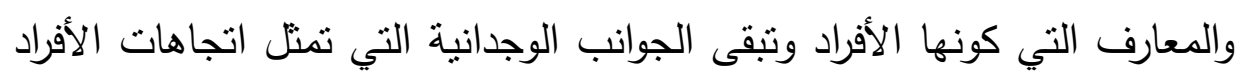

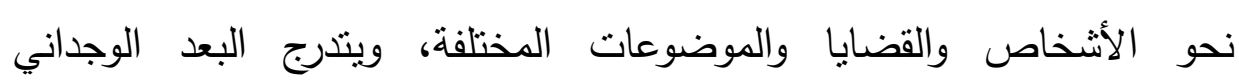

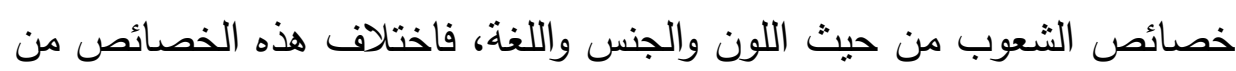

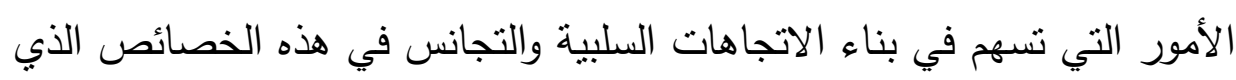

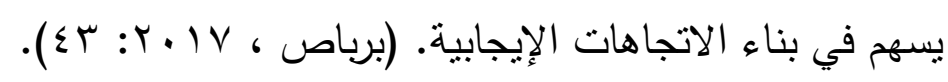

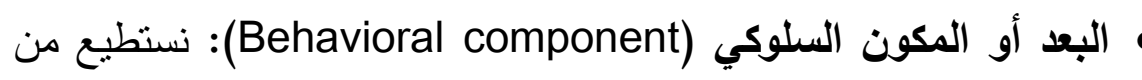

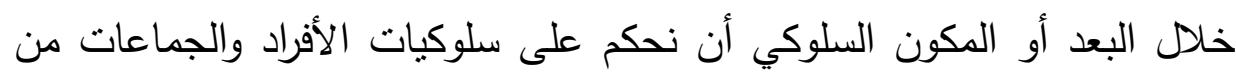

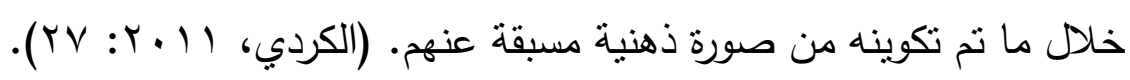

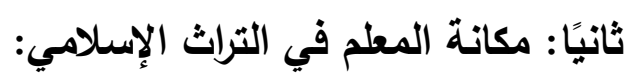
• من خلال استقراء جوانب من الصفحات المشرقة للتراث الإسلامي، نجد الإنداث

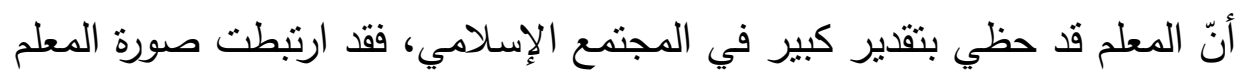

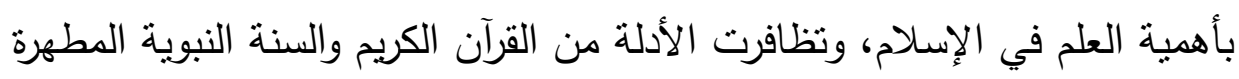

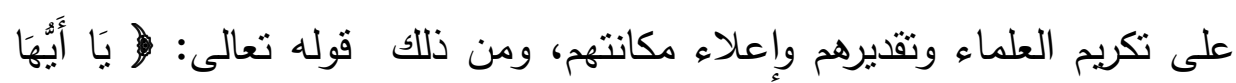

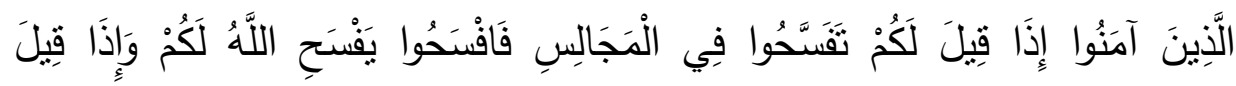

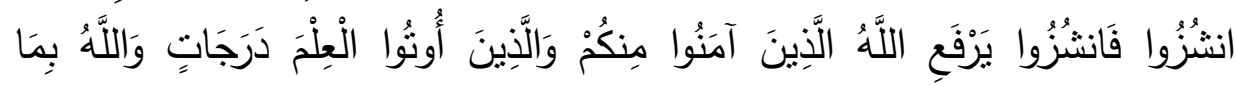

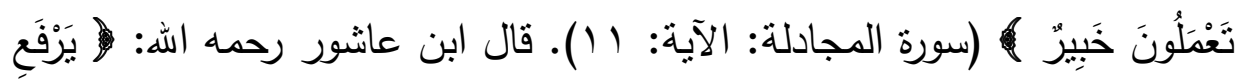




\section{الصورة الذهنية للمعلم}

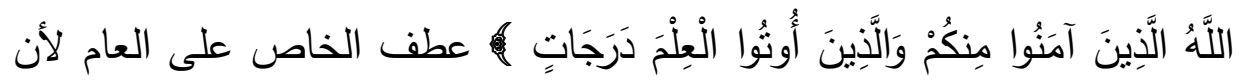
غشيان الرسول صلى الله عليه وسلم إنما هو لطلب العلم من مواعظه وتعليمه،

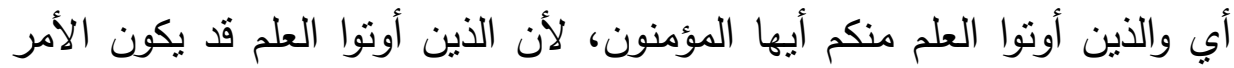

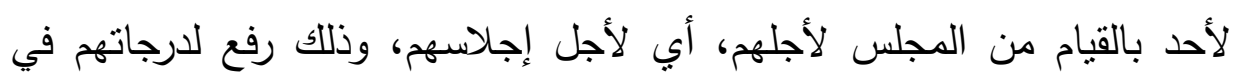

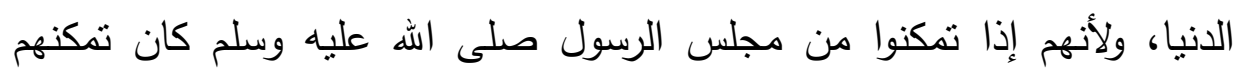

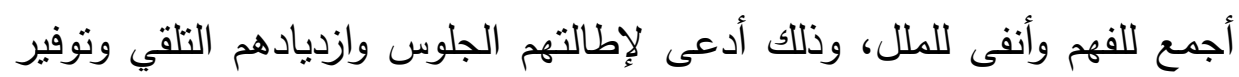
مستتبطات أفهامهم فيما يلقى إليهم من العلم، فإقامة الجالسين في الهجلس لألها لأجل

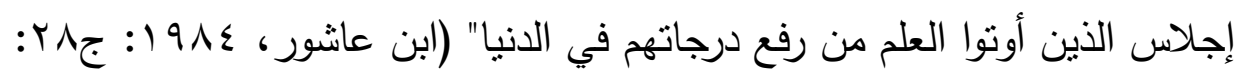

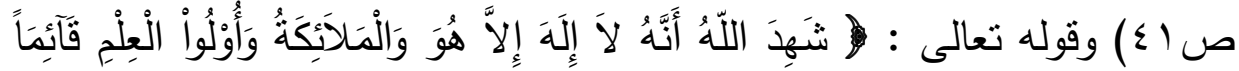

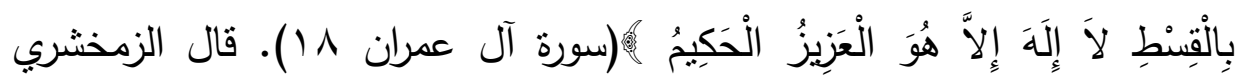
رحمه الله، " فإن قلت: ما المراد بأولى العلم الذين عظمهم هذا التعظيم حيث

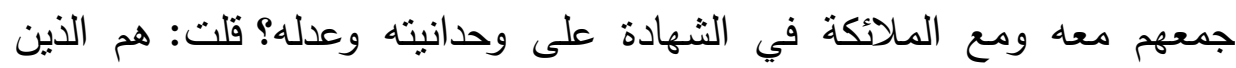

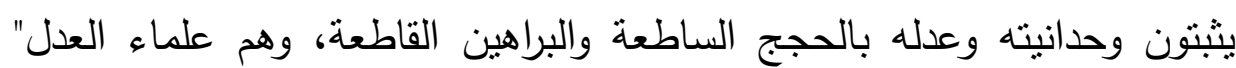

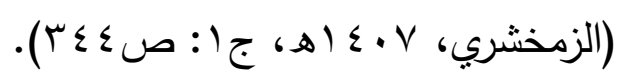

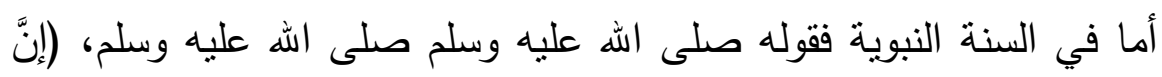

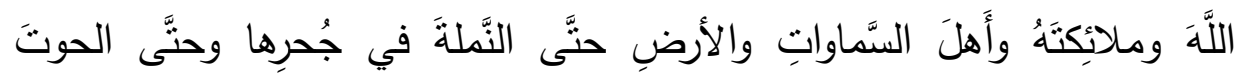

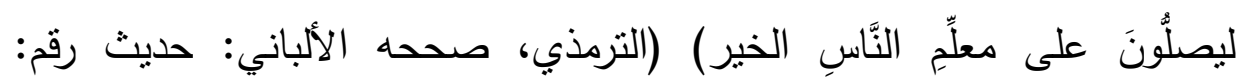

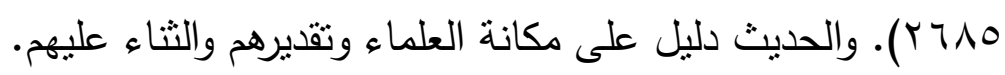
وظلت مكانة المعلم تحظي بتقدير المجتمع في عصور الدولة الإسلامية

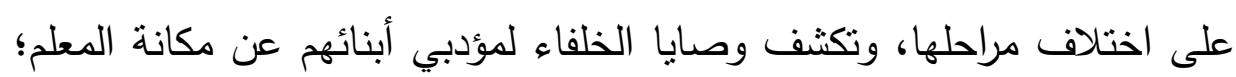

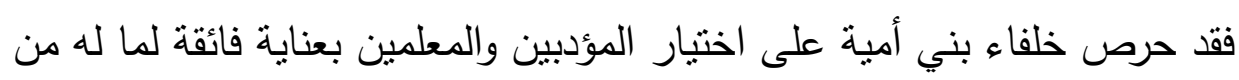

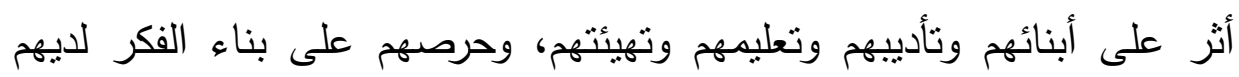

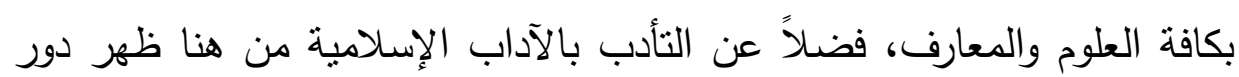




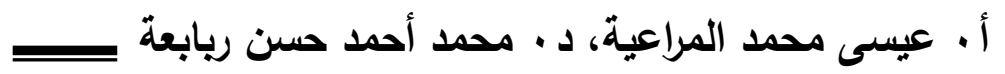

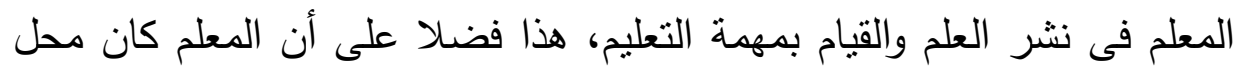

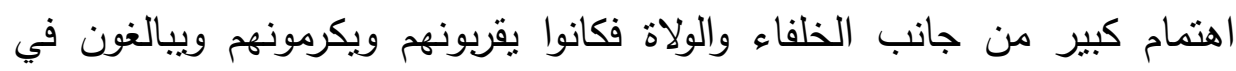

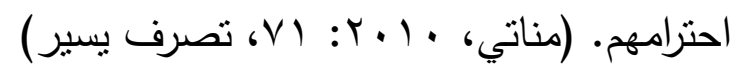

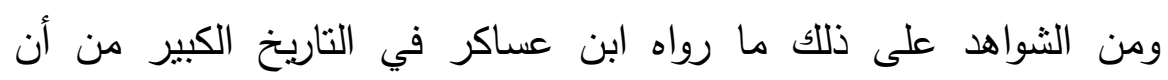

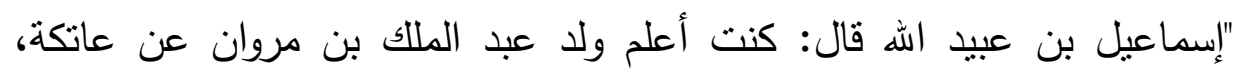

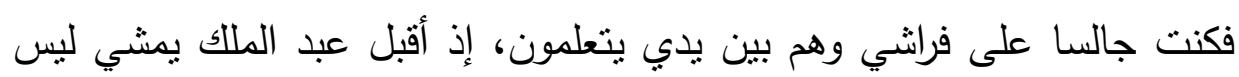

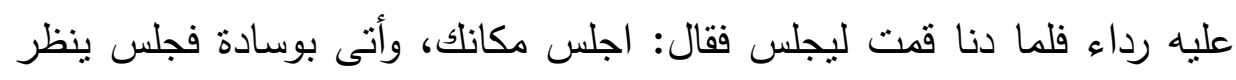

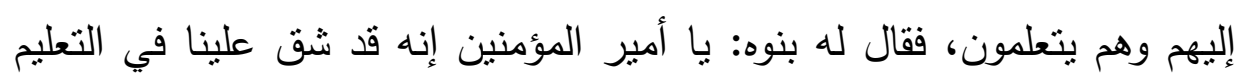

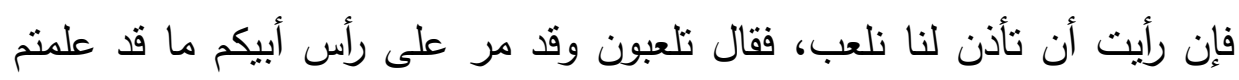

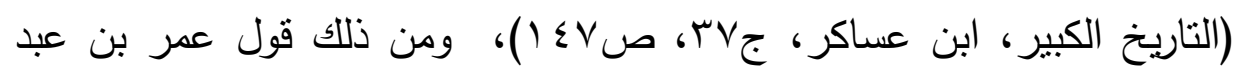

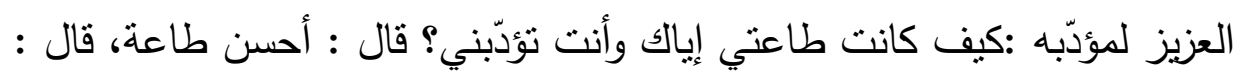
فأطعني الآن كما كنت أطيعك، خذ من شاربك حتى تبدو شفتاك، ومن ثُبك حتى إنى

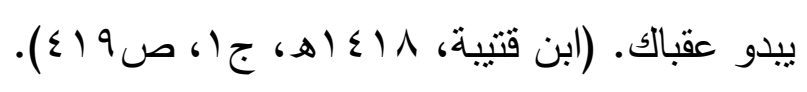

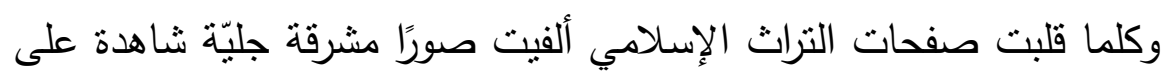

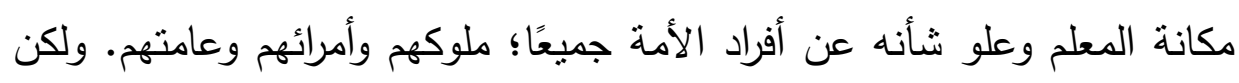

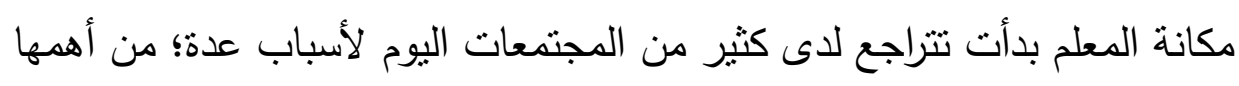

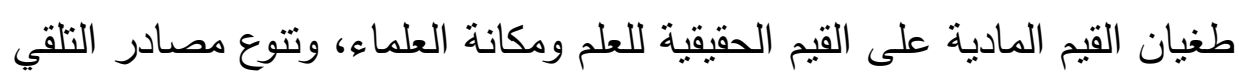

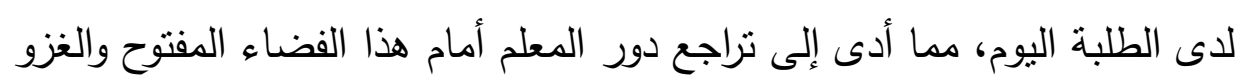
الفكري متتوع الثقافات والمصادر ، وغيرها. منهجية الاراسة وإجراءاتها: استخدم الباحثان المنهج الوصفي المسحي الميداني في هذه الدراسة، كونه

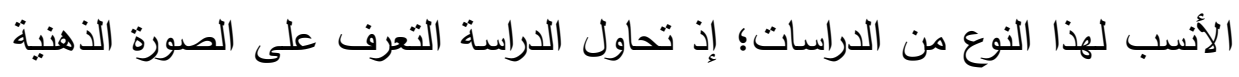

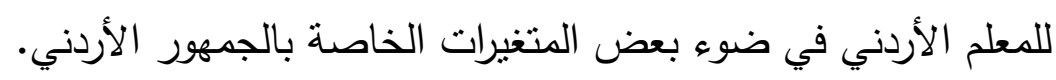




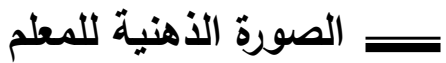

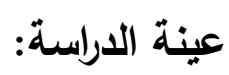

تم تطبيق هذه الدراسة على عينة من المجتمع الأردني من خلال توزيع

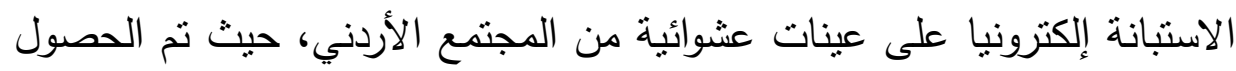

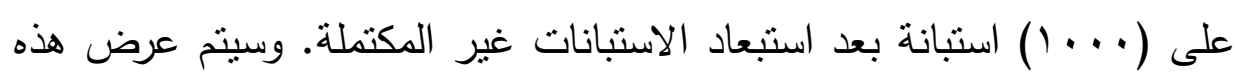
النتائج وفقاً لأسئلة الدراسة. وفيما يلي بيان للمعلومات الديمغرافية المتعلقة بأفراد العينة على النحو الآتي: لإنية

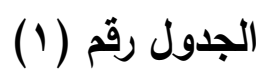

توزيع أفراد العينة بحسب المتغيرات الايمغرافية للاراسة

\begin{tabular}{|c|c|c|c|}
\hline النسبة \% & التكرار & الفئة & المتغير \\
\hline$\leq 9.9$ & $\sum 99$ & ذكر & \multirow{2}{*}{ النوع } \\
\hline $0 . .1$ & 0.1 & أنثى & \\
\hline 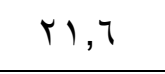 & $r 14$ & 11- •.r سنة & \multirow[t]{3}{*}{ العمر } \\
\hline$T, V$ & $T \cdot V$ & اس-.0 سنة & \\
\hline$I V, V$ & IVV & • • سنة فأكثر & \\
\hline $19, r$ & $19 \pi$ & أعزب/عزباء & \multirow{3}{*}{ الاجتماعي } \\
\hline rI & rl. & متزوج / م وليس لديه/ ها أبناء في & \\
\hline $09, v$ & ०qV & متزوج /لة ولديه / ها أبناء & \\
\hline$\varepsilon r, v$ & $\varepsilon r v$ & مدينة & \multirow{4}{*}{ مكان السكن } \\
\hline$\varepsilon \vee, \varepsilon$ & $\varepsilon V \varepsilon$ & قرية/ ريف & \\
\hline$v, v$ & VV & بادية & \\
\hline $1, r$ & ir & مخيم & \\
\hline $11, r$ & $11 \pi$ & ثانوية فأقل & المؤهل العلمي \\
\hline
\end{tabular}




\begin{tabular}{|c|c|c|}
\hline $0 \leqslant, \varepsilon$ & $0 \leq \varepsilon$ & دبلوم / بكالوريوس \\
\hline$r \varepsilon, r$ & $r \leqslant r$ & دراسات عليا \\
\hline
\end{tabular}

تشير هذه النسب التي شاركت وبصورة عشوائية إلى أن أفراد العينة الذين قاموا بالإجابة عن أسئلة الدراسة ينتمون لفئات مختلفة وبالتالي تكون عملية التعرف على طبيعة الصورة الذهنية للمعلم أكثر مصداقية لتعدد المتغيرات وتتوع الفئات.

أداة الدراسة: اعتمد الباحثان أداة الاستبانة لجمع المعلومات وصاغا مجالاتها، والفقرات التي تجيب عن كل مجال على حدة، وقد بلغ عدد فقراتها (10)، وقد توزعت على ستة مجالات وهى، طبيعة متابعة المبحوث للموضوعات الخاصة بالمعلم الأردني في وسائل الإعلام الأردنية، وله (سال) فقره، والصورة الذهنية العامة لدي عن المعلم الأردني، وله (ب0) فقرة، والصورة الذهنيّة الإيجاييّة التي تسهح وسائل الإعلام الأردنية في تشكيلها عن المعلم الأردني، وله (9) فقرات، والصورة الذهنيّة السلبيّة التي تسهم وسائل الإعلام الأردنية في تشكيلها عن المعلم الأردني، وله (ع () فقرة، والصورة الذهنيّة الإيجابيّة التي يُسهر المجتمع المحلي في تشكيلها عن المعلم الأردني، وله (ع () فقرة، والصورة الذهنيّة السلبية التي يُسهم المجتمع المحلي في تشكيلها عن المعلم الأردني، وله (·) فقرات.

\section{صدق الأداة (الاستبانـة):}

للنأكد من صدق الأداة فقد قام الباحثان بعرضها على عدد من المحكمين في مجال الدراسات الإسلامية والدراسات الإعلامية، وتم الاستفادة من ملاحظاتهم وإرشاداتهم بما يخدم الهدف الأساس لهذه الدراسة، من أجل تحقيق النتائج المرجوة 


\section{الصورة الأهنية للمعلم

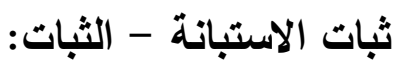

لضمان ثبات أداة الدراسة والتعرف على مدى انساق فقراتها في داخل كل

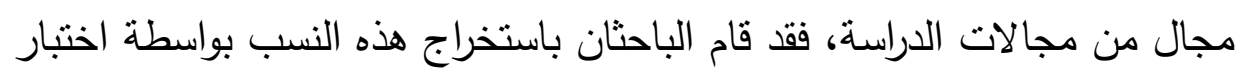
(كرومباخ ألفا)، والذي أعطى النسب الآتية:

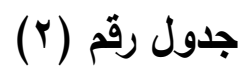

قيم مقياس ثبات الأداة (كرونباخ الفا) لمجالات الدراسة رجم

\begin{tabular}{|c|c|c|}
\hline 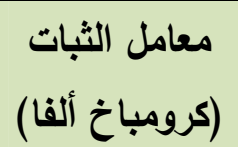 & 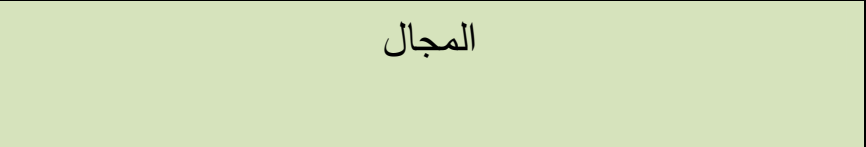 & 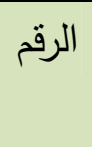 \\
\hline$\% q . .1$ & طبيعة متابعة المبحوث للألموضوعات الخاصة بالمعلم & .1 \\
\hline$\%$ \%..। & الصورة الذهنية العامة لدى عن المعلم الأردني &.$r$ \\
\hline$\% 90 . \mathrm{V}$ & في تشكيلها عن المعلم الأردني الإيجيّة التي تسهم وسائل الإعلام الأردنية & r \\
\hline$\% q \vee . r$ & في تشكيلها عن المعلم الأردني الذيّيّة السلبيّة التي تسهم وسائل الإعلام الأردنية &.$\varepsilon$ \\
\hline$\%$ \% . & تنكيلها عن المعلم الأردني الذهيّة الإيجايّة التي يُسهم المجتمع المحلي في & .0 \\
\hline$\% 97 . r$ & تتكيلها عن المعلم الأردني الذيّة السلبية التي يُسهم المجتمع المحلي في & .7 \\
\hline$\% 94.0$ & المجال الكلي & \\
\hline
\end{tabular}

من خلال النسب التي تم الحصول عليها في الجدول أعلاه والتي تراوحت ما

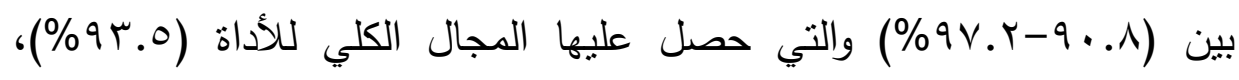

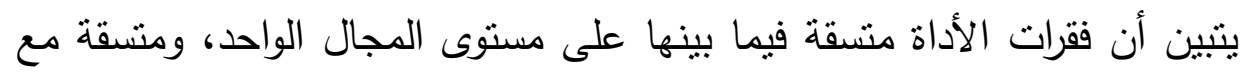
غيرها من فقرات المجالات الأخرى بصورة كبيرة جداً. 
أ . عيسى محمد المراعية، د . محمد أحمد حسن ريابعة

نتائج الاراسة الميدانية:

فيما يلي عرض لأبرز النتائج التي نم التوصل إليها :

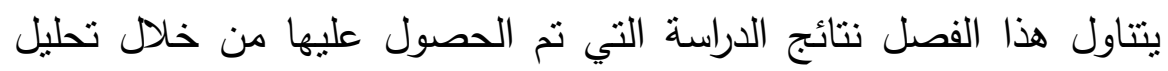

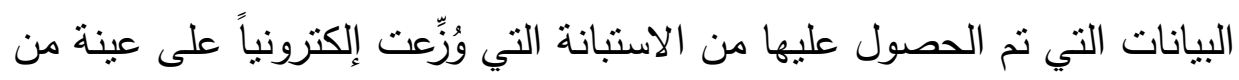

المجتمع الأردني، ثم مراجعتها وترتيبها وتفريغها باستخدام برنامج التحليل التحنيل

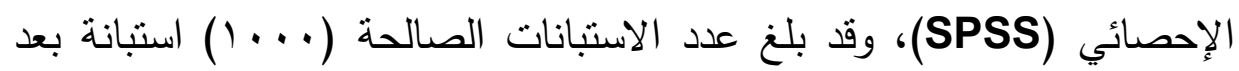

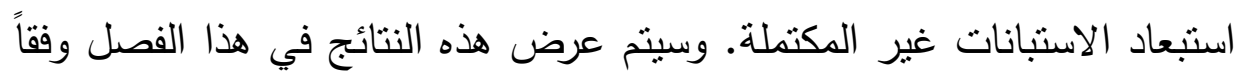
لأسئلة الدراسة.

وفيما يلي بيان للمعلومات الديمغرافية المتعلقة بأفراد العينة على النحو الآتي:

الجدول رقم (r)

توزيع أفراد العينة بحسب المتغيرات الايمغرافية للاراسة :

\begin{tabular}{|c|c|c|c|}
\hline النسبة \% & التكرار & الفئة & المتغير \\
\hline$\leq 9.9$ & $\sum 99$ & ذكر & \multirow[t]{2}{*}{ النوع } \\
\hline $0 . .1$ & 0.1 & أنثى & \\
\hline$r 1,7$ & rit & 11--ب سنة & \multirow{3}{*}{ العمر } \\
\hline $7 \cdot, \mathrm{V}$ & $7 . V$ & ا آ-0.0 سنة & \\
\hline$I V, V$ & IVV & •ـ سنة فأكثر & \\
\hline $19, r$ & 195 & أعزب/عزباء & \multirow{3}{*}{ الاجتماعي } \\
\hline rI & rl. & متزوج / الة وليس لديه/ هـا أبناء في & \\
\hline $09, v$ & $09 V$ & متزوج / الم ولديه / ها أبناء في & \\
\hline$\varepsilon r, v$ & $\varepsilon r v$ & مدينة & \multirow{4}{*}{ مكان السكن } \\
\hline$\varepsilon \vee, \varepsilon$ & $\varepsilon V \varepsilon$ & قرية/ ريف & \\
\hline$V, V$ & VV & بادية & \\
\hline $1, r$ & Ir & مخيم & \\
\hline
\end{tabular}




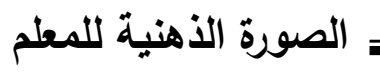

\begin{tabular}{|c|c|c|c|}
\hline $11, r$ & 111 & ثانوية فأقل & المؤهل العلمي \\
\hline $0 \leqslant, \varepsilon$ & $0 \leqslant \leq$ & دبلوم / بكالوريوس & \\
\hline$r \varepsilon, r$ & $r \leqslant r$ & دراسات عليا & \\
\hline
\end{tabular}

تشير هذه النسب التي شاركت وبصورة عشوائية بأن أفراد العينة الذين قاموا

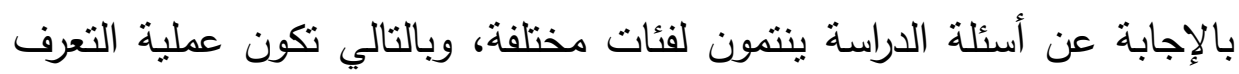
على طبيعة الصورة الذهنية للمعلم أكثر مصداقية لتعدد المتغيرات وتتوع الفئات.

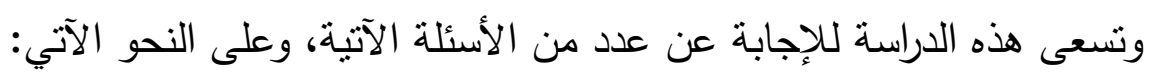
نتائج الإجابة عن السؤال الأول:

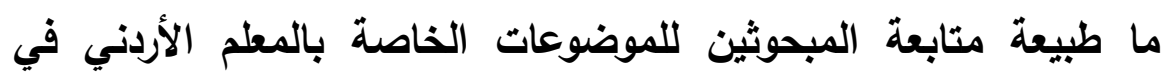

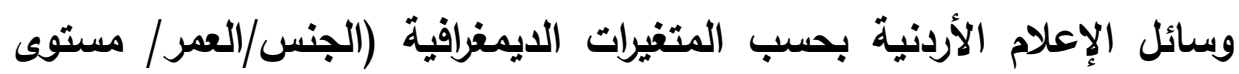
التعليم)؟ وللإجابة عن هذا السؤال فقد تم استخراج المتوسطات الحسابية والانحرافات

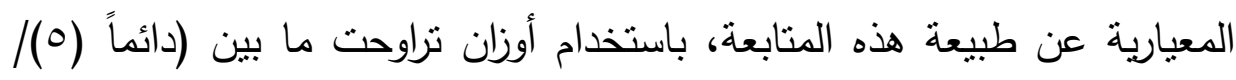

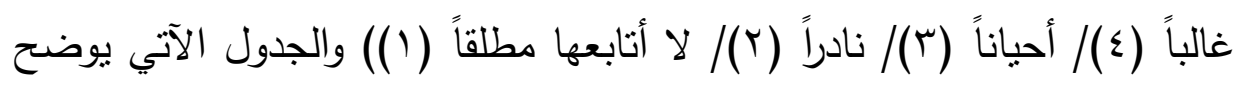
ذلك:

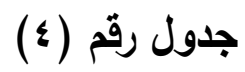

المتوسطات الحسابية والانحراقات المعيارية والنسب المئوية لمجال طبيعة روفة متابعة المبحوثين للموضوعات الخاصة بالمعلم الأردني في وسائل الإعلام الأردنية

\begin{tabular}{|c|c|c|c|c|}
\hline النسبة \% & المعياري - الانحراف & 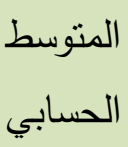 & الفقرة & الرقم \\
\hline$\Lambda \cdot . r$ & ד.914 & $\varepsilon_{.} .1$ & الأردني في البث المباشر لحراك الثارع & .1 \\
\hline$V \vee . \Lambda$ & 1 & $r . \wedge 9$ & الطلع على ما ينشر في الصحف &.$Y$ \\
\hline
\end{tabular}




\begin{tabular}{|c|c|c|c|c|}
\hline VI & 1.00 & r.А. & 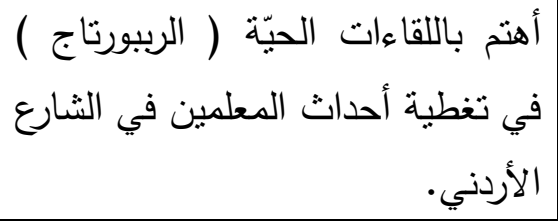 & r \\
\hline Vo. 7 & $1 . . r$ & r.v^ & 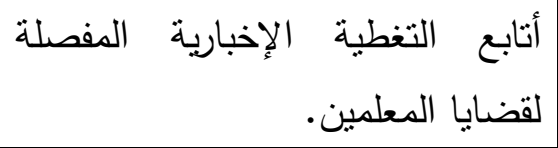 & . $\varepsilon$ \\
\hline Vr.A & 1.17 & r.79 & أحرص على تتويع مصادر معلوماتي & .0 \\
\hline r & $1 . . v$ & r.70 & 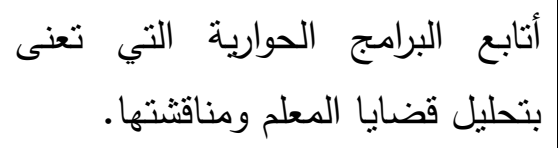 & .7 \\
\hline$v \cdot . \wedge$ & 1.1 & r.oz & أنابع التقارير التي تبثها وسائل &.$V$ \\
\hline$V \cdot .7$ & 1.1 & $r .0 r$ & 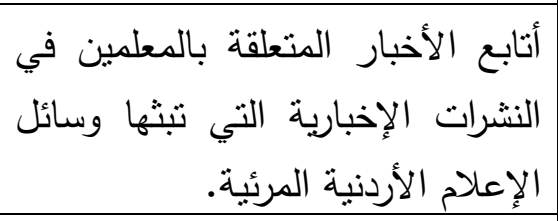 & .1 \\
\hline$v$. & 1.11 & r.o. & 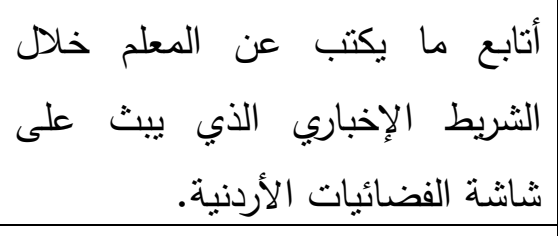 & .9 \\
\hline 71.7 & 1.1 & سء. r & 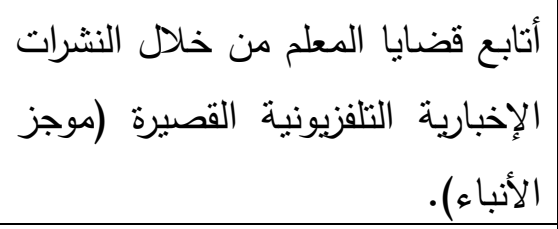 & .1 . \\
\hline $7 \varepsilon$ & $1 . r$ & r.r & 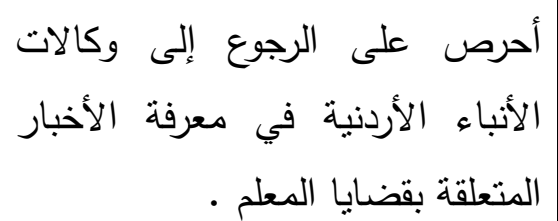 & .11 \\
\hline
\end{tabular}




\begin{tabular}{|c|c|c|c|c|}
\hline $7 \cdot . \varepsilon$ & 1.11 & $r . \cdot r$ & أتابع الأخبار المتعلقة بالمعلمين في & $.1 r$ \\
\hline $09 . \varepsilon$ & r. & r.9V & 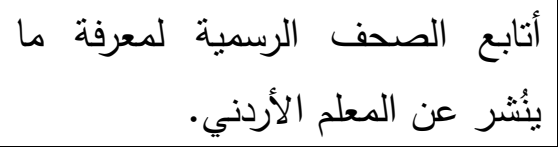 & r \\
\hline$v \cdot . \wedge$ & r & r.os & المجال الكلي & \\
\hline
\end{tabular}

حصلت الفقرات التي يتكون منها مجال طبيعة منابل منابعة المبحوثين

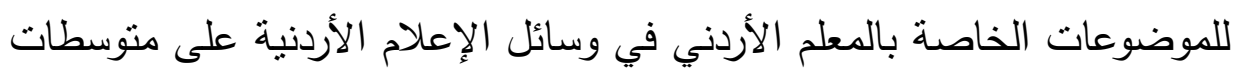

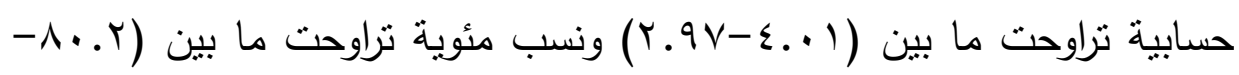

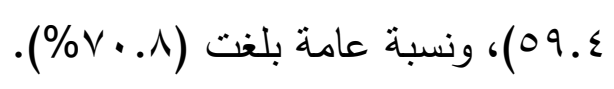

وقد تبين أن الفقرات الخمس الأولى التي حصلت على ألى أعلى متوسطات

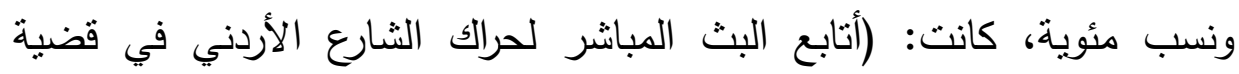

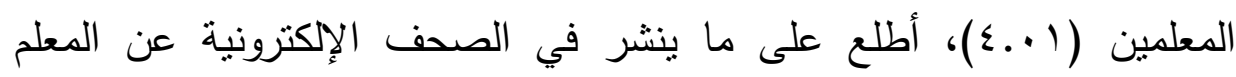

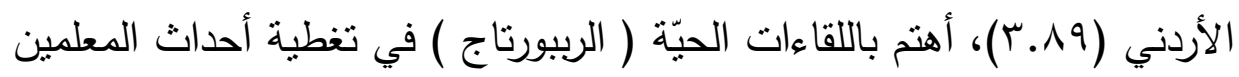

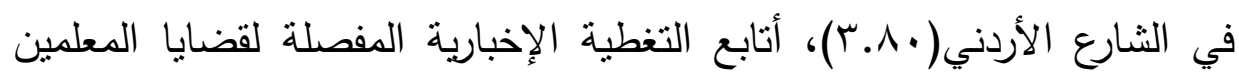

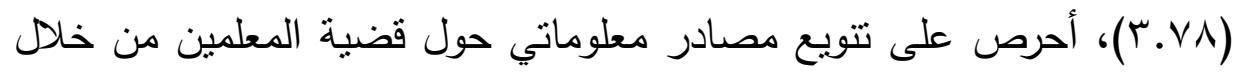

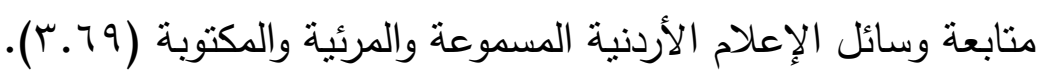
وللتعرف على وجود فروق معنوية بين المتغيرات، فقد نم إجراء تحليل التباين الأحادي، وعلى النحو الآتي: 


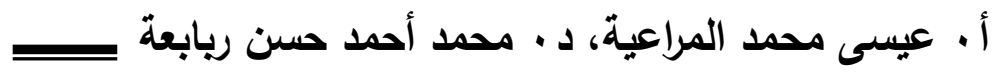

جدول رقم (0)

نتائج تحليل التباين لأثر متغيرات (النوع/العمر/ الحالة الاجتماعية/ مكان

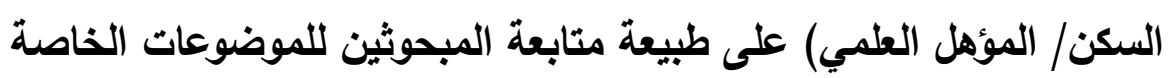

بالمعلم الأردني في وسائل الإعلام الأردنية

\begin{tabular}{|c|c|c|c|c|c|}
\hline الدلالة & قيمة ف & درجات & المربعات & المربعات & المتغير \\
\hline$. r \leq q$ & $\therefore \wedge \vee q$ & 1 &. $.01 Y$ &. $.01 Y$ & النوع \\
\hline$\ldots v$ & $\varepsilon .94$ & r & 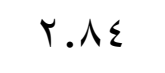 & 0.79 & العمر \\
\hline . & I.rT & r &.$V V Y$ & $1.0 \leqslant$ & الاجتماعي \\
\hline .rVq & $1 . . r$ & r &. .099 & 1.199 & مكان \\
\hline דצדי. & $1 \ldots v$ & r &. .017 & $1.1 \mathrm{~V}$ & العؤهي \\
\hline
\end{tabular}

يلاحظ من الجدول السابق أن هناك فروقًا ذات دلالة إحصائية على طبيعة متابعة المبحوثين للموضوعات الخاصة بالمعلم الأردني في وسائل الإعلام الأردنية تعزى لمتغير العمر. وباستخدام مقياس (شيفيه) للمقارنات البعدية تبين

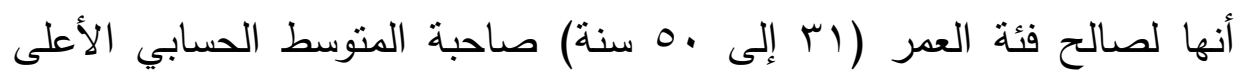

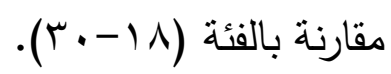

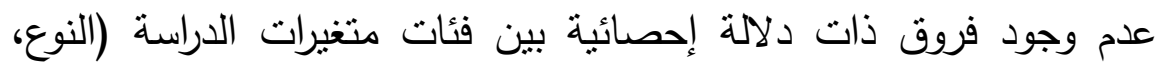
الوضع الاجتماعي، مكان السكن، المستوى العلدي). 
ت

نتائج الإجابة عن السؤال الثاني:

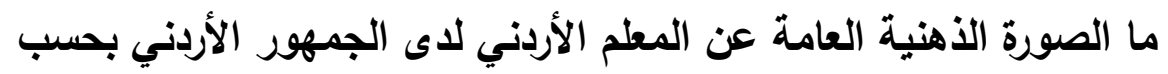

\section{المتغيرات الايمغرافية}

(الجنس/العمر/ مستوى التعليم)؛

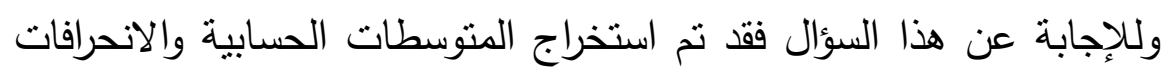

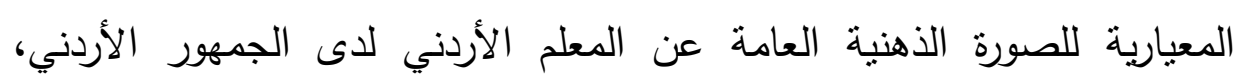

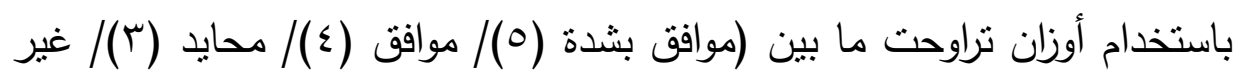

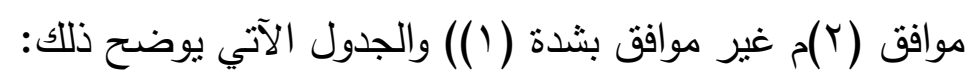

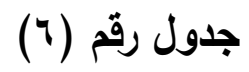

المتوسطات الحسابية والانحرافات المعيارية والنسب المئوية لمجال للصورة

\begin{tabular}{|c|c|c|c|c|}
\hline النسبة \% & 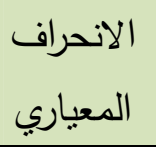 & المتوسط & مجالات الدراسة & 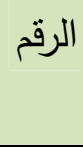 \\
\hline 94 & $. .7 \times 1$ & «.7. & يحب وطنه وينتمي له. & 1 \\
\hline 91.4 &. .710 & $\{.07$ & | يغار على أمته ودينه. & r \\
\hline$\wedge 9.7$ & $\therefore v 00$ & $\varepsilon . \S \wedge$ & الوطنية. على الدفاع عن القضايا & $r$ \\
\hline ᄉ9.乏 &.$V V R$ & $\varepsilon . \varepsilon \vee$ & يسهم في خدمة المجتمع المحلي. & $\varepsilon$ \\
\hline ᄉт.А & .vor & $\varepsilon . \Gamma \varepsilon$ & | يشارك المجتمع المحلي في المناسبات & 0 \\
\hline ᄉт.ร &. $.1 \cdot 7$ & E.TY & ينتمي لمهنته التربوية والتعليمية. & 7 \\
\hline NT.r & $\because \vee \vee \wedge$ & 纟.M & يمنالك خبرات حياتية وواقعية. & v \\
\hline $10 . \varepsilon$ &.. ATV & E.TV & يمتلك شخصية مؤثرة في مجتمعه . & $\wedge$ \\
\hline 10.r & $\cdot . \wedge \cdot \varepsilon$ & 纟.Y૫ & والمؤسسيّة. & 9 \\
\hline
\end{tabular}

$-\vee \vee \neg-$ 
أ • عيسى محمد المراعية، دـ ـ محمد أحمد حسن ريابعة

\begin{tabular}{|c|c|c|c|c|}
\hline 10 &. .10 & E.ro & يُسهم في التغيير الإيجابي في المجتمع & 1. \\
\hline$\wedge \varepsilon . \wedge$ &..$\wedge 1 \mathrm{~V}$ & $\varepsilon . r \varepsilon$ & | يمتل قدوة في الأخلاق والقيم. & 11 \\
\hline$\Lambda \varepsilon . r$ &. .117 & $\{. r)$ & |التعليمية. & ir \\
\hline$\wedge \varepsilon$ &..$\wedge \varepsilon \varepsilon$ & s.r. & | يمتلك شخصية مؤثرة في الآخرين. & 14 \\
\hline Ar.A & $. . \wedge \leq \varepsilon$ & $\{.19$ & والتعليمي. & $1 \leqslant$ \\
\hline ᄉঙ.ч &. .170 & ๕.11 & | يحافظ على وقت دوامه وعمله. & 10 \\
\hline ᄉr.t & $. \wedge \leqslant 7$ & $\varepsilon .11$ & |يؤدي رسالته التربوية والتعليمية بأمانة. & 17 \\
\hline$\Lambda$ Ar. &. .14 & 纟. $1 \leqslant$ & | يحافظ على مظهره وأناقته. & iv \\
\hline Ar.A & $. . \wedge T \leqslant$ & 纟.) & | يشجع طلبته على التميز والإبداع. & in \\
\hline Ar.T &..$\wedge 71$ & E.1T & يؤدي رسالته بكفاءة واقتنار . & 19 \\
\hline AT.Y & 证. & «.11 & | لمشكلات الصنات الصفية المختلفة. التعامل مع & r. \\
\hline$\wedge 1 . \wedge$ &. .110 & $\varepsilon . .9$ & ليمتلك وعيًا وفهمًا سياسيًاً. & r) \\
\hline$\wedge 1 . \wedge$ &. .109 & $\varepsilon . .9$ & و والتعليمية. الكفايات المعرفية والتزبوية & r \\
\hline 11.1 & $\cdot . \wedge \leq q$ & $\{. .9$ & طلبته. بحرص على مراعاة الفروق الفردية بين & r \\
\hline V.. & $. .9 v /$ & r.AT & 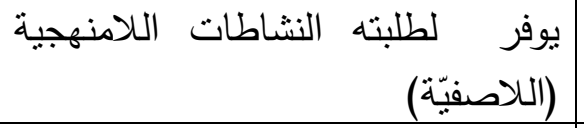 & $r \varepsilon$ \\
\hline or.1 & $1 . \mathrm{rV}$ & $r .79$ & | يحصل على دخل يُناسب احتباجاته & ro \\
\hline AT.T &. .704 & Ł.11 & المجال الكلي & \\
\hline
\end{tabular}

$$
\text { تبين من الجدول السابق الآتي: }
$$

تراوحت الفقرات التي تمت الإجابة عنها في هذا المجال في منوسطاتها

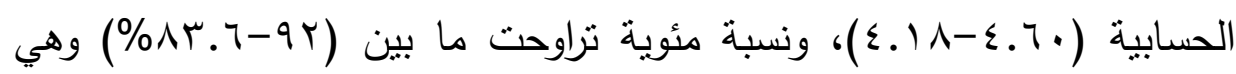




\section{الصورة الذهنية للمعلم}

نسب مرتفعة جداً؛ حيث جاء المتوسط العام (^.؟) والنسبة المئوية الكلية .$(\% \wedge r .7)$

وقد حصلت أعلى خمس فقرات على متوسطات عالية، وكانت هذه الفقرات

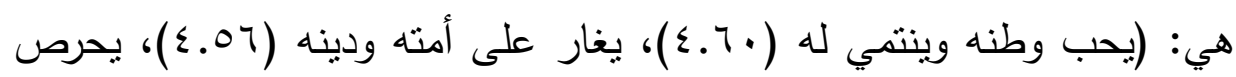

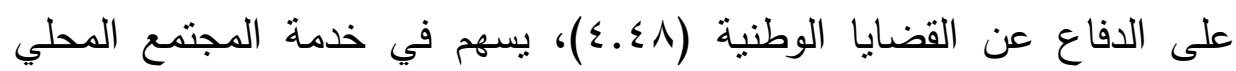

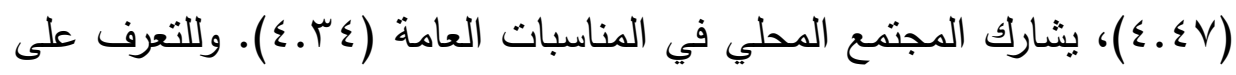

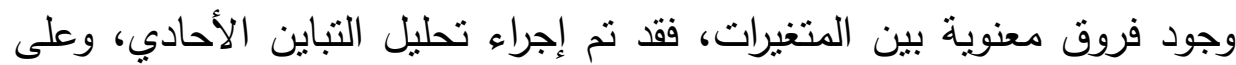

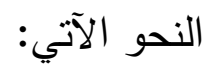

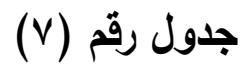

نتائج تحليل التباين لأثر متغيرات (النوع/العمر/ الحالة الاجتماعية/ مكان

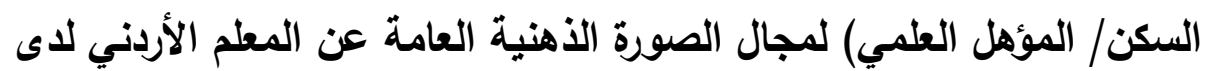

\begin{tabular}{|c|c|c|c|c|c|}
\hline الدستوى & قيمة ف & الحرية & المربعات & المربعات & المتغير \\
\hline$\cdots 71$ & س. & 1 & $1 . \varepsilon \varepsilon$ & $1 . \varepsilon \varepsilon$ & النوع \\
\hline س . . . . & $r . \leqslant r$ & r & $1 . \leqslant V$ & 4.90 & العمر \\
\hline$\ldots 97$ & T.r & r & $1 . .1$ & r... & الاجتماعي \\
\hline$* \ldots .1$ & 0.11 & $r$ & Y.YI & 7.70 & مكان السكن \\
\hline$* \ldots r r$ & r.vq & $r$ & 1.74 & r.ru & المؤهل العلمي \\
\hline
\end{tabular}

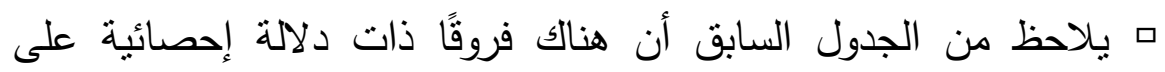

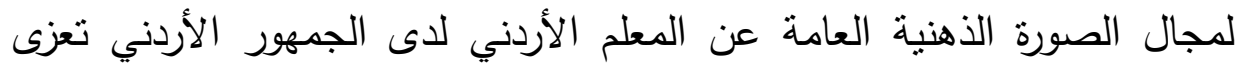

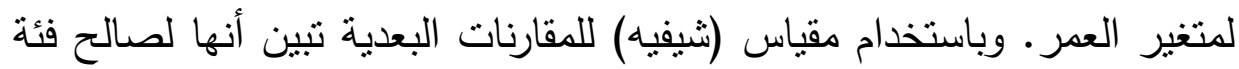




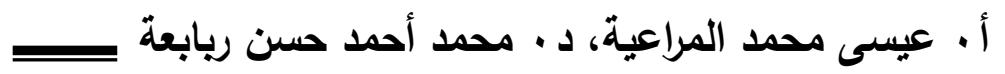

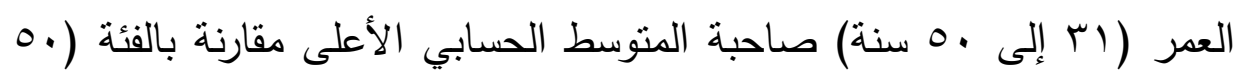
سنة فأكثر ).

ه وتبين كذلك وجود فروق ذات دلالة إحصائية على لمجال الصورة الذهنية العامة عن المعلم الأردني لدى الجمهور الأردني تعزى لمتغير مكان السكن. وباستخدام مقياس (شيفيه) للمقارنات البعدية تبين أنها لصالح فئة السكن (قرية/ريف) صاحبة المتوسط الحسابي الأعلى مقارنة بالفئة (مدينة). ه وتبين كذلك وجود فروق ذات دلالة إحصائية على لمجال الصورة الذهنية العامة عن المعلم الأردني لاى الجمهور الأردني تعزى لمتغير المستوى العلمي. وباستخدام مقياس (ثنيفه) للمقارنات البعدية تبين أنها لصالح فئة (دبلوم/ بكالوريوس) صاحبة المتوسط الحسابي الأعلى مقارنة بالفئة (دراسات نتائج الإجابة عن السؤال الثالث: ما دور وسائل الإعلام في تثكيل الصورة الذهنية للمعلم الأردني بحسب المتغيرات الايمغرافية (الجنس/العمر/ مستوى التعليم)؟ وللإجابة عن هذا السؤال فقد تم تقسيم الإجابة عن هذا السؤال إلى قسمين، القسم الأول متعلق بالصورة الذهنية الإيجابية، والثاني متعلق بالصورة الذهنية السلبية، وعلى النحو الآتي: أولاً: دور وسائل الإعلام في تثكيل الصورة الاهنية الإيجابية للمعلم الأردني: تم استخراج المتوسطات الحسابية والانحرافات المعيارية للإجابات التي أعطيت باستخدام أوزان تراوحت ما بين (دائماً (0)/ غالباً (ع)/ أحياناً (r)/ نادراً (Y)/ لا أتابعها مطلقاً ( ()) والجدول الآتي يوضح ذلك: لراسن 


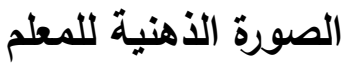

جدول رقم (^)

المتوسطات الحسابية والانحرافات المعيارية والنسب المئوية لمجال دور وسائل الإعلام في تثكيل الصورة الذهنية الإيجابية للمعلم الأردني

\begin{tabular}{|c|c|c|c|c|}
\hline النسبة \% & الالمعراف & الحسابي & مجالات الدراسة & 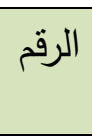 \\
\hline$T \leqslant .7$ & $1.1 \varepsilon$ & T.rT & تقام صورة إيجابية للمعلم الأردني & .1 \\
\hline 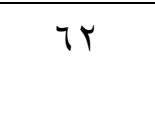 & I.r. & r.l. & تُظهر المعلم الأردني بصورة إيجابية & . \\
\hline 01 & 1.17 & r.9. & تعملاته بتشاركية مع المعلم لإيجاد حلول & r \\
\hline ov.乏 & 1.19 & r.AV & تضاياه إعلاميًا لظهور المعلم ودفاعه عن &.$\varepsilon$ \\
\hline OV.r & 1.17 & r.AT & قضايا المعلم مساحة إعلامية كافية لمناقشة & .0 \\
\hline 07.1 & I.rY & T.A & تتنبنى قضايا المعلم الأردني وتدافع عنها & .7 \\
\hline 07 & $1.1 \pi$ & Y.A. & تتظم لقاءات حوارية متكافئة بين المعلم &. $\mathrm{V}$ \\
\hline or & $1 . \mathrm{YA}$ & $r .70$ & تحيُّز 2 تضايا المعلمين بشفافية ودون &.$\wedge$ \\
\hline or.s & $1.1 \mathrm{~V}$ & r.Tr & لجرض موقف الثنارع من ميدانية محايدة & .9 \\
\hline ov.乏 & $1 . . r$ & Y.AV & المجال الكلى & \\
\hline
\end{tabular}
تنين من الجدول السابق الآتي:

تراوحت الفقرات التي تمت الإجابة عنها في هذا المجال في منوسطاتها

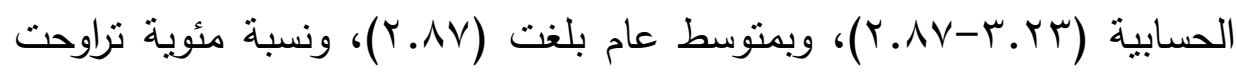

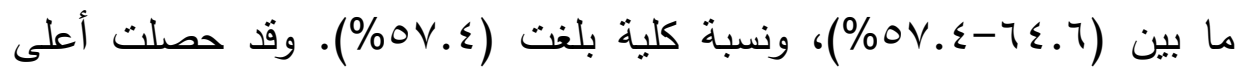
خمس فقرات على منوسطات عالية، وكانت هذه الفقرات هي: تقدم صورة إيجابية 


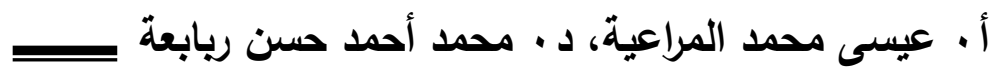

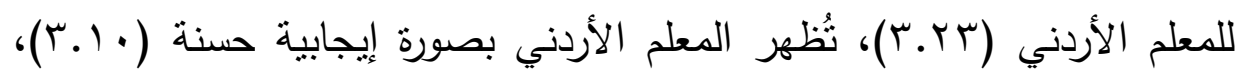

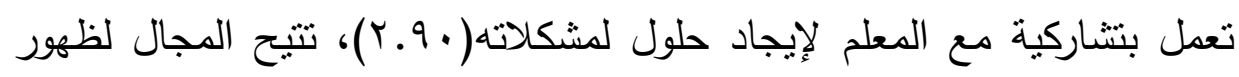
المعلم ودفاعه عن قضاياه إعلاميًًا (Y.Av)، تعطي مساحة إعلامية كافية لمناقثنة قضايا المعلم (Y.人. (Y). وللتعرف على وجود فروق معنوية بين المتغيرات، فقد نم إجراء تحليل التباين

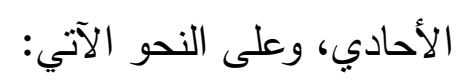

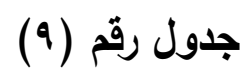

نتائج تحليل التباين لأثر متغيرات (النوع/العمر / الحالة الاجتماعية/ مكان

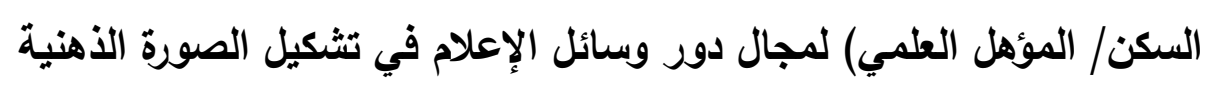
الإيجابية للمعلم الأردني

\begin{tabular}{|c|c|c|c|c|c|}
\hline الدلالة & قيمة ف & الحرية & متوسط المربعات & المربعات & المتغير \\
\hline$. r \leq 7$ & $1 . r \varepsilon$ & 1 & $1 . \leqslant 1$ & $1 . \varepsilon 1$ & النوع \\
\hline$\ldots \ldots$ & rr... & r & $\mathrm{r} 1.7$ & Tr. & العمر \\
\hline$\ldots \ldots$ & $1 \% .7$. & $r$ & $1 \% .9$. & TV.A. & الاجتماعيع \\
\hline$\ldots \ldots$ & 17.11 & $r$ & Tr, & rq.v^ & مكان السكن \\
\hline$\ldots \ldots$ & IV.rT & r & $1 V .01$ & $r 0.17$ & لمؤهل العلمي \\
\hline
\end{tabular}
يلاحظ من الجدول السابق أن هناك فروقًا ذات دلالة إحصائية لمجال دور

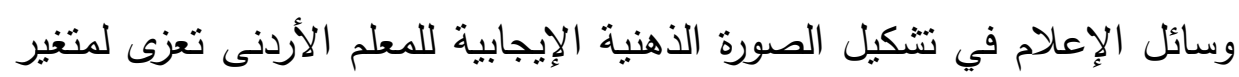

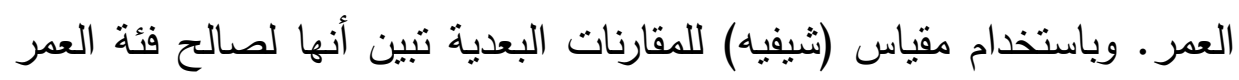
(1) إلى . r سنة) صاحبة المتوسط الحسابي الأعلى مقارنة بالفئتين الأخريين

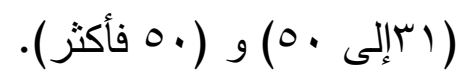




\section{=}

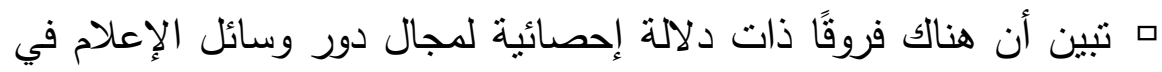
تتككيل الصورة الذهنية الإيجابية للمعلم الأردنى تعزى لـتغير الحالة دالة الاجتماعية.

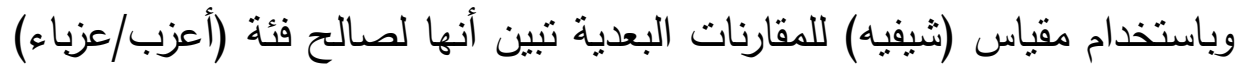
صاحبة المتوسط الحسابي الأعلى مقارنة بالفئتين الأخريين.

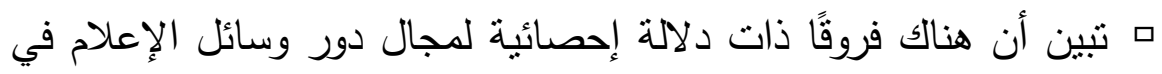

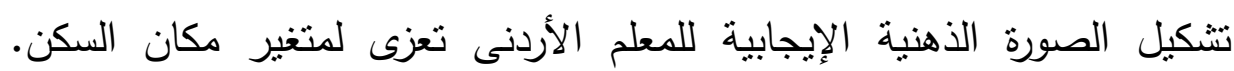

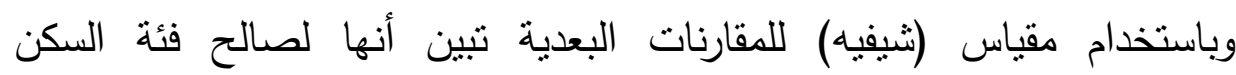

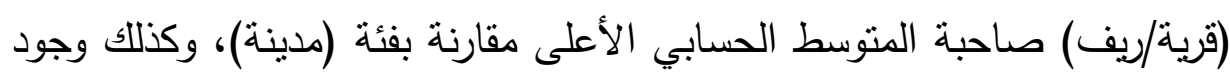
فروق ذات دلالة إحصائية لصالح فئة (بادية) في مقابل فئة (مدينة).

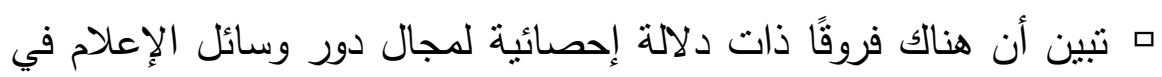

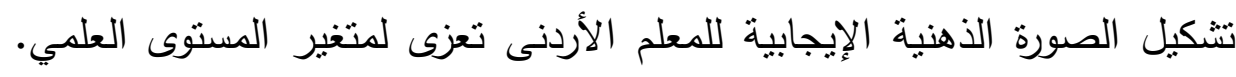

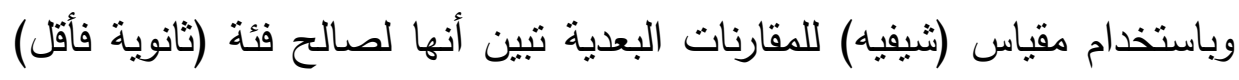
صاحبة المتوسط الحسابي الأعلى مقارنة بالفئتين الأخريين. ثانياً: دور وسائل الإعلام في تثكيل الصورة الذهنية السلبية للمعلم الأردني:

تم استخراج المتوسطات الحسابية والانحرافات المعيارية للإجابات التي

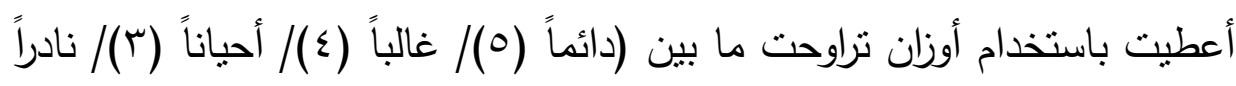

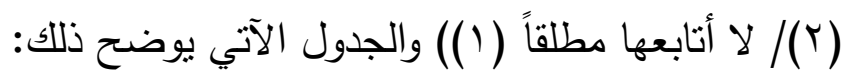




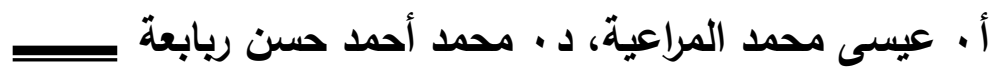

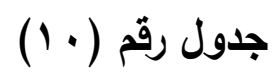

المتوسطات الحسابية والاتحرافات المعيارية وإلنسب المئوية لمجال دور وسائل الإعلام في تثكيل الصورة الذهنية السلبية للمعلم الأردني

\begin{tabular}{|c|c|c|c|c|}
\hline ا النسبة \% & 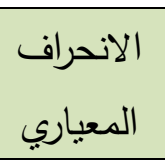 & الحسابي & مجالات الدراسة ل & 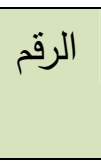 \\
\hline$V \varepsilon . Y$ & 1.10 & r.VI & تحمّل المعلم مسؤولية الأزمة التعليمية في & .1 \\
\hline VT.A & $9 . \wedge 1$ & $r .79$ & تالإيجابية للمعلم. مضامينها الإعلامية الجوانب &.$Y$ \\
\hline$\vee 1.1$ & $1 . r \varepsilon$ & $r .09$ & الثخهر المعلم بصورة الباحث عن المصلحة &.$r$ \\
\hline$v 1 . \varepsilon$ & $1 . .1$ & $r .0 \mathrm{~V}$ & تتحيّز في طرحها ضد قضايا المعلمين. &.$\varepsilon$ \\
\hline VI. & 1.11 & r.ov & تسوغ وتبرر آراء المخالفين لقضايا & .0 \\
\hline$V \cdot . \varepsilon$ & $1.1 \%$ & r.or & تستضيف نُخبًا وشرائح مجتمعية تنتقد & .7 \\
\hline v. & 1.51 & r.o. & تبرز المعلم بصورة المستغل للطلبة لغايات &.$V$ \\
\hline 79.1 & 1.19 & r. $\varepsilon q$ & تسهم في إيجاد فجوة بين المعلم والمجتمع & . \\
\hline $79 . \varepsilon$ & 1.19 & $r . \Sigma V$ & تسعى لكسب تأييد المجتمع ضد قضايا & .9 \\
\hline $7 \wedge .1$ & 1.19 & r. & تصور المعلم بصورة المخالف للأنظمة & 1. \\
\hline$T V$ & $1 . r v$ & r.ro & 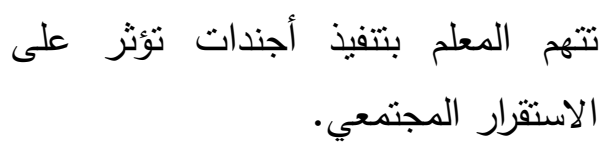 & .11 \\
\hline
\end{tabular}




\begin{tabular}{|c|c|c|c|c|}
\hline 70.1 & I.rV & T.Y & المعلمين. & r \\
\hline זד & or & r.10 & 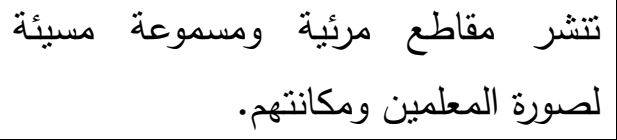 & سו. \\
\hline 09.1 & 1.19 & $r .99$ & وانتقاصث عن المعلم بأسلوب فيه سخرية & $.1 \leq$ \\
\hline 79 & $1 . .1$ & r. $\leqslant 0$ & \multicolumn{2}{|l|}{ المجال الكلي } \\
\hline
\end{tabular}

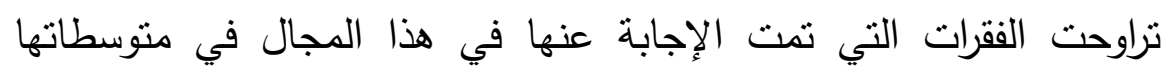

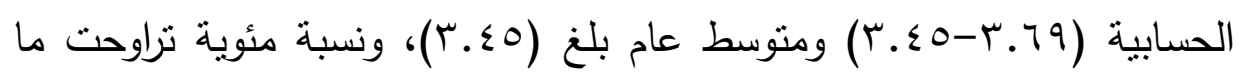

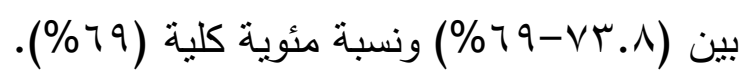

وكانت الفقرات الخمس الأولى من حيث المتوسط الحسابي هي: (تحمّل (لتهل

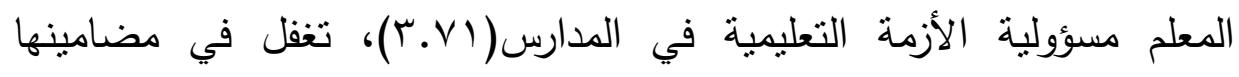

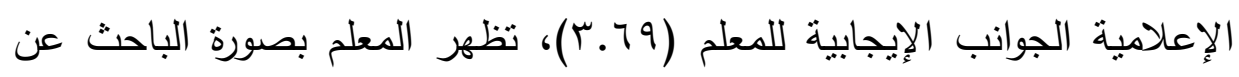

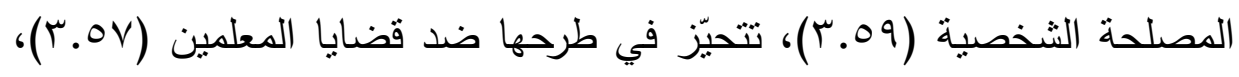
تسوغ وتبرر آراء المخالفين لقضايا المعلمين (r.ov). وللتعرف على وجود فروق معنوية بين المتغيرات، فقد تم إجراء تحليل التباين الأحادي، وعلى النحو الآتي: 


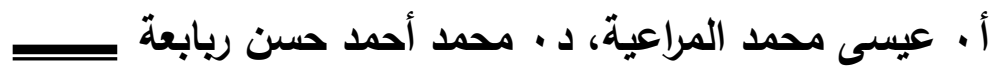

$$
\text { جدول رقم (11) }
$$

نتائج تحليل التباين لأثر متغيرات (النوع/العمر / الحالة الاجتماعية/ مكان

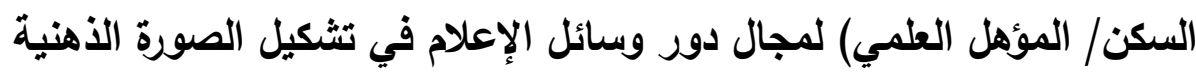
السلبية للمعلم الأردني الاعلي

\begin{tabular}{|c|c|c|c|c|c|}
\hline الدلالة & قيمة ف & درجات & المربعات متوسط & المربعات & المتغير \\
\hline$\ldots \cdots 1$ & 11.10 & 1 & 1 1T.7. & 1 1T.7. & النوع \\
\hline$\ldots \ldots$ & TV.Ar & r & $\varepsilon \cdot . \wedge \wedge$ & 1).Vo & العدر \\
\hline$\ldots$ & 9.17 & r & $11 . r \leq$ & YY.EA & الاجتماعي \\
\hline$\ldots \ldots$ & $1 \cdot . r$. & r & $11.7 r$ & $\Gamma \varepsilon . \varepsilon V$ & مكان السكن \\
\hline$\ldots \ldots$ & rq.А1 & r & $\leq Y .9 \leq$ & $\wedge \odot . \wedge \wedge$ & المؤهل \\
\hline
\end{tabular}

ه يلاحظ من الجدول السابق أن هناك فروقًا ذات دلالة إحصائية لهجال

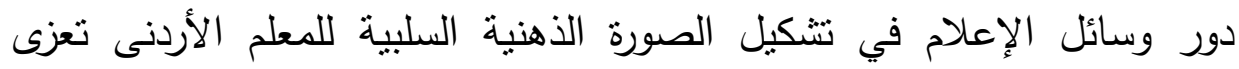

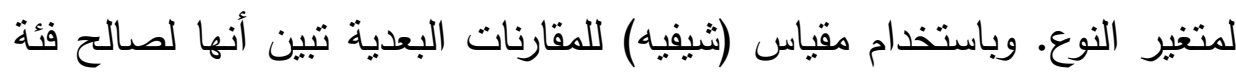
النوع (ذكر ) صاحبة المتوسط الحسابي الأعلى مقارنة بفئة (أنثى).

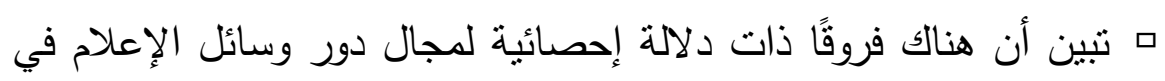
تثكيل الصورة الذهنية السلبية للمعلم الأردنى تعزى لمتغير العمر ـ وباستخدام

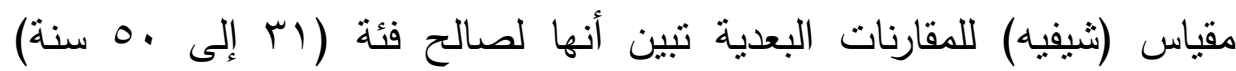

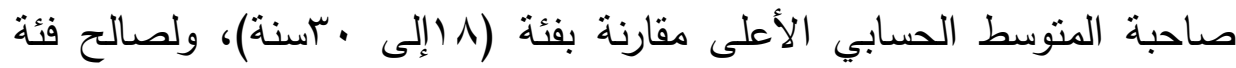

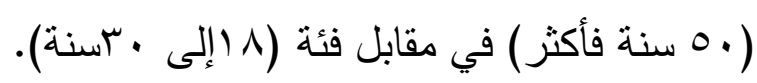

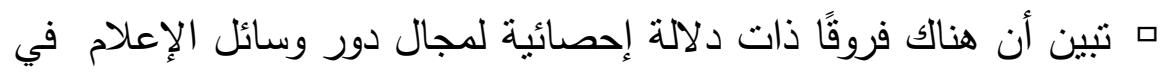
تشكيل الصورة الذهنية السلبية للمعلم الأردنى تعزى لمتغير الحالة الاجتماعية. 


\section{الصورة الأهنية للمعلم}

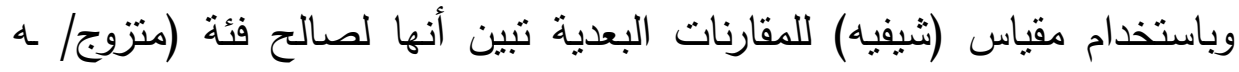

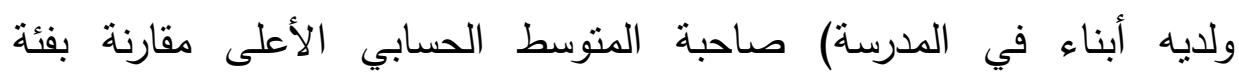
(أعزب/عزباء).

ه نبين أن هناك فروقًا ذات دلالة إحصائية لمجال دور وسائل الإعلام في

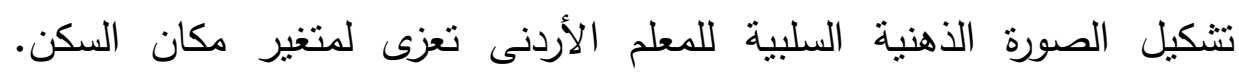
وباستخدام مقياس (شيفيه) للمقارنات البعدية تبين أنها لصالح فئة السكن (مدينة) صاحبة المتوسط الحسابي الأعلى مقارنة بفئة (قرية/ريف).

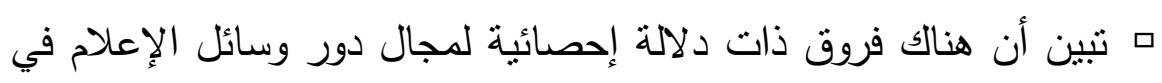
تثكيل الصورة الذهنية السلبية للمعلم الأردنى تعزى لمتغير المستوى العلى العلمي.

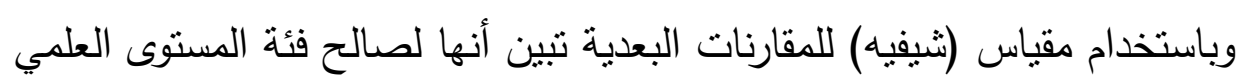

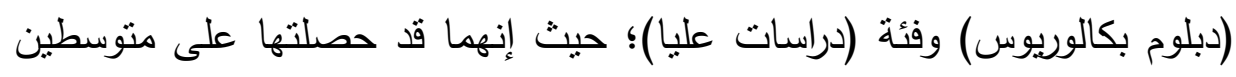
مرتفعين في مقابل فئة (ثانوية عامة فأقل). نتائج الإجابة عن السؤال الرابع:

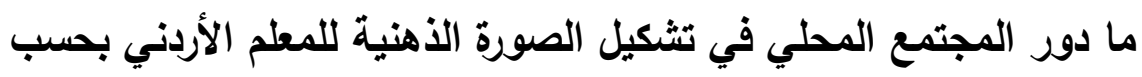
المتغيرات الايمغرافية (الجنس/العمر / مستوى التعليم)؟

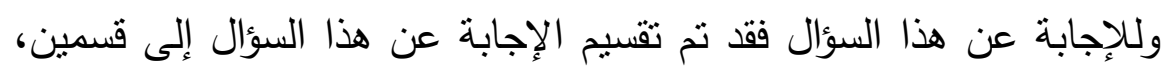

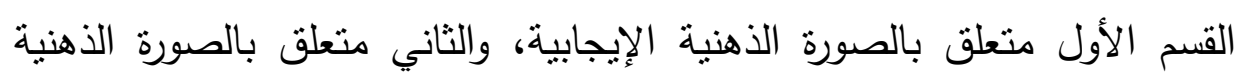

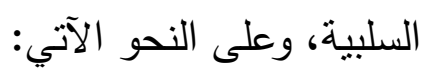
أولاً: دور المجتمع المحلي في تثكيل الصورة الذهنية الإيجابية للمعلم الأردني: تم استخراج المتوسطات الحسابية والانحرافات المعيارية للإجابات التي

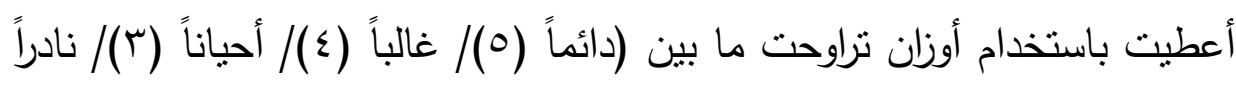

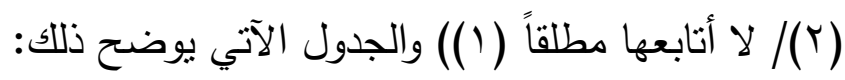




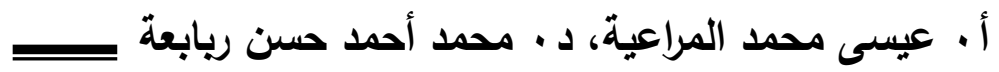

\section{جدول رقم (r I )}

المتوسطات الحسابية والانحرافات المعيارية والنسب المئوية لمجال دور المجتمع المحلي في تثكيل الصورة الذهنية الإيجابية للمعلم الأردني

\begin{tabular}{|c|c|c|c|c|}
\hline النسبة \% & الانحراف & الحستيط & مجالات الدراسة & ال الرقم \\
\hline$\vee q$ & $\cdot . \wedge 7 \pi$ & $r .90$ & ينظر إلى المعلم نظرة احترام وتقدير . & .1 \\
\hline$\vee \wedge . \wedge$ &. .110 & r.A9 & المعلم. &.$r$ \\
\hline$V \varepsilon . r$ & $1 . .1$ & $r . v)$ & يقدر مهنة التعليم ويحترم المعلمين. & r \\
\hline VY.T &. .914 & $r .7 r$ & وإعطائه المكانة اللائقة به. احترام المعلم & ع. \\
\hline 71.7 & $1 . .1$ & $r . \varepsilon r$ & وتقديره الطلبة على احترام المعلم & .0 \\
\hline TV.E & 1 & r.TV & 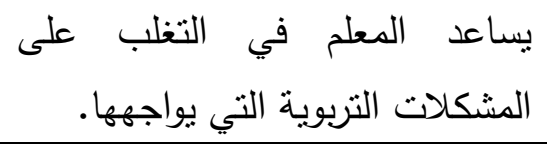 & .7 \\
\hline$T V . \varepsilon$ & 1 & r.TV & يتبنى قضايا المعلم ويدافع عنها. &.$\vee$ \\
\hline 71.7 & $1 . . v$ & $r . . \wedge$ & الرسالة التي يؤديها. &.$\wedge$ \\
\hline 71.7 & $1.1 \varepsilon$ & $r . . \Lambda$ & وجهوده أبناءه عن مكانة المعلم & .9 \\
\hline 09.4 & 1.17 & r.97 & العامة. المعلم ويصدره في المناسبات & .1. \\
\hline $0 \wedge . \wedge$ & 1.14 & r. $9 \varepsilon$ & بدعبادراته. المجتمع أفكار المعلم ويهتم & .11 \\
\hline 01.7 & $1 . r 4$ & r.9 & معلجين أبناءه في المستقبل ليصبحوا & \\
\hline
\end{tabular}




\begin{tabular}{|c|c|c|c|c|}
\hline 07.7 & 1.17 & r.Ar & المشاور المعلم ويرجع إليه في قضايا & r \\
\hline 00.1 & 1.17 & r.Vq & المعرلم. على تتظيم مبادرات لتكريم & $.1 \leq$ \\
\hline 70.7 &.$\wedge \wedge 1$ & r.r & المجال الكلي & \\
\hline
\end{tabular}

$$
\text { تبين من الجدول السابق الآتي: }
$$

تراوحت الفقرات التي تمت الإجابة عنها في هذا المجال في منوسطاتها

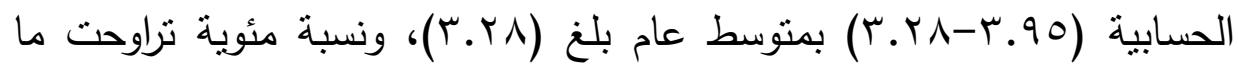

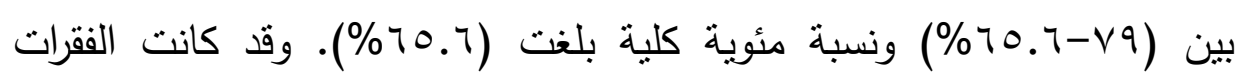
الخمس الأولى التي حصلت على أعلى المتوسطات هي: (بنظر إلى المعلم نظرة

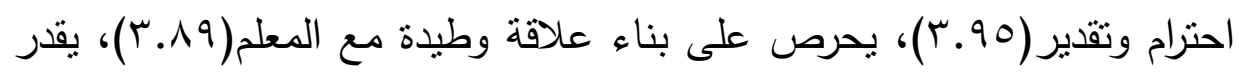
مهنة التعليم ويحترم المعلمين( (Y.Y)، يدعو المواطنين إلى احترام المعلم وإعطائه بـاء

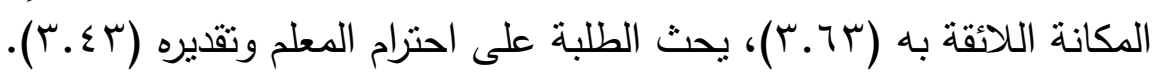
وللتعرف على وجود فروق معنوية بين المتغيرات، فقد تم إجراء تحليل التباين

$$
\text { الأحادي، وعلى النحو الآتي: }
$$

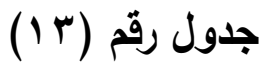

نتائج تحليل التباين لأثز متغيرات (النوع/العمر/ الحالة الاجتماعية/ مكان

\begin{tabular}{|c|c|c|c|c|c|}
\hline مستوى الدلالة & قيمة ف & درجات & متوسط المربعات & المربعات & المتغير \\
\hline$. r \mid r$ & 1.00 & 1 & 1.41 & $1 . Y 1$ & النوع \\
\hline$* \ldots$ & $\varepsilon \wedge .\urcorner$. & r & $r \varepsilon .10$ & $7 \Lambda . r$ & العمر \\
\hline *.... & 111.1. & r & . & YV.rI & الإضع \\
\hline
\end{tabular}

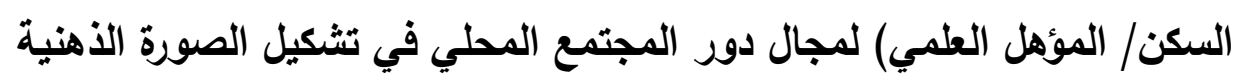




\begin{tabular}{|c|c|c|c|c|c|}
\hline$* \ldots \ldots$ & $1 \leq .10$ & $r$ & $11 . . v$ & דצ.r" & مكان \\
\hline$* \ldots \ldots$ & rᄉ. 10 & $r$ & YV.T. & $00 . Y_{1}$ & العؤهل \\
\hline
\end{tabular}

يلاحظ من الجدول السابق أن هناك فروقًا ذات دلالة إحصائية لمجال دور المجتمع المحلي في تشكيل الصورة الذهنية الإيجابية للمعلم الأردنى تعزى لمتغير العدر • وباستخدام مقياس (شيفيه) للمقارنات البعدية تبين أنها لصالح فئة العمر (1) إلى • ب سنة) صاحبة المتوسط الحسابي الأعلى مقارنة بالفئنين الأخربين

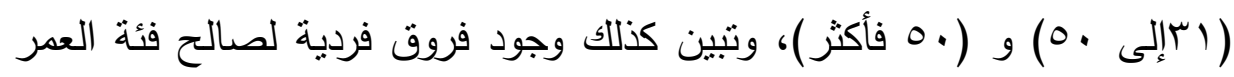
(اس-.0.0) في مقابل فئة ( • مفأكثر). ه تبين أن هناك فروقًا ذات دلالة إحصائية لمجال دور المجتمع المحلي في تشكيل الصورة الذهنية الإيجابية للمعلم الأردنى تعزى لمتغير الحالة الاجتماعية. وباستخدام مقياس (ثيفيه) للمقارنات البعدية تبين أنها لصالح فئة (أعزب/عزباء) صاحبة المتوسط الحسابي الأعلى مقارنة بالفئة (متزوج/هه وله أبناء)، وكذلك بين فئة (متزوج//ه وليس لديه/ا أبناء) صاحبة المتوسط الحسابي الأعلى مقارنة بالفئة (متزوج/اه وله أبناء). ه تبين أن هناك فروقًا ذات دلالة إحصائية لمجال دور المجتمع المحلي في تشكيل الصورة الذهنية الإيجابية للمعلم الأردنى تعزى لمتغير مكان السكن. وباستخدام مقياس (ثيفيه) للمقارنات البعدية تبين أنها لصالح فئة السكن (قربة/ريف) صاحبة المتوسط الحسابي الأعلى مقارنة بفئة (مدينة)، وكذلك وجود فروق ذات دلالة إحصائية لصالح فئة (بادية) في مقابل فئة (مدينة). ه تبين أن هناك فروقًا ذات دلالة إحصائية لمجال دور المجتمع المحلي في تشكيل الصورة الذهنية الإيجابية للمعلم الأردنى تعزى لمتغير المستوى العلمي. وباستخدام مقياس (ثيفيه) للمقارنات البعدية نيين أنها لصالح فئة (ثانوية فأقل) 


\section{الصورة الذهنية للمعلم}

صاحبة المتوسط الحسابي الأعلى مقارنة بالفئتين الأخريين (دبلوم/بكالوريوس) و (دراسات عليا).

ثانياً: دور المجتمع المحلي في تثكيل الصورة الذهنية السلبية للمعلم الأردني:

نم استخراج المتوسطات الحسابية والانحرافات المعيارية للإجابات التي

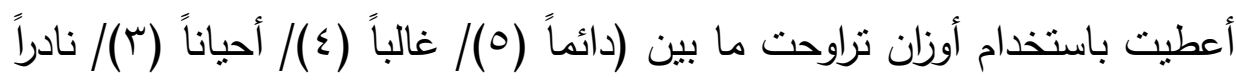

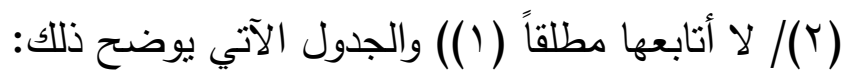

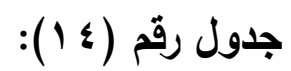

المتوسطات الحسابية والانحرافات المعيارية وإلنسب المئوية لمجال دور المجتمع المحلي في تثكيل الصورة الذهنية السلبية للمعلم الأردني

\begin{tabular}{|c|c|c|c|c|}
\hline النسبة \% & الانحراف & الحسابي الحتوسط & 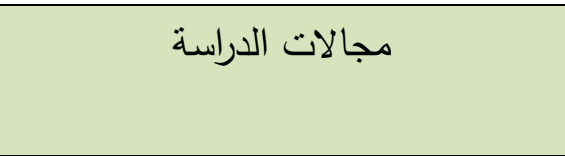 & 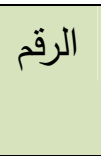 \\
\hline 7.1 & 1.19 & $r . .9$ & بيتطبد الضوء على تصرفات المعلم & . \\
\hline 71.7 & $1.1 r$ & r.. & ويتغافل عن الوقوف بجانب المعلم & . \\
\hline $71 . \varepsilon$ & 1.10 & $r . \cdot v$ & يحرج المعلم بتقديم الثكاوى ضده & r \\
\hline ov.乏 & $1 . .1$ & r.AV & يتحدث عن المعلم وينتقده بشكل سلبي &.$\varepsilon$ \\
\hline 07.1 & $1 . r$. & 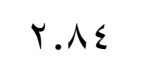 & يتجاهل دور المعلم ويقلل من شأنه & .0 \\
\hline $0 \leqslant .7$ & $1 . r 1$ & r.VT & ضدجّع الطلبة ضد المعلم ويناصره & .7 \\
\hline $0 \leqslant .7$ & $1.1 \mathrm{~V}$ & t.Vr & يتاقل صور ومقاطع مسيئة للمعلم & $\cdot v$ \\
\hline O . . & 1.17 & r.VI & لال يحترم مكانة المعلم في المحافل &.$\wedge$ \\
\hline
\end{tabular}




\begin{tabular}{|c|c|c|c|c|}
\hline $0 \varepsilon$ & 1.10 & Y.V. & وُضِمن الحديث عن المعلم بالنكت & .9 \\
\hline or.A & 1.10 & Y..$\varepsilon$ & ينظر الى المعلم نظرة دونية & .1 . \\
\hline ov & 1 & Y.AO & المجال الكلي & \\
\hline
\end{tabular}

$$
\text { تنين من الجدول السابق الآتي: }
$$

تراوحت الفقرات التي تمت الإجابة عنها في هذا المجات المجال في منوسطاتها

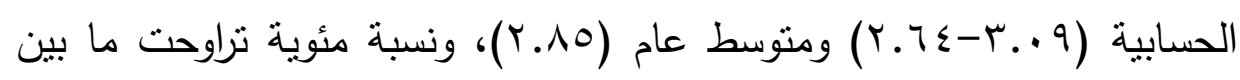

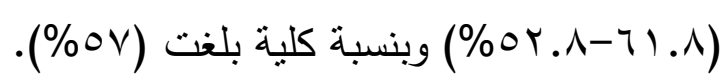

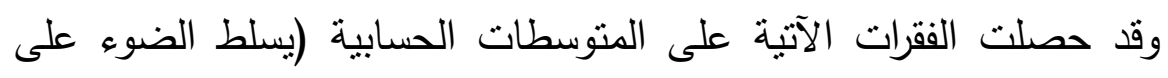

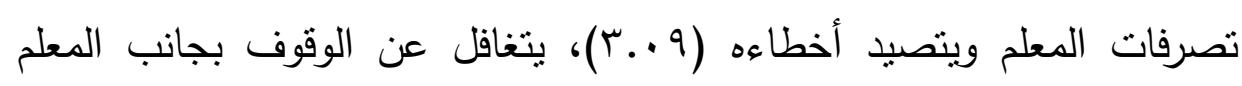

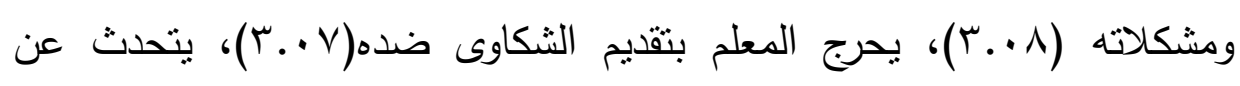

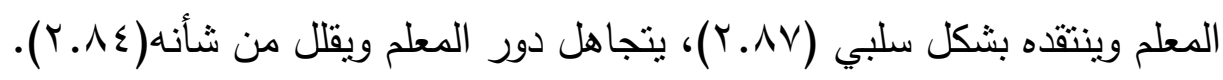
وللتعرف على وجود فروق معنوية بين المتغيرات، فقد نم إجراء تحليل التباين

$$
\text { الأحادي، وعلى النحو الآتي: }
$$

$$
\text { جدول رقم (10) }
$$

\begin{tabular}{|c|c|c|c|c|c|}
\hline \multicolumn{6}{|c|}{ السلبية للمعلم الأردني } \\
\hline مستوى الدلالة & قيمة ف & درجات & متوسط & المربعات & المتغير \\
\hline . TOY & $\cdot . T \cdot \varepsilon$ & 1 & $\cdot r \cdot \Lambda$ & $\cdot \cdot r \cdot \Lambda$ & النوع \\
\hline$* \ldots$ & $10 . Y \leqslant$ & r & 10.1 & $r . .19$ & العمر - (العر \\
\hline$* \ldots$... & T.TV & r & r.V & $V . \varepsilon r$ & الاجتماعي \\
\hline
\end{tabular}

نتائج تحليل التباين لأثر متغيرات (النوع/العمر/ الحالة الاجتماعية/ مكان

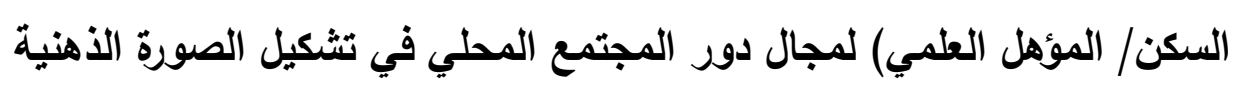




\begin{tabular}{|c|c|c|c|c|c|}
\hline$* \ldots \ldots$ & A.r. & $r$ & $\Lambda . \Gamma \varepsilon$ & ro & مكان السكن \\
\hline$* \ldots$ & 17.r. & $r$ & $17 .+r$ & Tr..E & المؤهل \\
\hline
\end{tabular}
تشكيل الصورة الذهنية السلبية للمعلم الأردنى تعزى لمتغير العمر. وباستخدام مقياس (شيفيه) للمقارنات البعدية تبين أنها لصالح فئة ( • بإلى • مسنة) صاحبة المتوسط الحسابي الأعلى مقارنة بفئة (1/ إلى .r سنة)، وكذلك وجود فروق ذات دلالة إحصائية لصالح فئة ( • م سنة فأكثر) في مقابل فئة (1 ا- ـ اسنة). ه تبين أن هناك فروقًا ذات دلالة إحصائية لمجال دور المجتمع المحلي في تشكيل الصورة الذهنية السلبية للمعلم الأردنى تعزى لمتغير الحالة الاجتماعية. وباستخدام مقياس (LSD) للمقارنات البعدية تبين أنها لصالح فئة (متزوج/ لة ولديه أبناء في المدرسة) صاحبة المتوسط الحسابي الأعلى مقارنة بفئة (أعزب/عزباء) وفئة (متزوج/اه وليس لديه أبناء في المدرسة). ه تبين أن هناك فروقًا ذات دلالة إحصائية لمجال دور المجتمع المحلي في ولي تشكيل الصورة الذهنية السلبية للمعلم الأردنى تعزى لمتغير مكان السكن. وباستخدام مقياس (ثيفيه) للمقارنات البعدية تبين أنها لصالح فئة السكن (مدينة) صاحبة المتوسط الحسابي الأعلى مقارنة بفئة (قرية/ريف)، وكذلك لصالح فئة السكن (مدينة) في مقابل فئة (بادية). ه تبين أن هناك فروقًا ذات دلالة إحصائية لمجال دور المجتمع المحلي في تشكيل الصورة الذهنية السلبية للمعلم الأردنى تعزى لمتغير المستوى العلمي. وباستخدام مقياس (شيفيه) للمقارنات البعدية تبين أنها لصالح فئة المستوى العلمي (دبلوم/ بكالوريوس) وفئة (دراسات عليا)؛ حيث إنهما حصلتها على متوسطين مرتفعين في مقابل فئة (ثانوية عامة فأقل). 


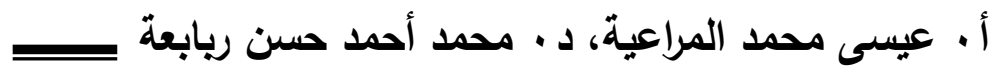

مناقثة التتائج والتوصيات:

يتتاول هذا الفصل عرضاً لمناقتة النتائج التي توصلت إليها هذه الدراسة في ضوء أسئلتها، والتي هدفت إلى التعرف إلى الصورة الذهنية للمعلم الأردني، ودور وسائل الإعلام من جهة والمجتمع المحلي من جهة أخرى في تشكليها. وما إذا كان هنالك علاقة ذات دلالة إحصائية بين المتغيرات الديمغرافية (النوع/العمر/مكان الحالة الاجتماعية/مكان السكن/المستوى العلمي). ويتضمن هذا الفصل أيضاً التوصيات التي توصل إليها الباحثان في ضوء نتائج هذه الدراسة، وسيتم عرض نتائج الدراسة وفقاً لأسئلتها، وعلى النحو الآتي: أولاً: مناقثة التتائج المتعلقة بالإجابة عن السؤال الأول: ما طبيعة متابعة المبحوثين للموضوعات الخاصة بالمعلم الأردني في وسائل الإعلام الأردنية بحسب المتغيرات الديمغرافية (الجنس/العمر / مستوى التعليم)؟ فقد أوضحت نتائج التحليل الإحصائي حصول الفقرات التي يتكون منها مجال طبيعة متابعة المبحوثين للموضوعات الخاصة بالمعلم الأردني في وسائل

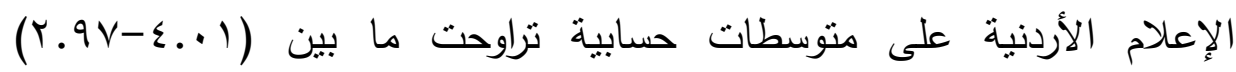

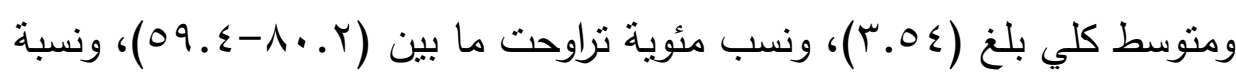
عامة بلغت (^. • V\%\%). والناظر في هذه المتوسطات وما يقابلها من نسب مئوية تعبر عنها، يجد أن غالبيتها جاء مرتفعاً، وأن كافة الفقرات قد حصلت على هـ متوسطات جاءت أعلى من الوسط (ب)، باستنثاء فقرة واحدة والتي أخذت الترتيب الأخير، والتي نصت على (أتابع الصحف الرسمية لمعرفة ما ينُشر عن المعلم الأردني)؛ حيث حصلت على متوسط (Y.9V) ونسبة بلغت (ع.09)، ولعل صدق أفراد العينة في الإجابة عن هذه الفقرة كان واضحاً من حيث إن متابعة الصحف الرسمية لم يعد كالسابق، حيث تعددت وسائل الإعلام وتكاثرت، ولم يعد للصحافة الورقية المكانة التي كانت تحظى بها سابقاً. 


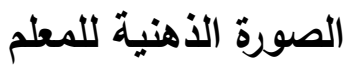

أما بقية الفقرات فإنها تدل دلالة واضحة على أن غالبية أفراد العينة يقومون

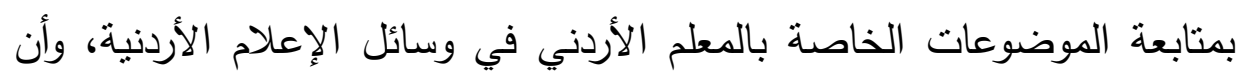

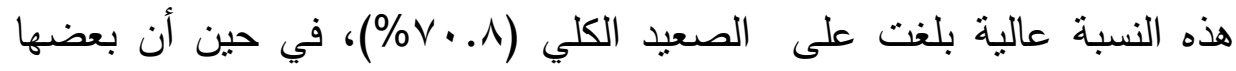

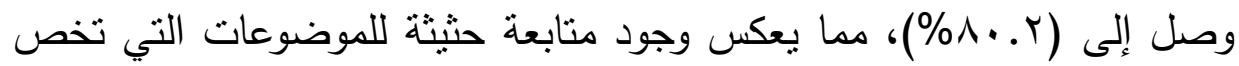

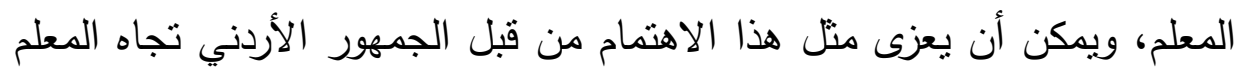

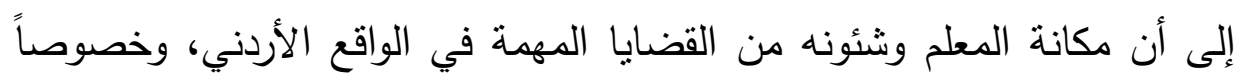

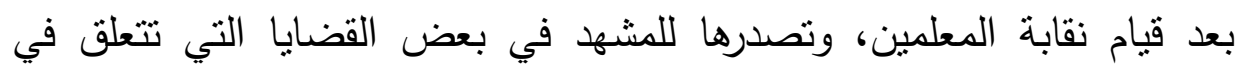
مجال التربية والتعليم، وآخرها الإضراب العام عن التدريس الذي نفذته النقابة

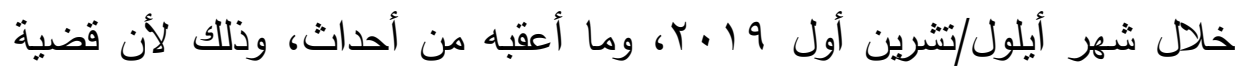

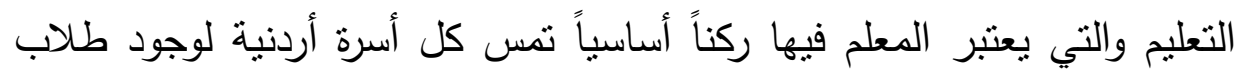
وطالبات ينتمون لهذه الأسر من قريب أو بعيد، وبالتالي أصبحت شئئون المعلمين

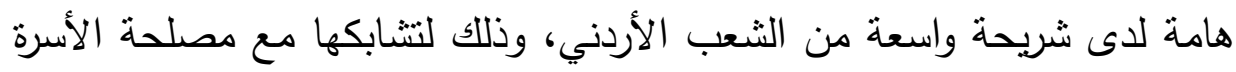
التي تشنمل في المجمل على أفراد يدرسون في المدارس الحكومية أو الخاصة. وللتعرف على وجود فروق معنوية بين المتغيرات الديمغرافية التي تتعلق

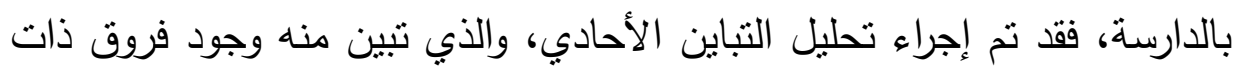
دلالة إحصائية على طبيعة منابعة المبحوثين للموضوعات الخاصة بالمعلم

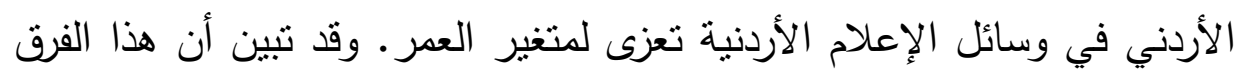

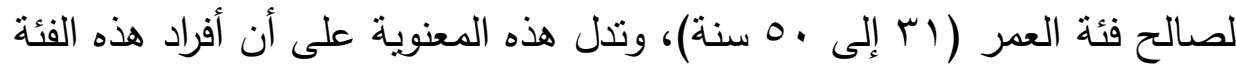

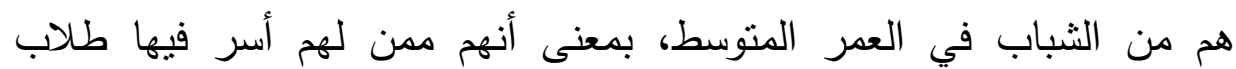

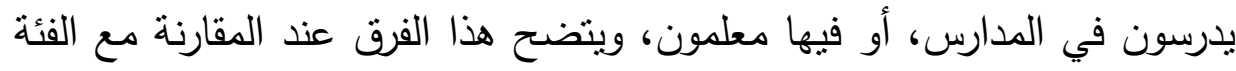

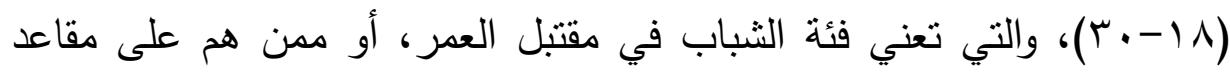

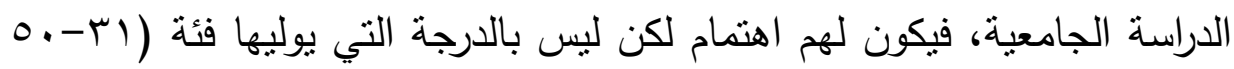

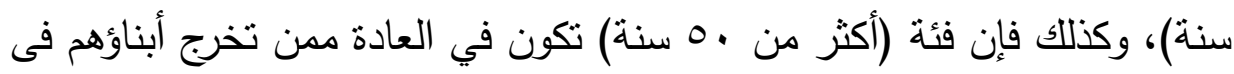




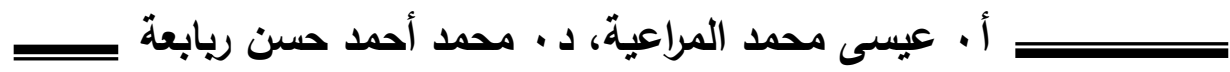
المدرسة، وانتقلا إلى المرحلة الجامعية، وبالثالي يكون اهنمامهم بموضوعات المعلمين وقضاياها أقل من غيرهم. وتبين كذللك عدم وجود فروق ذات دلالة إحصائية بين فئات متغيرات الدراسة (النوع، الوضع الاجتماعي، مكان السكن، المستوى العلمي)، بمعنى آخر أن فئات

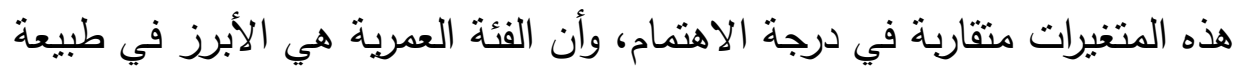
المتابعة بين الفئات العمرية الأخرى.

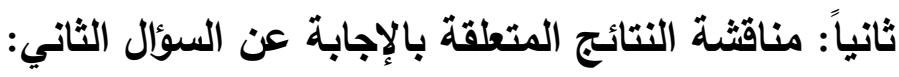

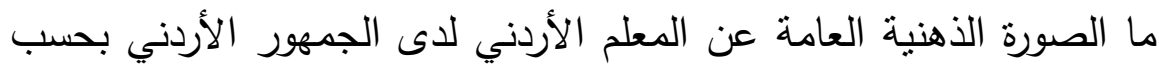
المتغيرات الديمغرافية (الجنس/العمر / مسنوى التعليم)؟

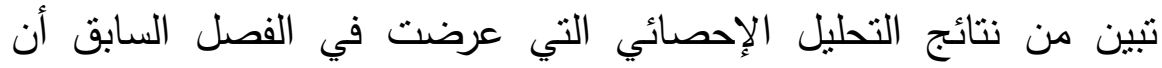
الفقرات الني يتكون منها مجال الصورة الذهنية العامة عن المعلم الأردني لدى لإى لفي

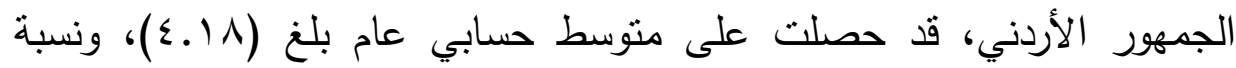

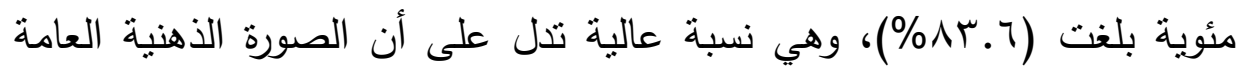

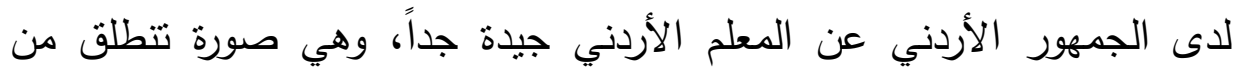

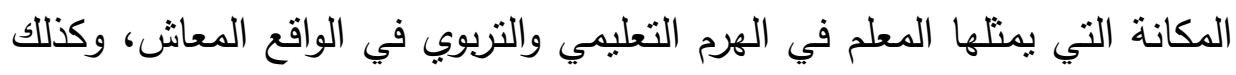

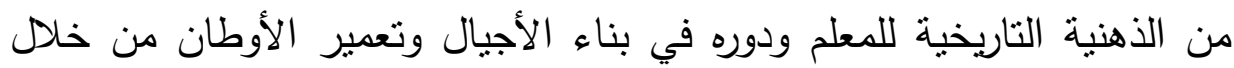
تتشئة الثباب على مدى عقود طويلة أدت إلى حصول نهضة تعليمية متميزة

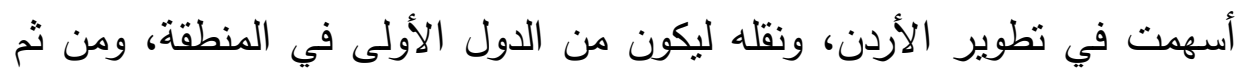
العالم في نسبة التعليم ومكافحة الأمية. وللتعرف على وجود فروق معنوية بين المتغيرات الديمغرافية التي تتعلق

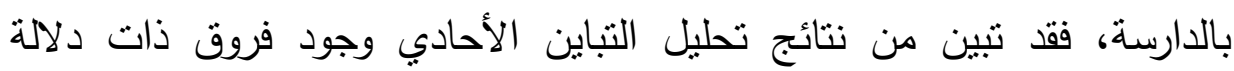

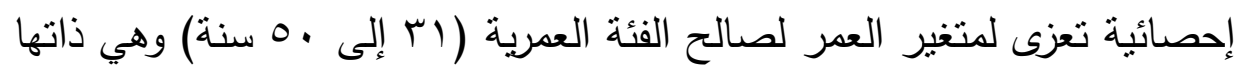

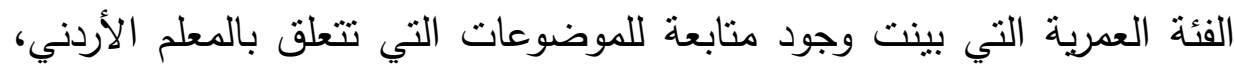
وتبين هذه النتيجة أن هذه الفئة ترى أن الجمهور الأردني يحمل صورة ذهنية للفئية 


\section{الصورة الأهنية للمعلم}

إيجابية عن المعلم الأردني. ويمكن أن يفسر هذا بكون هذه الثريحة العمرية أكثر

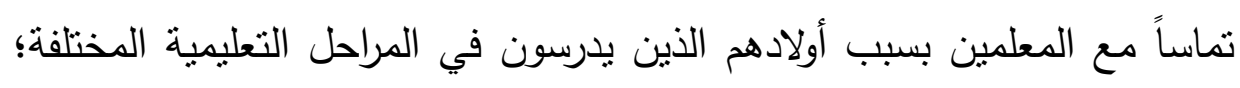
حيث يتواصل معهم الأهل من هذه الفئة العمرية بصورة أكبر من الفئات الأخرى.

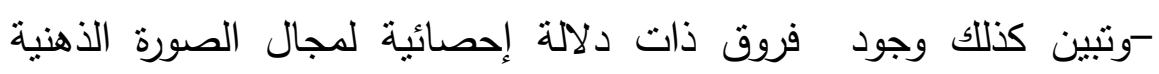

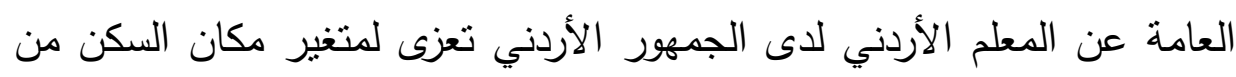

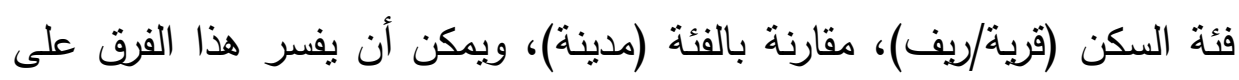

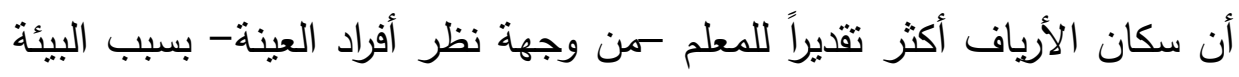

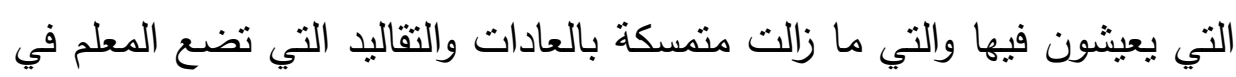

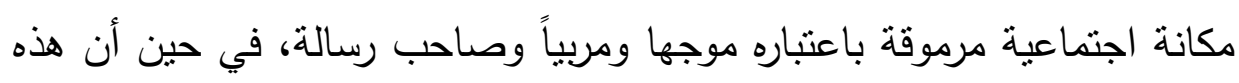

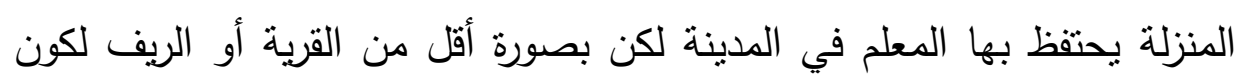
المدينة أكثر انفتاحاً والعلاقات الاجتماعية فيها أقل ترابطاً من القرية أو الريف.

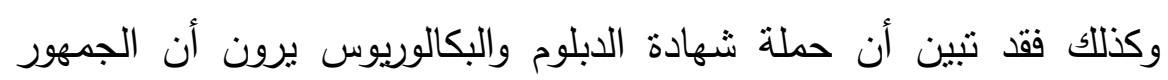

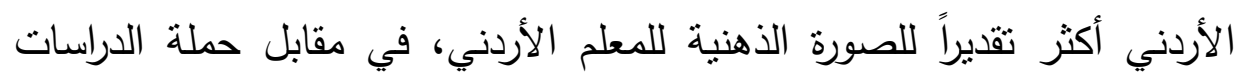

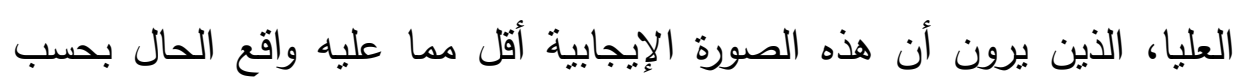

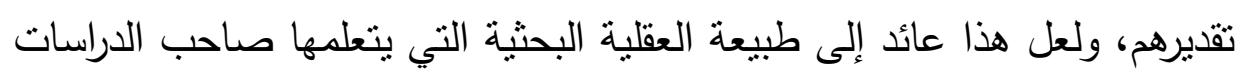
العليا، والتي تقوم على استخدام أساليب البحث العملي في النظر والاسنقراء

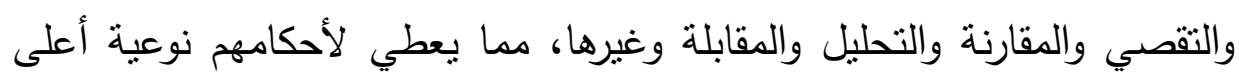
وقيمة أقرب للواقع، بعيداً عن العواطف والتعميمات. مع مع أن كلا الفئتين تريان

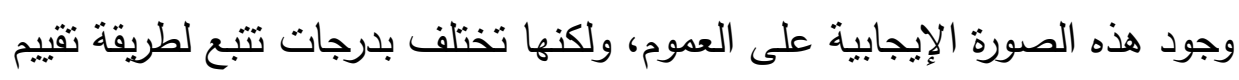
كل فئة لهذا الجانب. ثالثاً: مناقشة النتائج المتعلقة بالإجابة عن السؤال الثالث:

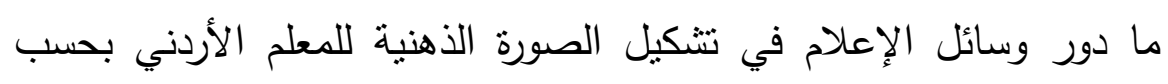
المتغيرات الديمغرافية (الجنس/العمر / مستوى التعليم)؟ دائل 


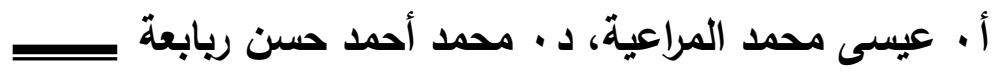

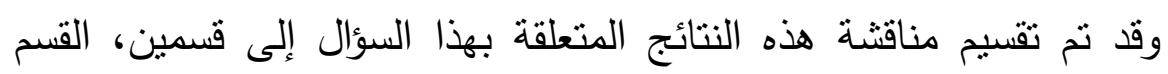
الأول متعلق بالصورة الذهنية الإيجابية، والثاني متعلق بالصورة الذهنية السلبية،

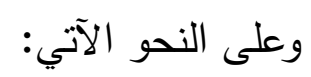

أولاً: مناقثة النتائج المتعقة بدور وسائل الإعلام في تثكيل الصورة الذهنية

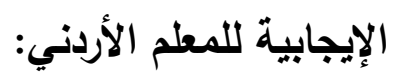

تبين من النتائج التي تم استخراجها في الفصل السابق أن الفقرات التي تمت

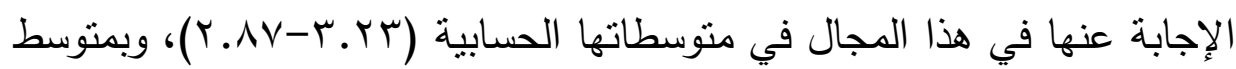

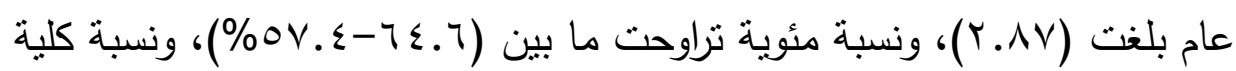

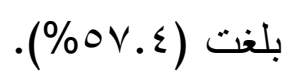

إن الناظر إلى فحوى هذا الدجال والمتعلق بدور وسائل الإعلام في تنشكيل الصورة الذهنية الإيجابية للمعلم الأردني يجد أن نسبة المساهمة في تنكيل

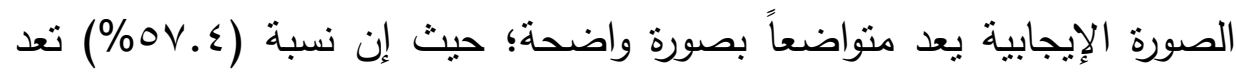
نسبة مقبولة لكنها منخفضة في ظل وجود انفتاح إعلامي، وتعدد في وسائل

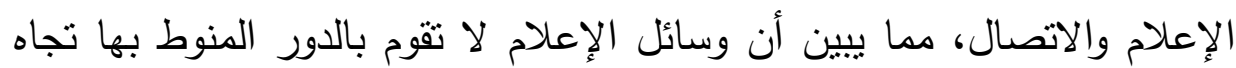

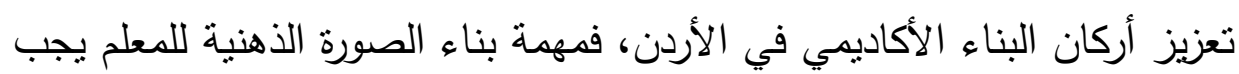

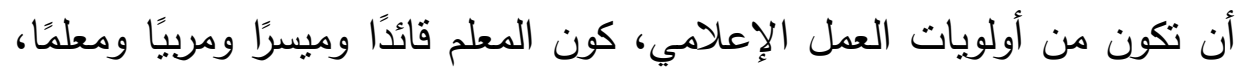

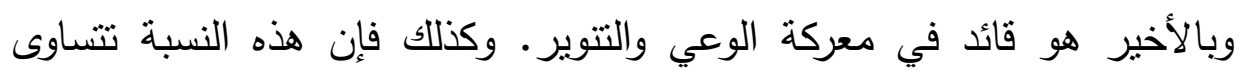

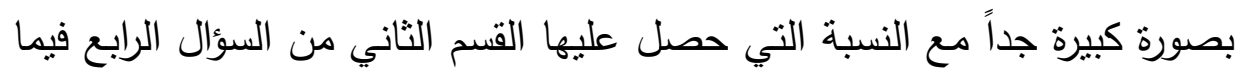
يتعلق بدور المجتمع في تنكيل صورة ذهنية سلبية عن المعلم الأردني، والتي جاءت (\%०\%)، مدا يؤكد وجود علاقة ارتباطية بين هذا المجال والمجال الدذكور، حيث إن انخفاض النسبة لدور وسائل الإعلام في هذا الجانب ينساوى الناطيه

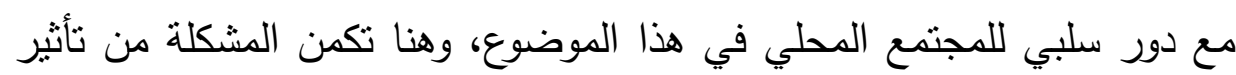
وسائل الإعلام بصورة سلبية في بعض موادها في هذا الاتجاه على الجمهور الأردني. 


\section{الصورة الذهنية للمعلم}

وقد تبين من نتائج تحليل التباين أن هناك فروقًا ذات دلالة إحصائية لهجال

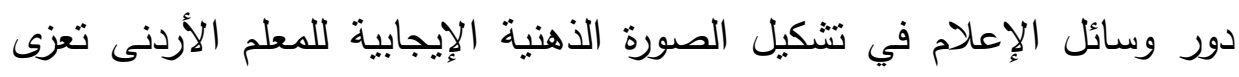

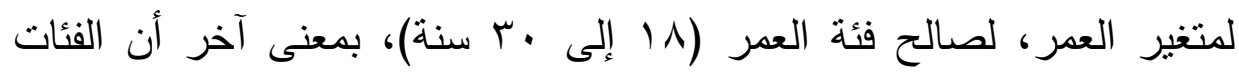

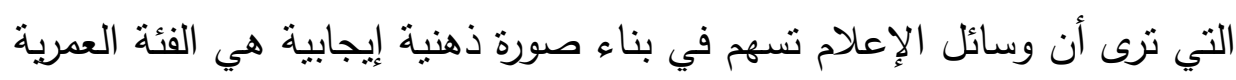

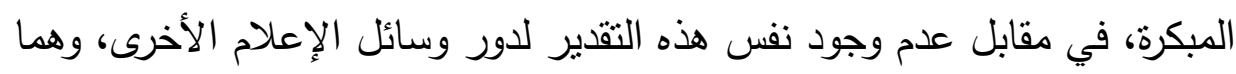

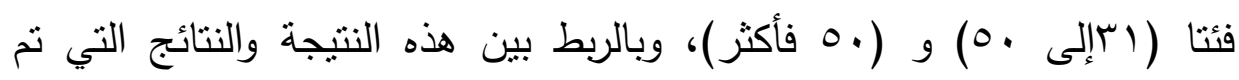

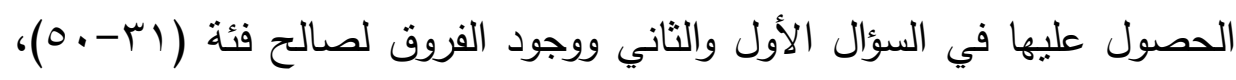

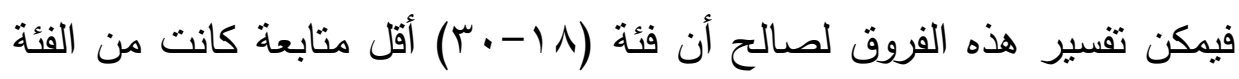

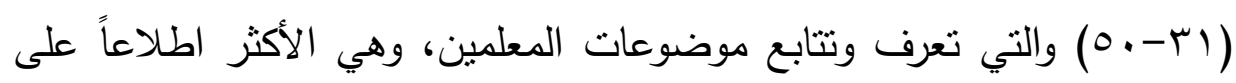

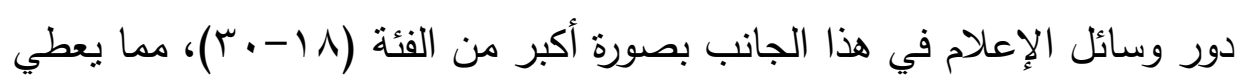
انطباعاً بأن هذه الفئة ترى أن ما تقدمه وسائل الإعلام يُعد كافياً بدرجة معينة ومناسباً لتقديم صورة إيجابية على الرغم من تدني نسبته المئوية.

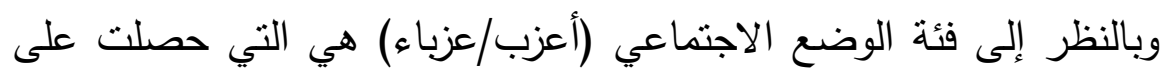

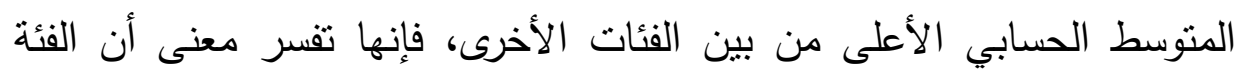

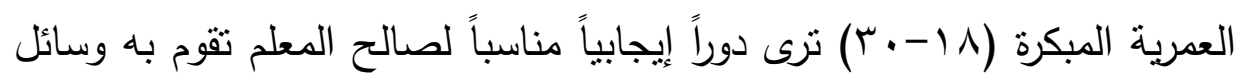

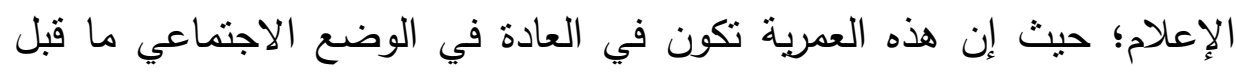

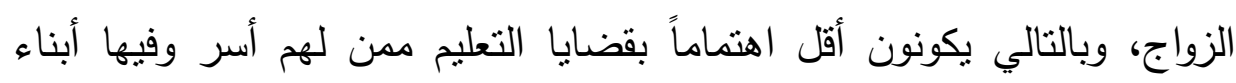
يذهبون للدراسة في المدارس. ه وتبين كذلك أن أفراد العينة من فئة السكن (قرية/ريف) وفئة (البادية)

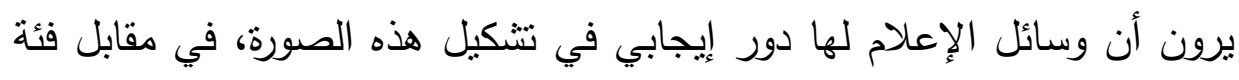

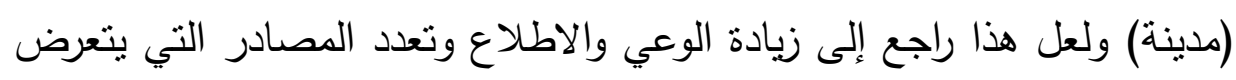

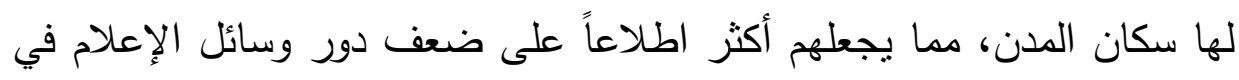
رسم الصورة الذهنية الإيجابية للمعلم. لمان. 


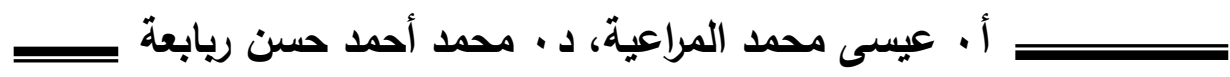

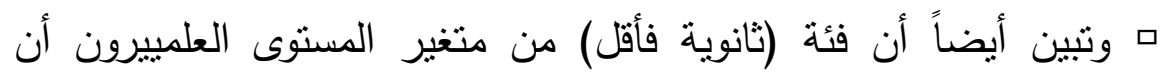

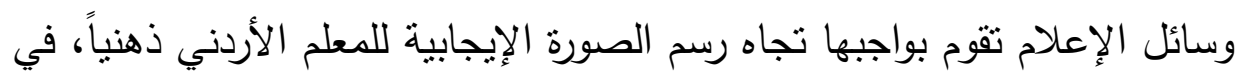

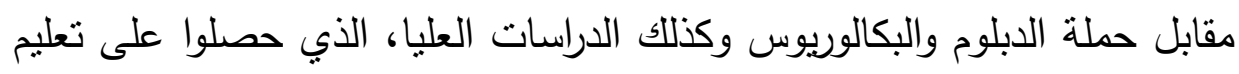
أعلى مما يجعلهم يدركون حجم التقصير الذي تقوم به وسائل الإعلام تجاه المعلم.

ثانياً: مناقثة النتائج المتعلقة بدور وسائل الإعلام في تثكيل الصورة الذهنية السلبية للمعلم الأردني: مانيه

من خلال النتائج التي تم عرضها في الفصني" السابق، فقد تنين أن

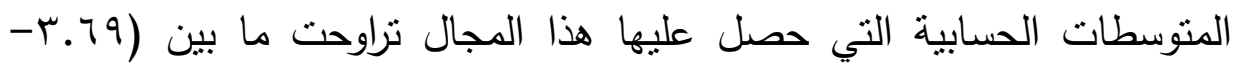

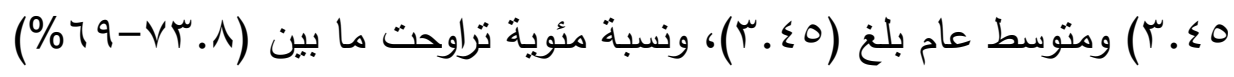

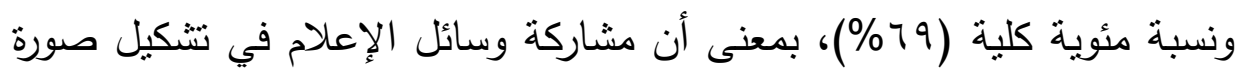

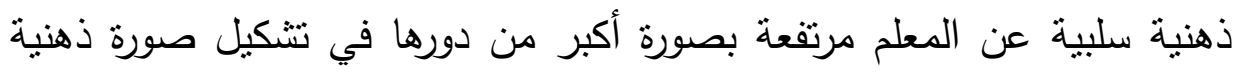
إيجابية.

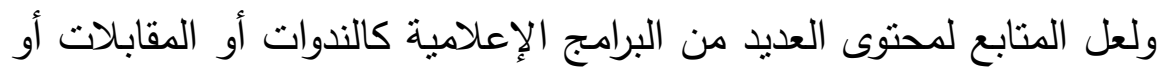

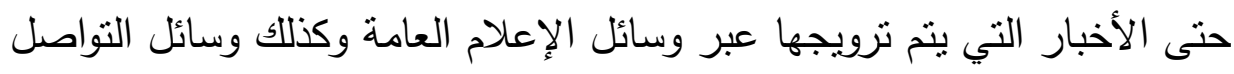

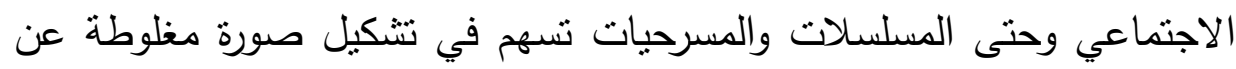
المعلم تظهره بمظهر الانتهازي الذي يريد أن بستولي على المال، ولا يقوم بواجبه،

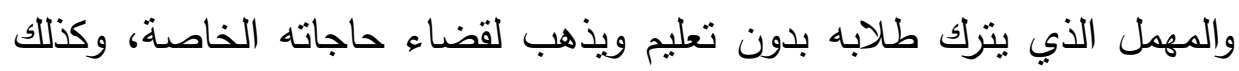

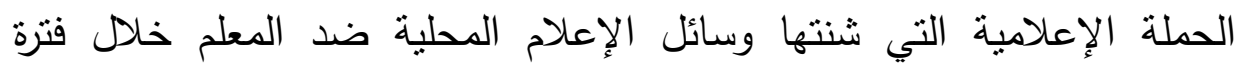
الإضراب في العام 9 ( ـ بم، وما سبقها من حملات أخرى خلال الأعوام السابقة

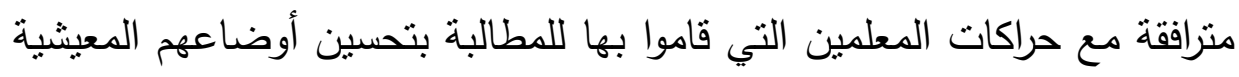

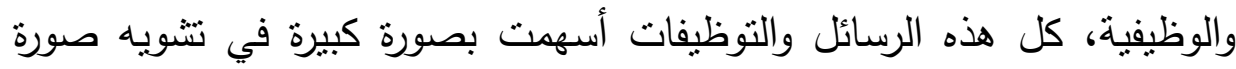
المعلم، والتقليل من شأنه ومكانته. 


\section{الصورة الذهنية للمطلم}

وبالنظر في نتائج تحليل التبابين للفروق بين المتغيرات فقد تبين أن فئة

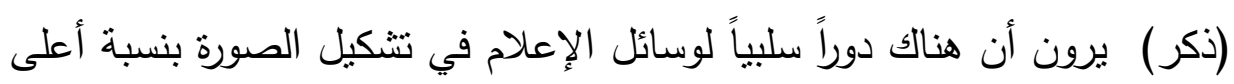

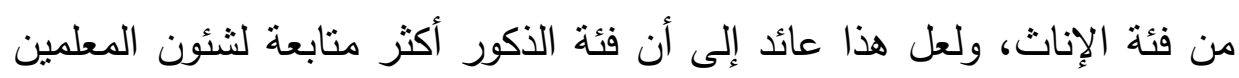

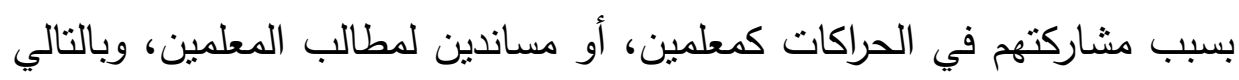

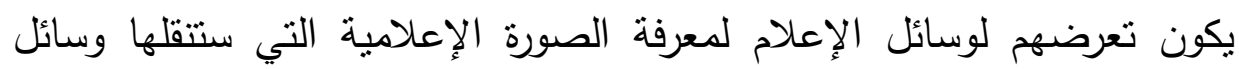

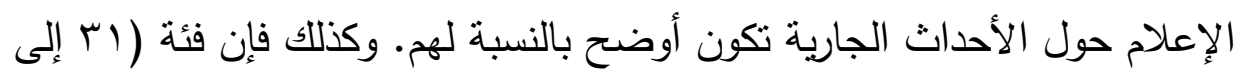

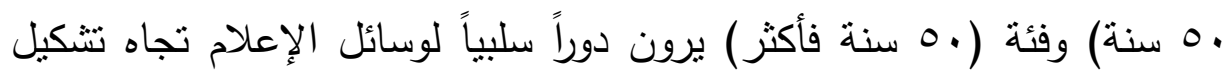

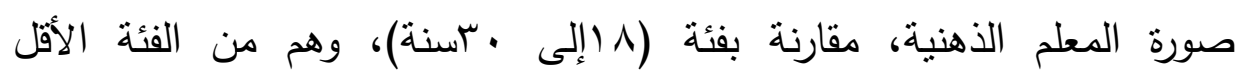

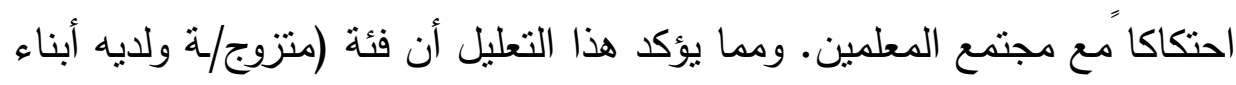

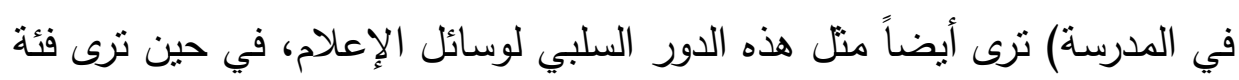
(أعزب/عزباء) غير ذلك.

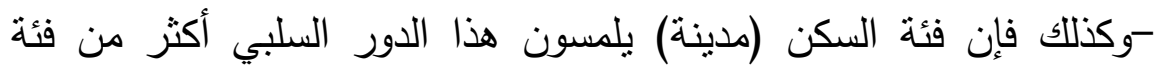

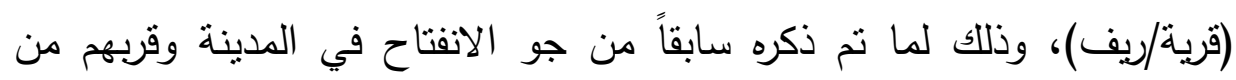

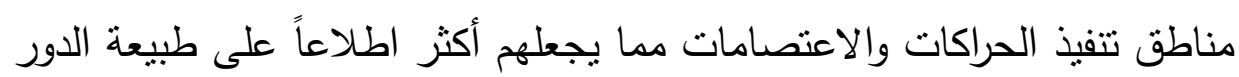
السلبي لوسائل الإعلام في هذا الاتجاه.

-وتبين كذللك أن متغير المستوى العلمي عند (دبلوم بكالوريوس) وفئة الأهاه (دراسات عليا)؛ حيث إنهما يدركان مدى سلبية الدور الذي تقوم به وسائل الإعلام

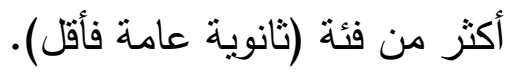

وعليه فإن فئات المتغيرات التي كانت أقل معرفة بالدور السلبي الذي تلعبه وسائل الإعلام في تتكيل الصورة الذهنية للمعلم هي الفئات من الإناث ومن الفئ الفئة الفئ

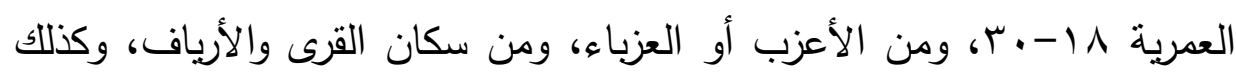
مستوى الثانوية العامة فأقلى، بعكس الفئات الأخرى. 


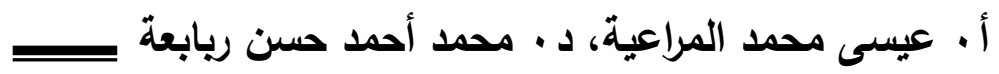

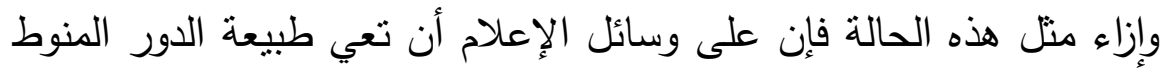

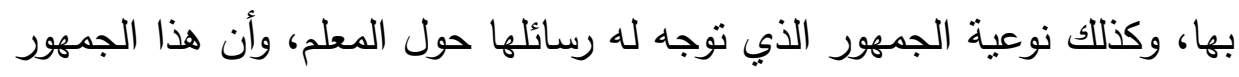

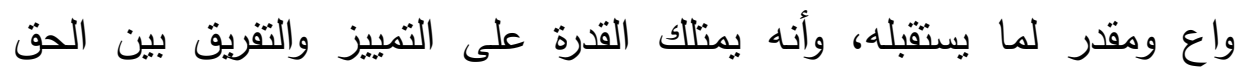

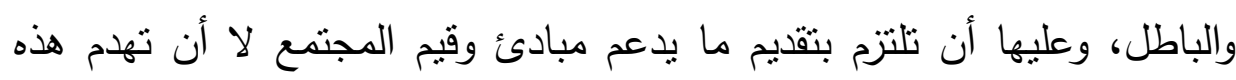
المبادئ والقيم وتسيء إلبها. رابعاً: مناقشة النتائج المتعلقة بالإجابة عن السؤال الرابع:

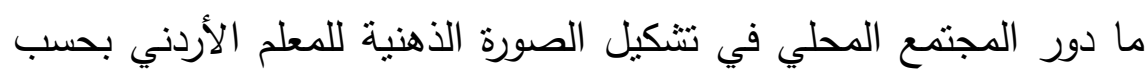

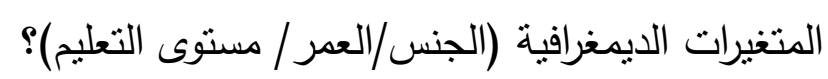

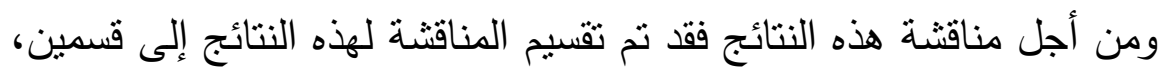
القسم الأول متعلق بالصورة الذهنية الإيجابية، والثاني متعلق بالصورة الذهنية الذانية

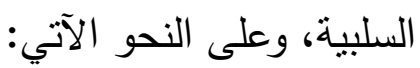

أولاً: مناقثة النتائج المتعلقة بدور المجتمع المحلي في تثكيل الصورة الذهنية

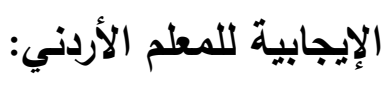

من خلال النتائج التي تم عرضها في الفصل الإني السابق فقد تراوحت الفقرات

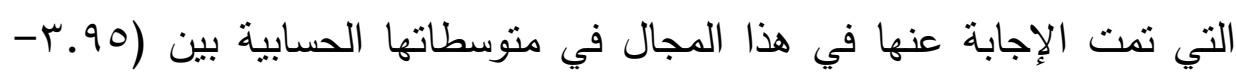

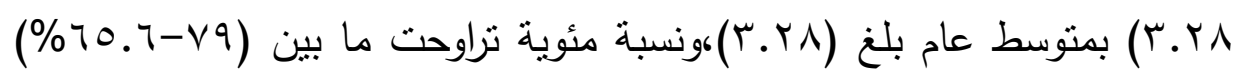

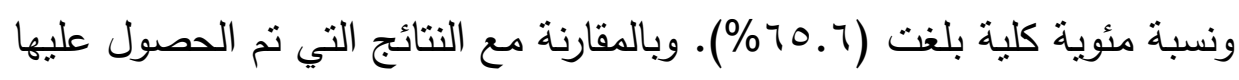

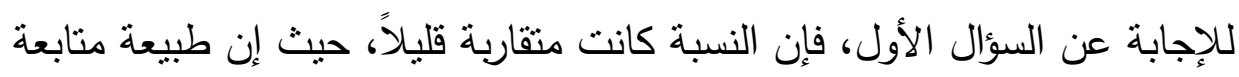

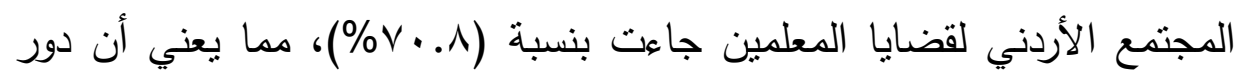
المجتمع في تنكيل صورة إيجابية يتقارب مع هذه النسبة، ويتأثر بها.

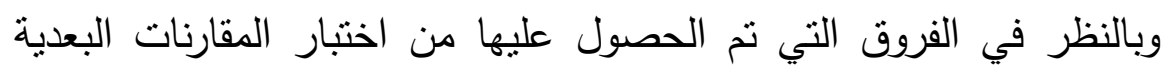

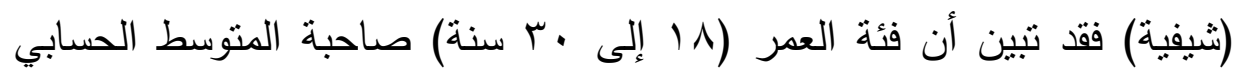

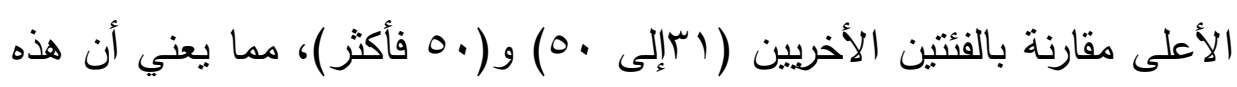

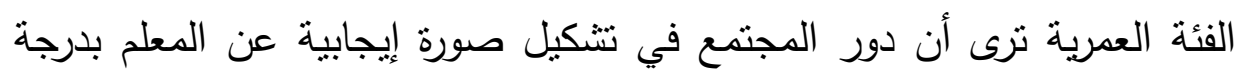




\section{الصورة الذهنية للمعلم}

أعلى من الفيتّن الأخريين، ولعل هذا عائد إلى أن أفراد هذه الفئة ما زالوا حديثي

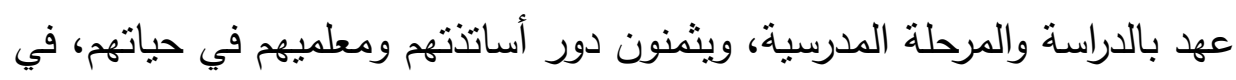
حين أن الفئتين الأخريين ممن لهم معرفة وخبرة واختلاط بشئون المجتمعات، ولئه

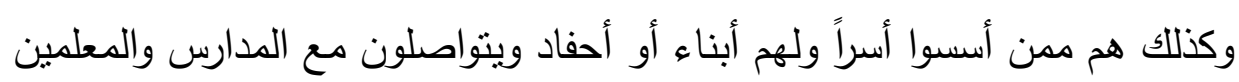

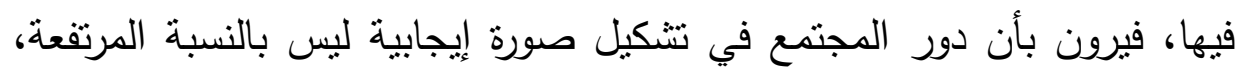
وذلك بحكم معرفتهم بالعديد من القضايا التي تثار ضد فئ المعلمين، وقد يتداخل فيها

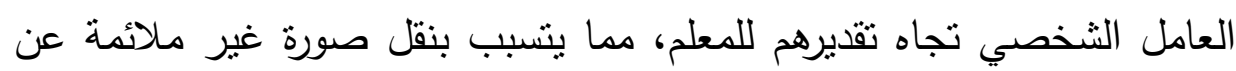
المعلم الأردني بصورة عامة. ويؤكد هذا التعليل نتيجة الفروق في متغير الحالة

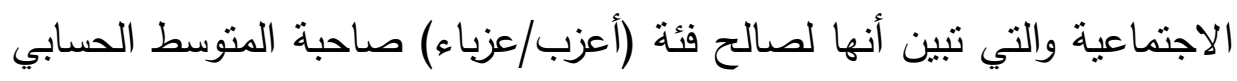

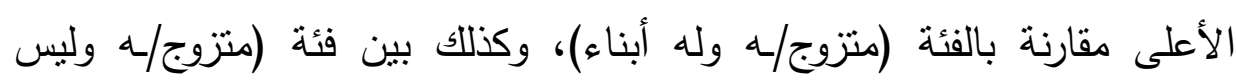

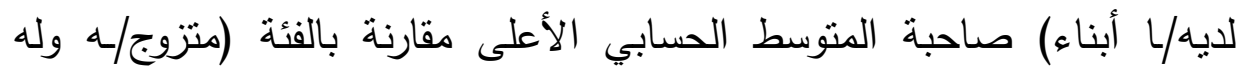

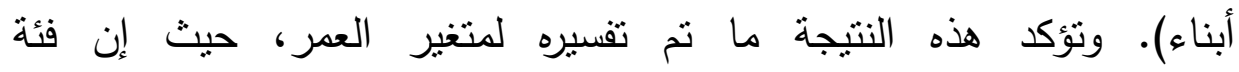
(أعزب/عزباء)، وكذلك (متزوج/هاه وليس لديه/ا أبناء)، هم من فئة غير متداخلين

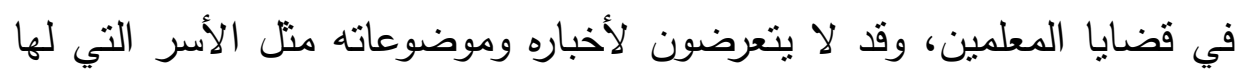

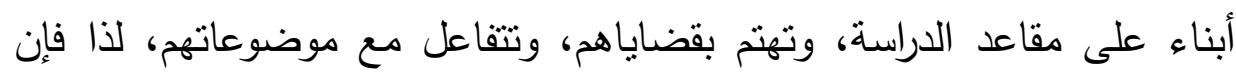

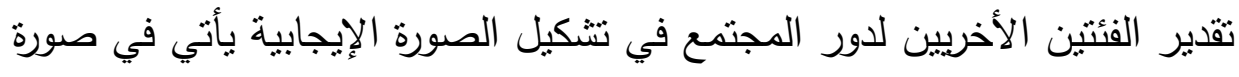

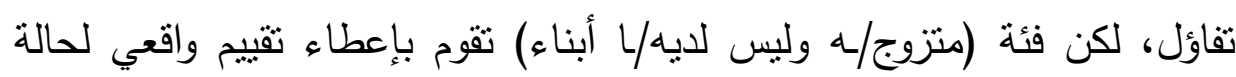
المجتمع بحكم التماس والاحتكالك مع مجتمع المدرسة ومتابعة تلاك الأخبار .

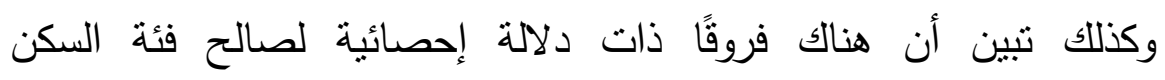

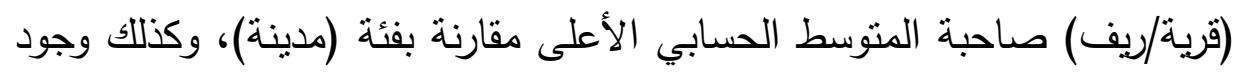

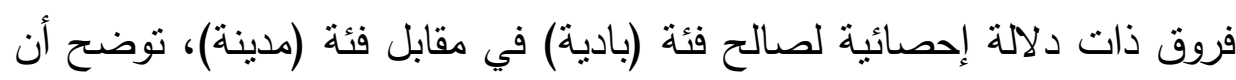

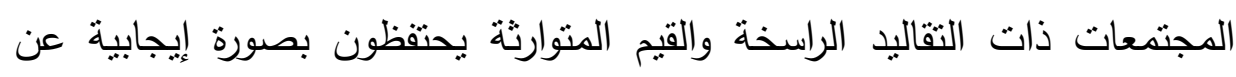

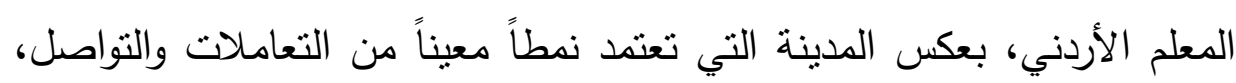


ב أ • عيسى محمد المراعية، د. . محمد أحمد حسن ريابعة عـــ

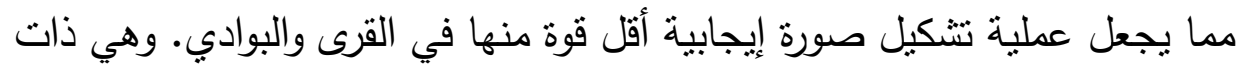
الحالة التي تتعلق بالمستوى العلمي، والتي تبين أن الفروق لصالح فئة (ثانوية

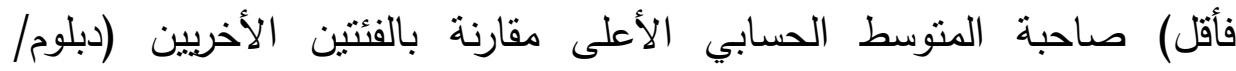
بكالوريوس) و (دراسات عليا)، بمعنى أن هؤلاء ممن لم يكملوا دراستهم الجامعية

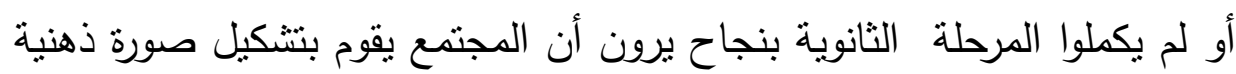

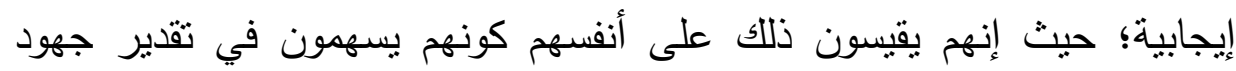
المعلمين الأردنيين أكثر من غيرهم من أصحاب المستوى العلمي الأعلى، وعند

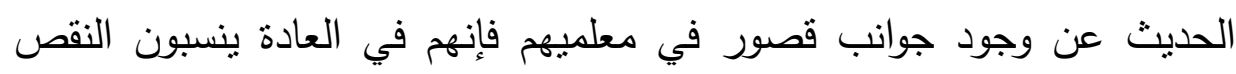

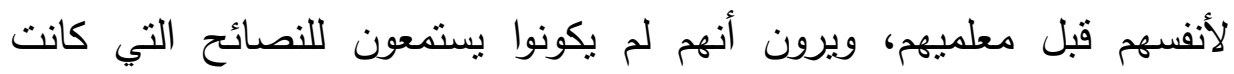

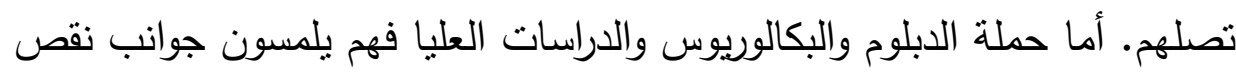

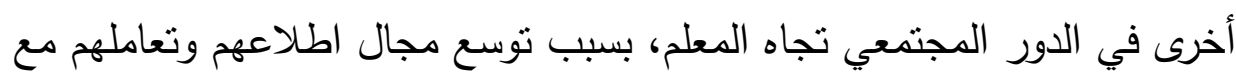
فئات متعددة من المجتمع وخصوصاً اختلاطهم بأساتذة الجامعات مما بترك أثنراً في تقيمهم للمعلمين في الددارس، ويكون له دور في طبيعة الصورة التي برون أن المجتمع يمكن أن يشكلها عن المعلم. ثانياً: مناقثة النتائج المتعلقة بدور المجتمع المحلي في تثكيل الصورة الذهنية

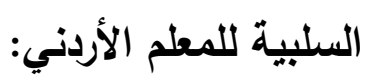

من خلال النتائج التي تم عرضها في الفصل الستباتيق فقد تراوحت الفقرات

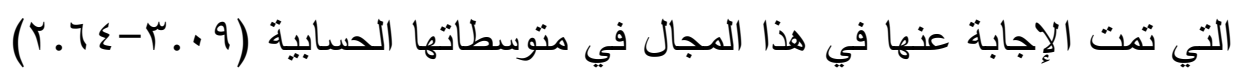

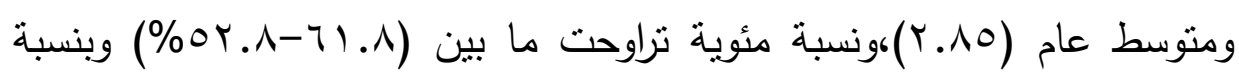

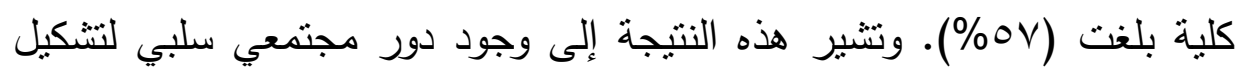

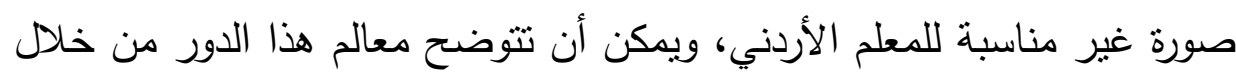

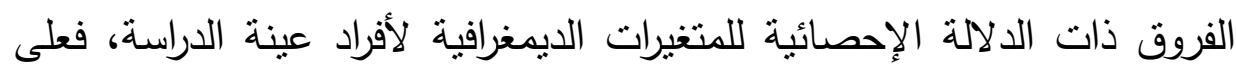

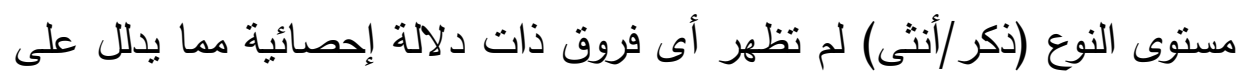

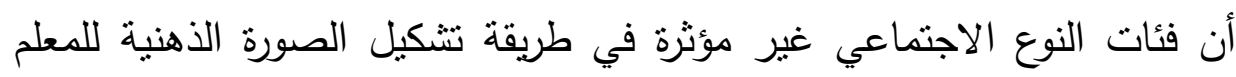




\section{الصورة الأنية للمعلم}

إيجاباً أو سلباً. بينما متغير العمر فقد تبين وجود فروق ذات دلالة إحصائية

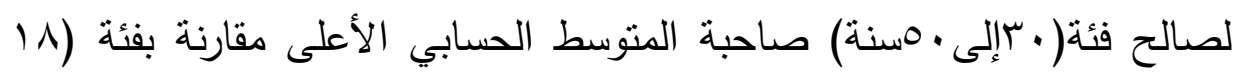

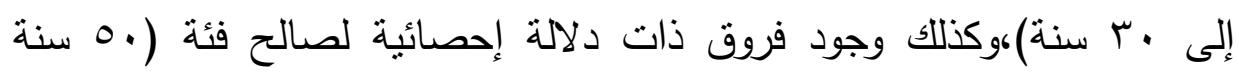

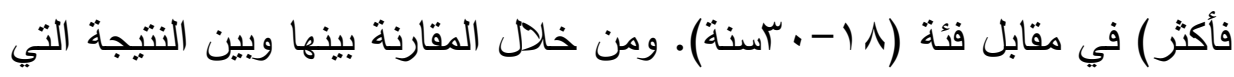

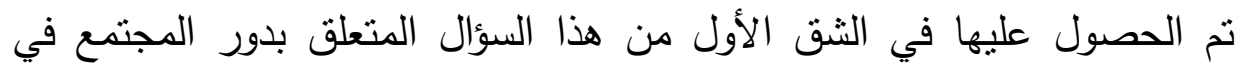

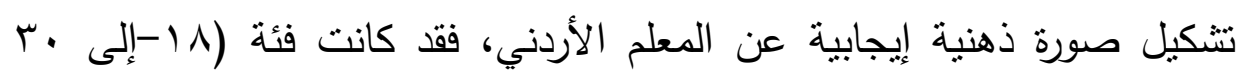

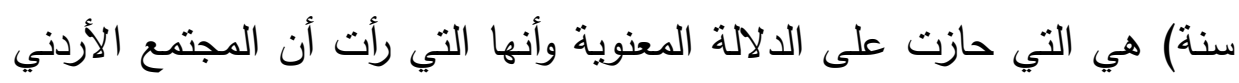

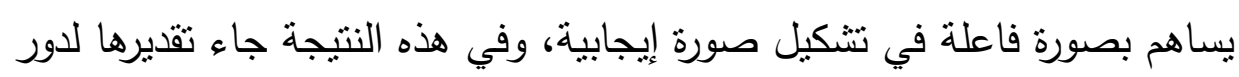

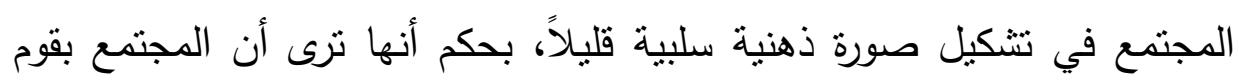

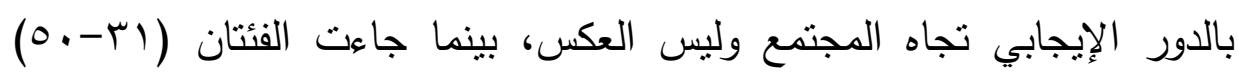

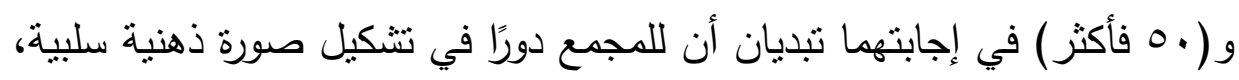
وذللك بحكم الاطلاع الأوسع لهذه الفئة والاختلاط الأكثر مع المجمع العام أولاً ثم لثم

$$
\text { مع مجتمع المعلمين في المدارس. }
$$

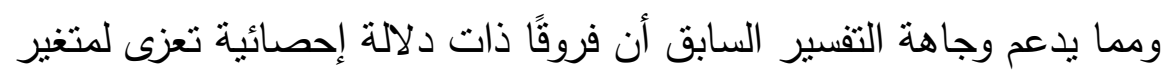

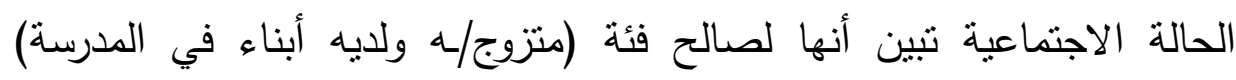

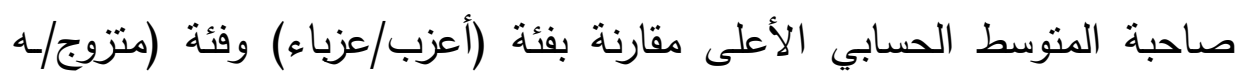

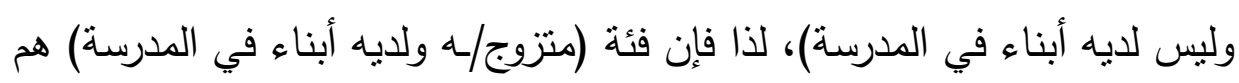

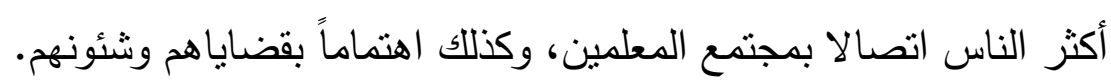
وبالنظر إلى مكان السكن الذي رأى أفراد العينة فيه من فئة (مدينة) أن الن النيان

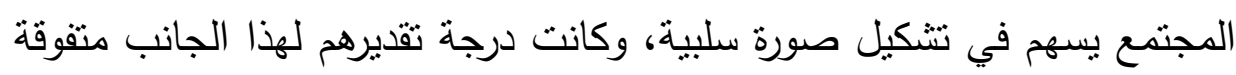
على درجة تقدير فئة (قرية/ريف) وفئة (بادية)، حيث إن أصحاب هاتين الفئنين

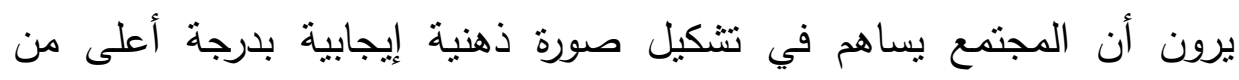

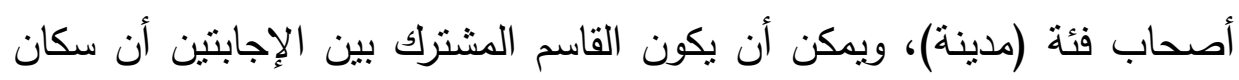




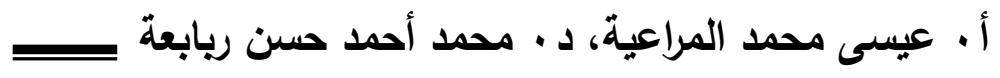

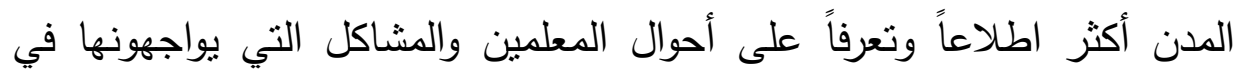

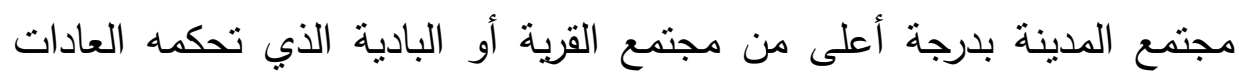

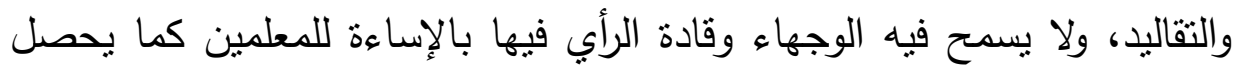

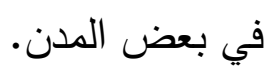

وقد نبين كذلك أن فئة المستوى العلمي (دبلوم/ بكالوريوس) وفئة (دراسات

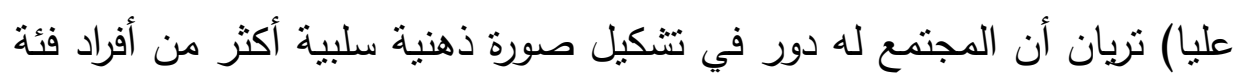

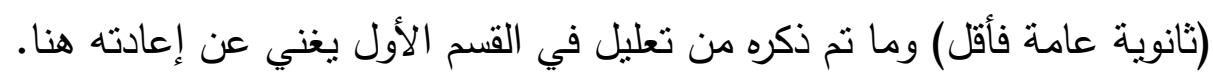

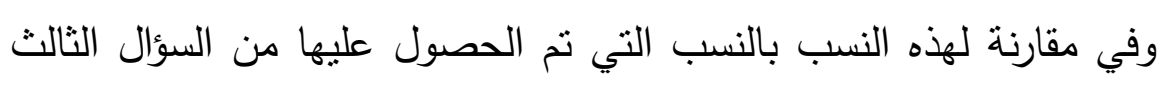

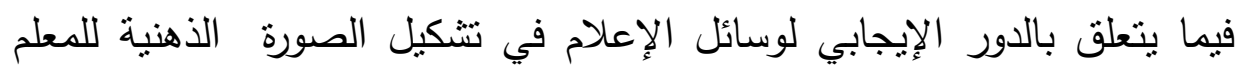

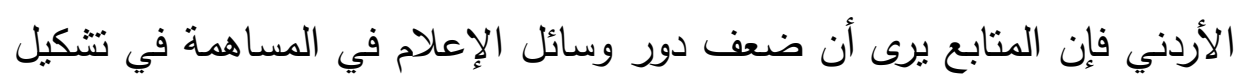

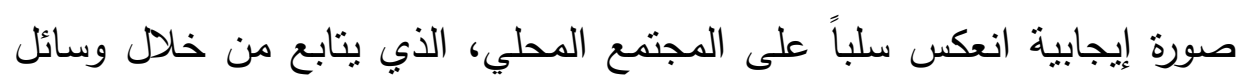

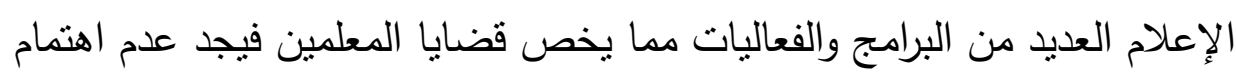

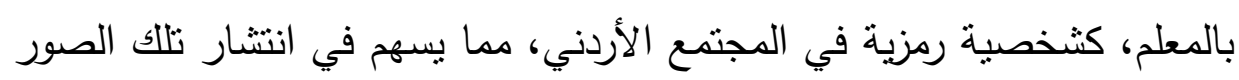

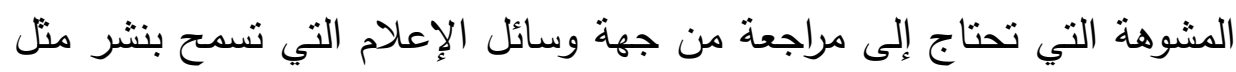

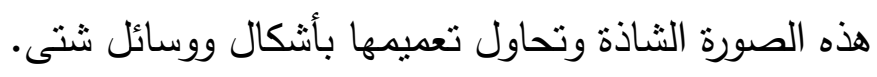




\section{حلية الصورة الذهنية للمعلم

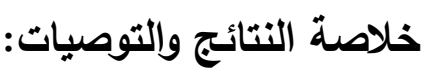 \\ أولاً: النتائج:}

من خلال مناقتنة النتائج تبين ما يلي:

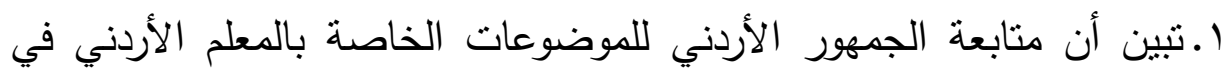

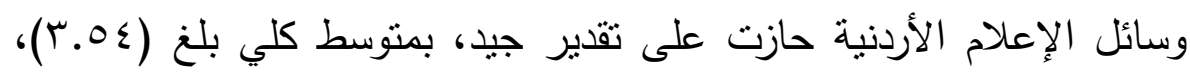

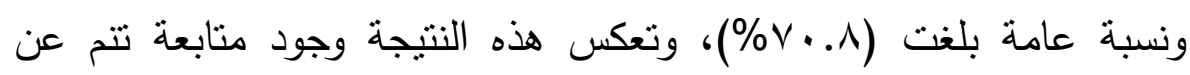

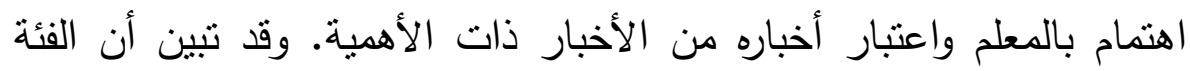

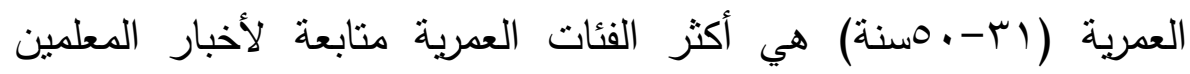

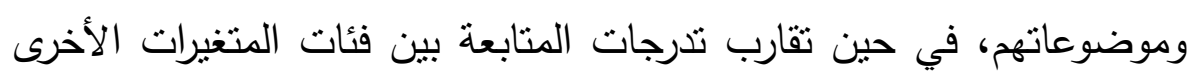

$$
\text { ولم يظهر فيها أي فروق ذات دلالة إحصائية. }
$$

r.تبين أن الصورة الذهنية العامة التي يحملها الجمهور الأردني للمعلم الأردني

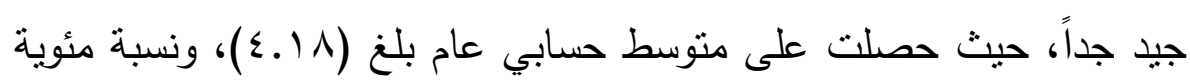

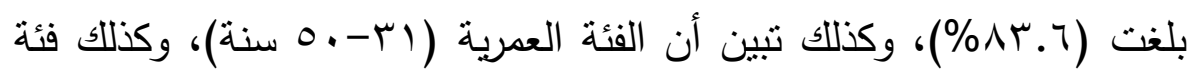
(دبلوم/بكالوريوس) من المستوى العلمي؛ تقدران المعلم بصورة أكثر من غيرها من الفئات الأخرى.

r. إن الدور الذي تقوم به وسائل الإعلام تجاه تتكيل صورة ذهنية إيجابية لم ينل رضا أفراد عينة الدراسة من الفئات التي تعود للمتغيرات الديمغرافية، فلم التهاه

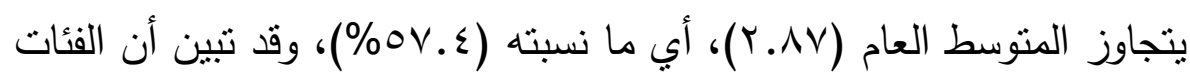

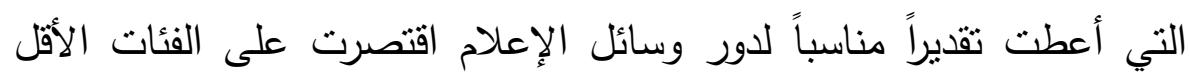

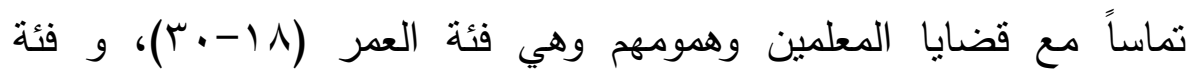

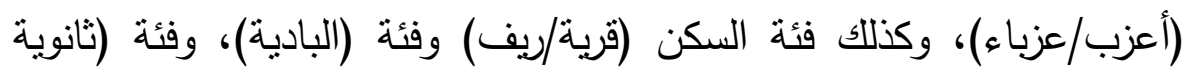

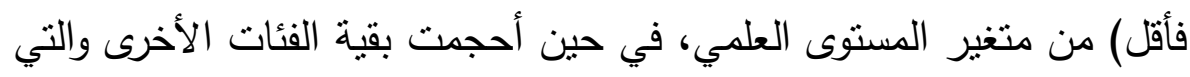
تُعد الأكثر متابعة لشئون المعلمين، وقضاياهم عن منح وسائل الإعلام تقديراً 


\section{أ · عيسى محمد المراعية، دـ · محمد أحمد حسن ريابعة}

مناسباً في مقابل الدور الذي تقوم به تجاه تشكيل الصورة الذهنية الإيجابية

$$
\text { لالمعلم الأردني. }
$$

ع.بينت النتائج أن دور وسائل الإعلام الأردني في تشكيل صورة ذهنية سلبية عن المعلم الأردني واضح المعالم، حيث حصلت فقرات هذا المجال على نسبة مئوية بلغت (79\%) وهي أعلى من النسبة التي حصل عليها الدور الإيجابي

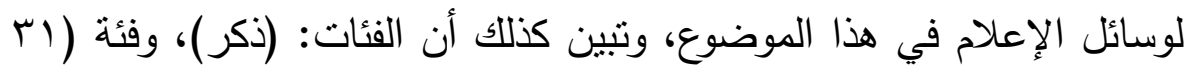

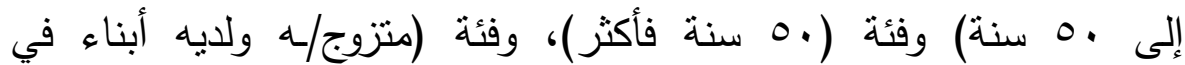
المدرسة)، وفئة السكن (مدينة)، وفئة (دبلوم بكالوريوس)، وفئة (دراسات عليا) صاحبة الاهتمام بقضايا المعلمين وموضوعاتهم هي التي كثفت حقيقة الدور السلبي الذي تقوم به وسائل الإعلام. وأن فئات المتغيرات التي كانت أقل معرفة بالدور السلبي الذي تلعبه وسائل الإعلام في تتكيل الصورة الذهنية

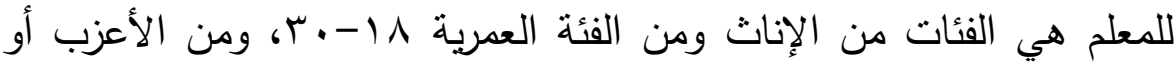

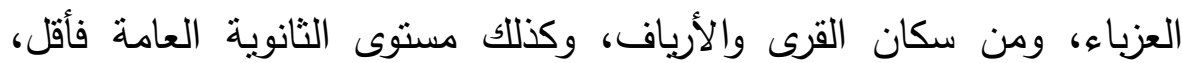

$$
\text { بعكس الفئات الأخرى. }
$$

0.بينت النتائج أن ما نسبته (70.7\%) من أفراد العينة يرون أن للمجتمع

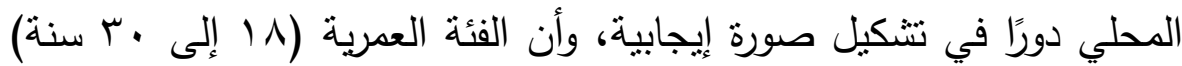
قد أعطت تقديراً لدور المجتمع في هذا الجانب بصورة أعلى من الفئتين الأخريين (ابإلى .0) و(0.0 فأكثر)، وكذلك فقد أعربت فئة (أعزب/عزباء)

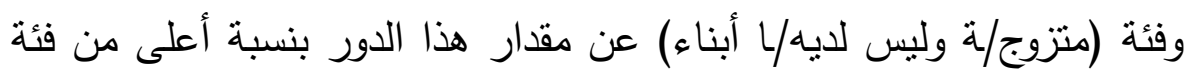
(متزوج/ة وله أبناء). وجاءت فئة مكان السكن (قرية/ريف) وكذلك فئة (بادية)

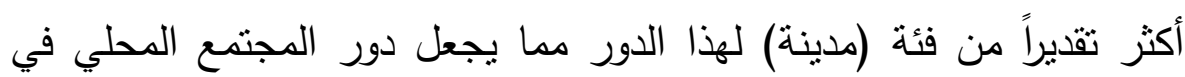

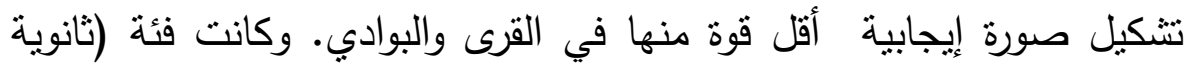

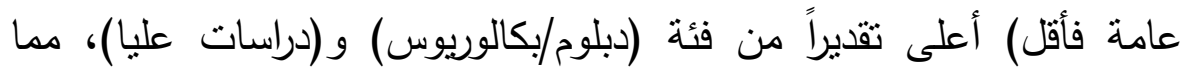
يوضح أثز المستوى العلمي في طريقة تقييم الأمور والحكم عليها. 


\section{الصورة الأهنية للمعلم}

7 ـاتضح من النتائج التي تم عرضها في الفصل الخامس أن نسبة تقييم أفراد العينة لدور المجتمع في تشكيل صورة ذهنية سلبية بلغت (ov\%). وتتشير هذه النتيجة إلى وجود دور مجتمعي سلبي لتشكيل صورة غير مناسبة للمعلم

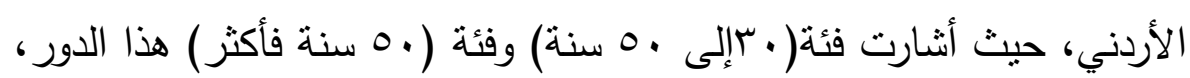
وبين كذلك أفراد عينة متغير الحالة الاجتماعية من فئة (متزوج/ة ولديه أبناء في المدرسة) هذا الأمر بدرجة أعلى من الفئتين الأخربين من نفس المتغير، وكان لمتغير مكان السكن فئة (مدينة) نفس الاتجاه، وظهر أن متغير المستوى لهی العلمي عند فئة (دبلوم/ بكالوريوس) وفئة (دراسات عليا) تؤكدان هذا.

ثانياً: التوصيات:

\section{خلصت الاراسة إلى جملة من التوصيات من أهمها:}

ا.أن تقوم وسائل الإعلام بتخصيص مساحة إعلامية أكبر عن المعلم، ويتم توظيفها لتشكيل صورة إيجابية تسهح في تعزيز دوره في المجتمع وتزيد من قدرته على الاضطلاع بالمهام والمسئوليات الملقاة على عاتقه. r.أن ثقوم وسائل الإعلام الأردني بمراجعة ذاتية لمواقفها تجاه المعلم الأردني، ومحاولة تقديم مواد برامجية ومسلسلات ومضامين تسهم في تشكيل صورة إعلامية إيجابية بدل الصورة السلبية التي تحاول رسمها من خلال ما تقدمه من مواد خلال السنوات السابقة بصورة مباشرة وغير مباشرة.

r.تتولى مؤسسات المجتمع المحلي بالتشارك مع وزارة التربية والتعليم القيام بحملات توعية حقيقية لدور المعلم، وبيان الصعوبات التي تواجهه في الميدان وحجم المعوقات التي تعترضه. 


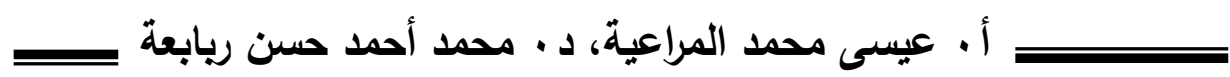

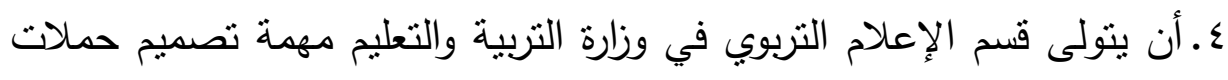

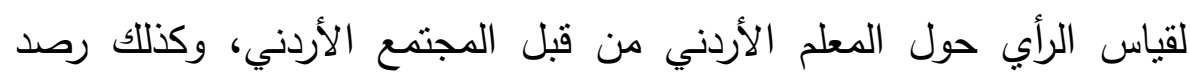
الثنائعات والأخبار الكاذبة ومتابعتها وتفنيدها.

ه. القيام بدراسة تفسر أثز وسائل الإعلام في تشكيل الصورة الذهنية السلبية عن المعلم الأردني لدى المجتمع المحلي الأردني. 


\section{=}

\section{قائمة المصادر والمراجع}

ا. ابن عاشور، محمد الطاهر بن محمد(؟19 1) التحرير والتتوير ، الدار التونسية

$$
\text { لبنشر ، تونس. }
$$

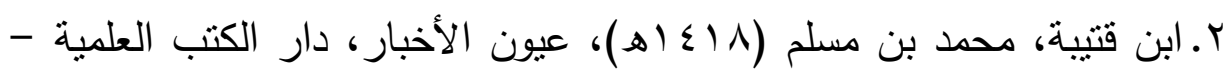

$$
\text { بيروت }
$$

r.ابن ماجه، أبو عبد الله محمد بن يزيد القزويني (د.ت )، سنن ابن ماجه،

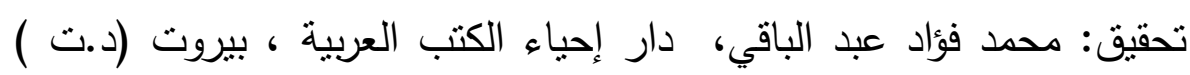

$$
\text { دار الكتاب ، بيروت. }
$$

ع. أمبوسعيدي، عبد الله والفهدي، والهاشمي راثند بن سليمان ، والرواحي عبد الها

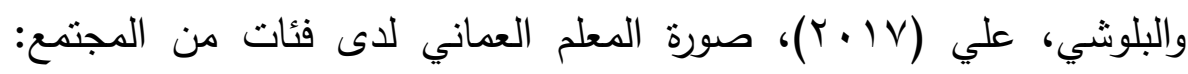
دراسة وصفية تحليلية، مجلة الدراسات التربوية والنفسية، جامعة قابوس، مجلد

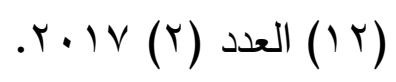

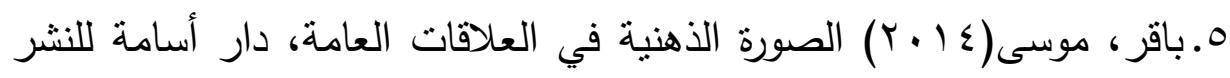

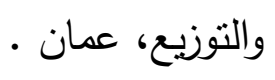

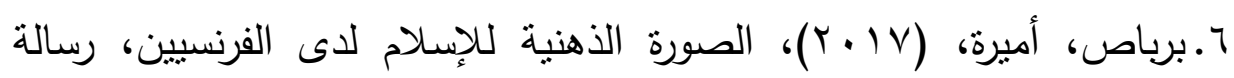

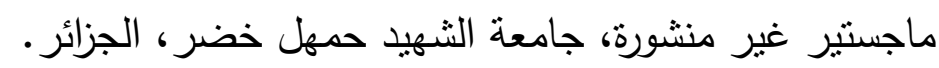

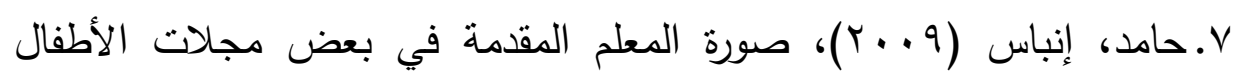
وعلاقتها بالصورة الذهنية لدى الطفل: دراسة ميدانية، مجلة دراسات الطفولة،

$$
\text { A } 9
$$

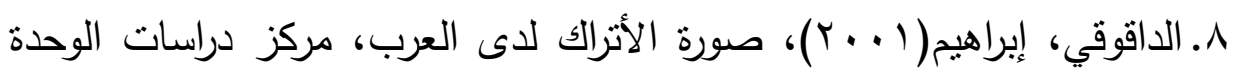

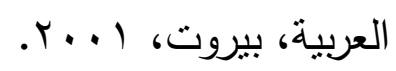




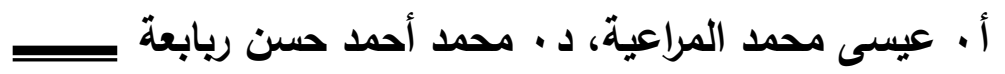

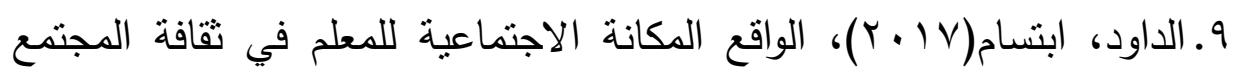

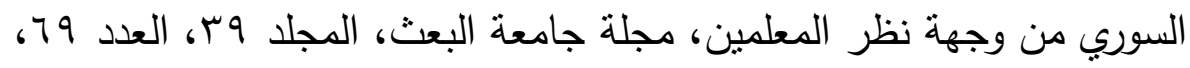

• 1. دخان، سارة، (10 • (1)، صورة المعلم في المجتمع الجزائري دراسة ميدانية

بمنطقة سطيف، رسالة ماجستير غير منشورة، جامعة محمد لمين دباغين.

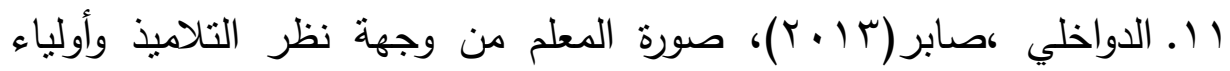

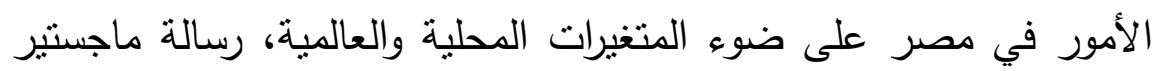

غير منشورة، معهد الدراسات والبحوث النزبوية، مصر .

rا. الزخشري، أبو القاسم محمود بن عمرو بن أحمد، الكثاف عن حقائق

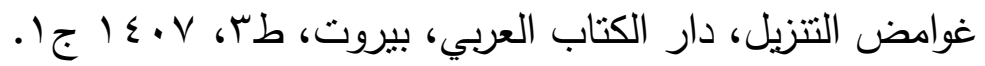

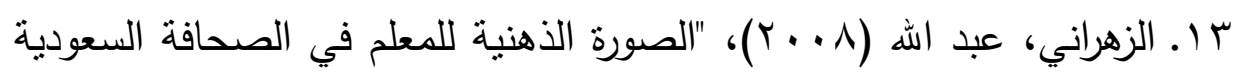

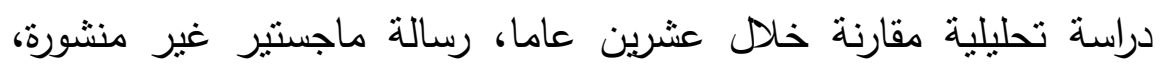

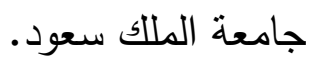

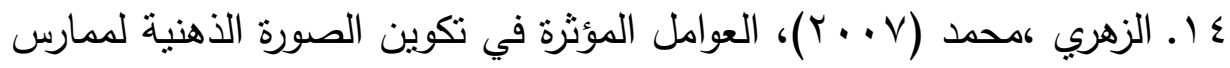

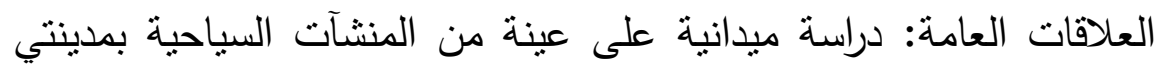

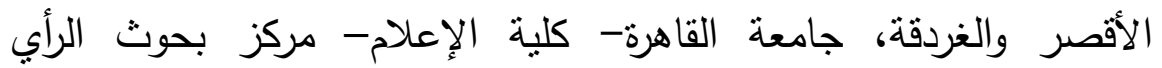

$$
\text { العام،V +. r. مجمع (^)، العدد (1) (1). }
$$

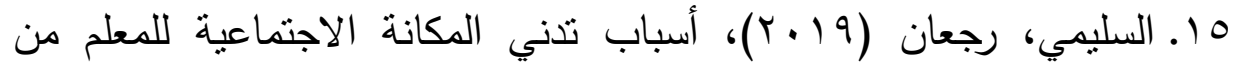

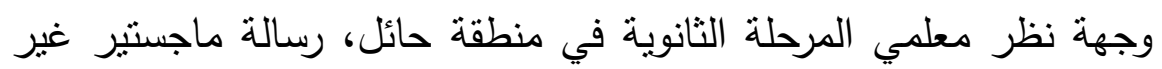

منشورة، جامعة حائل.

17 ـ شقرة، علي خليل، (10 ـ ب)، الإعلام والصورة النمطية، الطبعة الأولى، دار

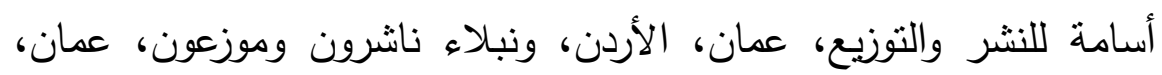




\section{سب الصورة الذهنية للمعلم}

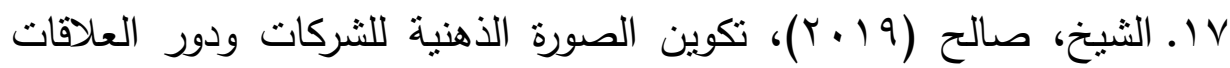

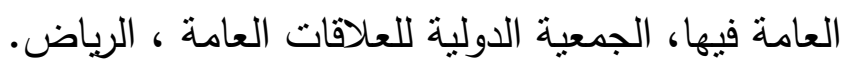

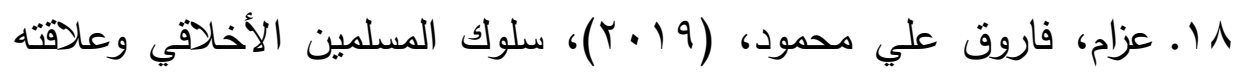

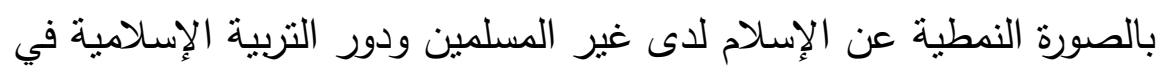

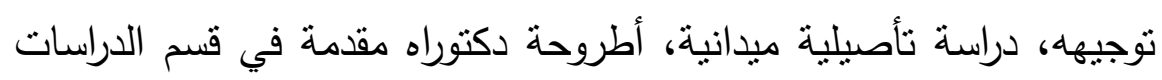
الإسلامية، كلية الثريعة، جامعة اليرموك، الأردن.

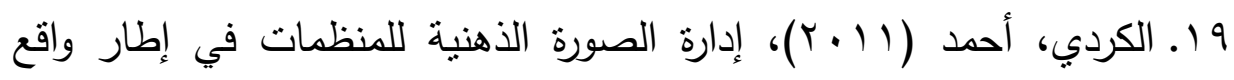

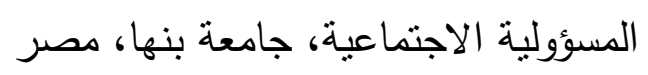

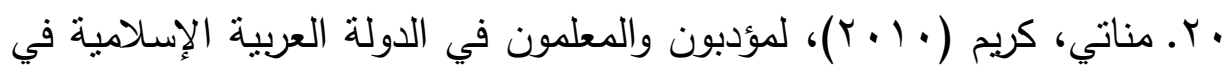

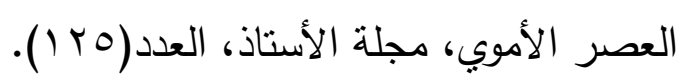

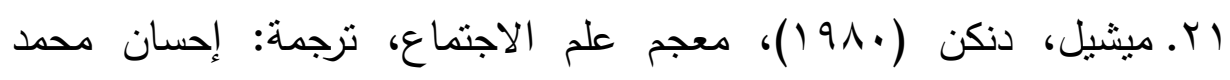

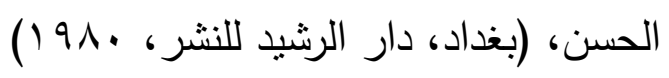

